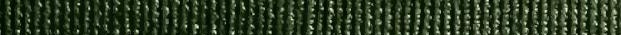

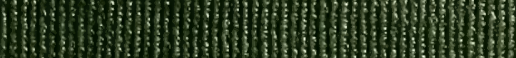

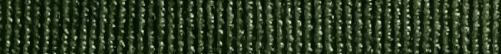

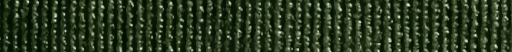
WHWhathow

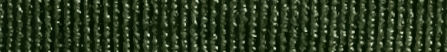

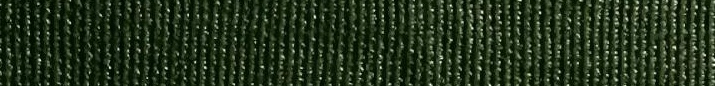

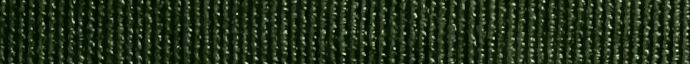

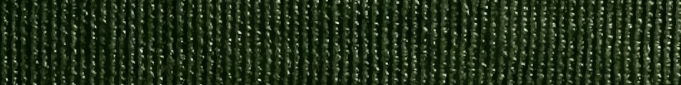

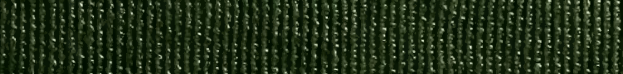

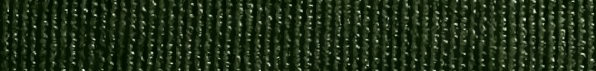

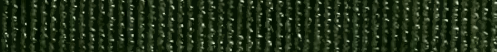

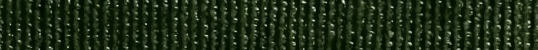

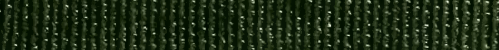

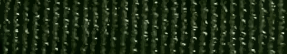
Hof (S): HaHe H:Pa? (1)

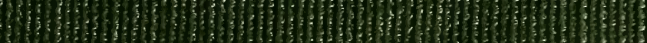

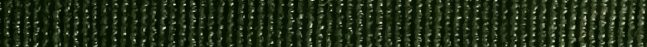

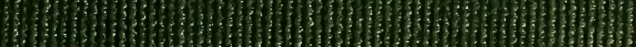

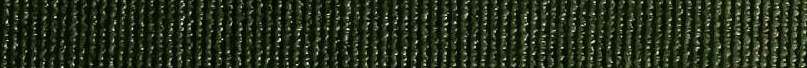

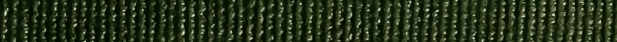

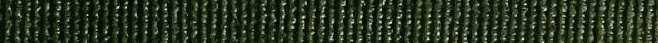

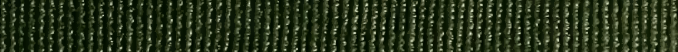

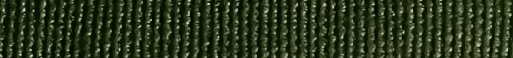

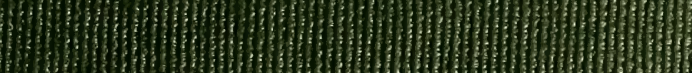

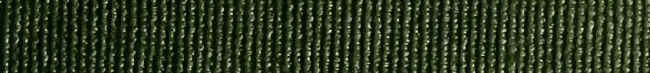

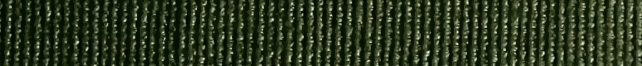

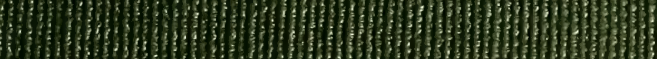

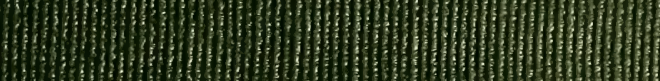




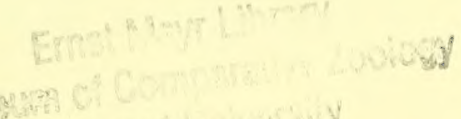
thanewd Unedidy 



\title{
ELEMENTS OF CONCHOLOGY,
}

INCLUDING

\section{THE FOSSIL GENERA}

\author{
A. N
}

\section{THE ANIMALS.}

\section{By T. EDWARD BOWDICH, EsQ.}

HONORARY MEMBER OF THE CAMERIDGE PHILOSOPHICAL SOCIETY AND OF THE WETTERAVIAN SOCIETY OF HANAU. MEMBER OF THE GEOGRAPHICAL SOCIETY OF PARIS. CONDUCTOR OF THE MISSION TO ASHANTEE.

\section{PART I. UNIVALVES.}

WITH UPWARDS OF 5ூ00 FIGURES.

\section{PARIS,}

\author{
PRINTED BY J. SMITH,
}

AND SOLD BY TREUTTEL AND WÜRTZ, SOHO-SQUARE, LONDON.

$$
\begin{aligned}
& \text { Feb. } \overline{1822 .} \\
& \text { (Price Twenty Shillings.) }
\end{aligned}
$$




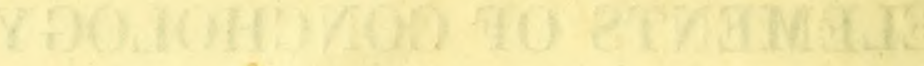

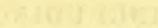

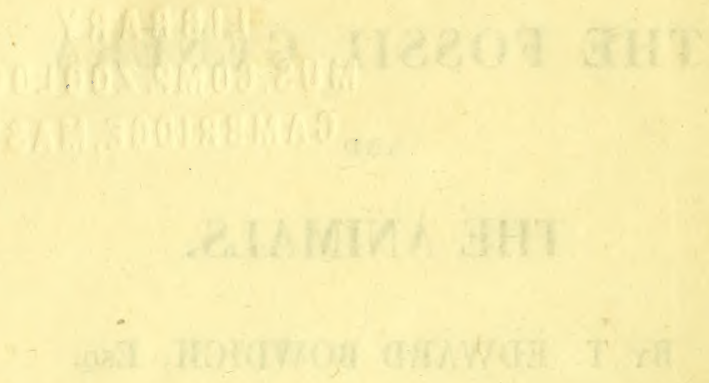

That

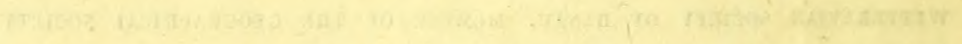

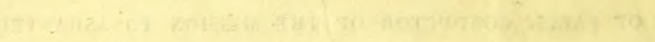

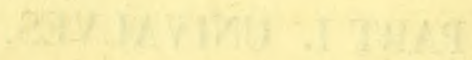

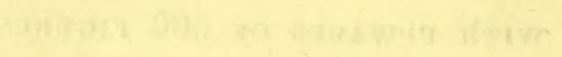

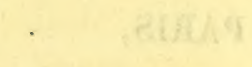

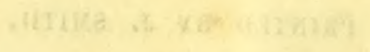

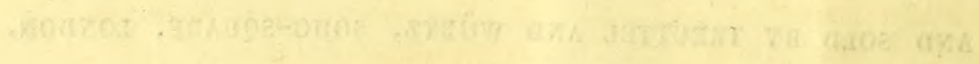

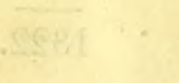

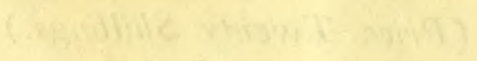




\section{P R E F A CE.}

ververeverve

$\mathrm{T}$

HIs Manual, like those of the Mammalia and the Orni-o thology already published, originated in the notes and drawings collected during a study of the subject, preparatory to a second travel in Africa. I had intended to arrange the similar materials for the publication of the Reptiles and Fish before the Mollusca, until a further progress in the study of Geology convinced me that the present Manual was not wanting to the Zoologist alone.

M. Brongniart has shown that the Formations containing the remains of marine shells, very rarely, and then under peculiar and evident local causes, present those of freshwater shells; and that the contrary had been alleged, because Genera containing both marine and fresh-Twater shells, differing not merely in specific but in generic characters, had not been reformed or subdivided. M. Lamarck acknowledged the justice of the observation, and resumed his labours, which had previously advanced this branch of Natural History considerably towards perfection, by establishing separations of marine, fresh-water, and terrestrial shells; but, unfortunately, his Extrait du Cours de Zoologie, published in 1812, contains the mere outline of his system, without the descriptions of the genera; and the lst and only part (which appeared two years ago) of the 6 th volume of his Histoire Naturelle des Animaux sans $V$ ertebres, without figures, contains merely the three or four first genera of the Univalves, and reminds us so frequently of the melancholy affliction which has now compelled this illustrious Naturalist to depend entirely on the eye-sight of others, that the appearance of the remain- 
ing parts, if they should appear, must be hailed by the friends of science with much less confidence, although with equal admiration and gratitude.

The system of classification desirable to the Geologist, is that by which a shell may be readily and accurately determined, without considering the animal which has inhabited it. Such a system is equally convenient to the Conchologist, when each genus is followed by a reference to the place which the animal occupies in the Natural System, which should always be adjoined. To be unable to determine the shell, unless we found the animal, would be like having no other aid than Crystallography for the study of Minerals.

These elements are principally compiled from Cuvier's "Mémoires pour servir à l'Histoire et à l'Anatomie des Mollusques," and the $2 \mathrm{~d}$ vol. of the "Règne Animal" of the same author; M. Lamarck's Mémoires sur les Fossiles des Environs de Paris;" M. Brongniart's "Mémoires sur des Terrains qui paroissent avoir été formés sous l'Eau Douce," and others on the same subjects, scattered through the 22 quarto volumes of the "Annales du Museum;" M. Blainville's and M. Defrance's articles in the "Dictionnaire des Sciences Naturelles;" M. de Ferussac's "Histoire Naturelle, générale et particulière, des Mollusques Terrestres et Fluviatiles;" and many other rare and costly wirhs, collected in the splendid library of Baron Guvier, to which I have had access at all hours, with the liberty of taking lome whatever I pleased, for the last two years.

The figures which illustrate the system of M. de Ferussac have been copied from those which accompany his work, with the exception of such as were to be found in the Museum. Almost all the other figures of the recent, and some few of the fossil shells, have been drawn from the objecls themselves; which I liave invariably been permitted to take home from the Museum for that purpose, without being limited either to time or number. I have occasionally been favoured with such specimens as were not to be found there, from the eabinets of MM. Lamarck. and Dufresne. 
The remaining part will contain the Bivalves, Multivalves, and the Sub-Coronalia and Vermicularia of Lamarck (the Brachiopoda and Tubicole of Cuvier) : a figure of the entire shell, of each valve, and of the hinges and teeth, when at all complicated, will be given. The Animals and Fossil Genera will also be included.

I beg to repeat that this Manual, as well as the others, has been compiled for those of my countrymen, whose remote situations in our colonies do not permit of their acquiring so desirable a species of knowledge, by the study of collections; as well as for those who, like myself, may cultivate Natural History, as the most agreeable delassement to mathematical studies.

Paris, November \&, 1821. 


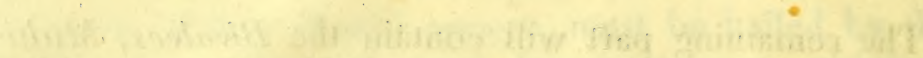

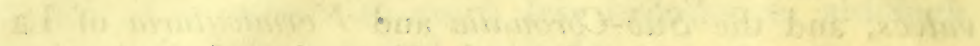

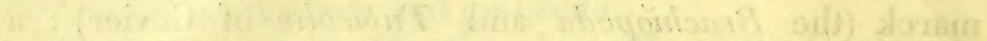

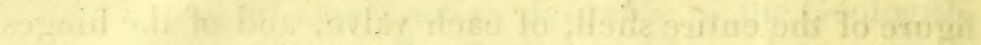

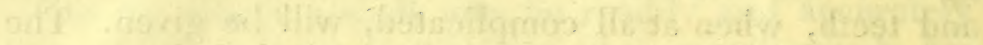

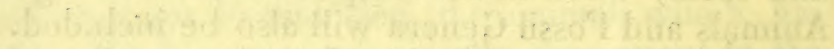

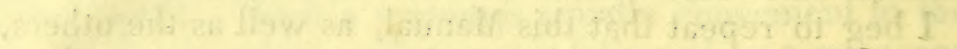

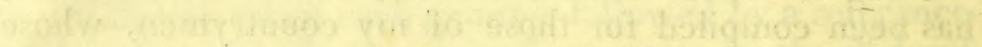

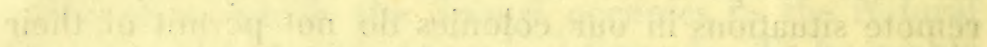
7.

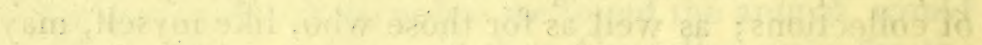

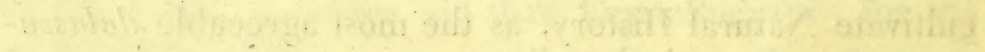

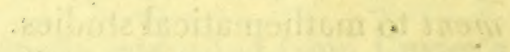

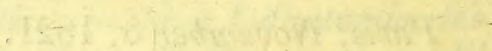
- 


\section{INTRODUCTION.}

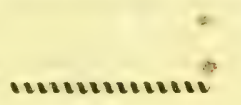

F

ossis shells, being nocessarily without brilliance, colours, or beauty, and frequently imperfecl, wore formerly rejected from collections as destituie of interest; but since it has been observed that these fossils are precious monuments for the study of the revolutions undergone by different points on the surface of the globe, they have become objects of the greatest interest to the Naturalist (1).

It appear's to have been proved that the shells, testuccous vermicularia, echini, and different species of polypi which are found so profusely in the fossil state beneath the soil or on its surface, even in the middle of continents and on the highest mountains (2), are the remains of multitudes of marine animals which lived in these places, and that several of the species are analogous to those now inhabiting the seas (5). For, as the quantity of these remains is enormous, since we know of masses nearly a hundred miles in extent, and as shells of an extreme thinness and fragility are found entire amongst them, we cannol but conclude that their animals have roally lived in these parts of the globe, and, consequently, that the sea has formerly been stationary there (').

(1) Conchology, when rendered subservient to goognostic investigations. assumes the rank of an useful science, and then becomes a subject of the highest importance. Bulimus trifasciatus, a very common West Indian shell, occurs imbedded in the same limestone which incloses the fossil human skeleton, lately sent to the British Museum, from the grande terre of Guadaloupe, by Sir A. Cochrane, proving that rock to be of modern date, and contemporameous with the existing creation of animals. Leach's Zoological Miscellany. Vol. i, p. 42.

(2) According to Ulloa, shells have been found at the height of 11,220 fect above the sea, ou a mountain in Peru.

(3) M. Defrance has discovered at least 500 species of fossil shells in the calcaire grossier at Grignon, the equivalent of the London clay.

(1) Les terrains les plus bas, les plus unis, excavés jusqu'a de tris-grandes profondeurs, ne montrent que des conches horizontales de matières variées, enveloppant presque toules dimnombrables produits de la mer. Des couches 
The shells whose analogous species do not live in our seas, but in those of warm climates, form a part of the fossils found in the north of Europe. The Nautilus Pompilius found at Courtagnon, and the remains of which are not uncommon at Grignon, is one of the

pareilles, des produits semblables, composent les collines jusqu'aux plus grandes hauteurs. Quelquefois les coquilles sont si nombrenses, qu'elles forment à elles seules toute la masse du sol. Presque partout elles sont si bien conservées, que les plus petites d'entre elles gardent leurs parties les plus délicates, leurs crêtes les plus subtiles, leurs pointes les plus déliées. Elles s'élèvent à des hauteurs supérieures au niveau de toutes les mers, et où nulle mer ne pourroit être portée aujourd'hui par des causes existantes. Elles ne sont pas seulement enveloppées dans des sables mobiles, mais les pierres les plus dures les incrustent souvent et en sont pénétrées de toute part. Toutes les parties du monde, tous les hémisphères, tous les continens, toutes les îles um peu considérables présentent le même phénomène. On est donc bientôt disposé à croire, non seulcment que la mer a envahi toutes nos plaines, mais qu'elle y a séjourné longtemps et paisiblement pour y former des dépôts si ćtendus, si épais, en partic si solides, et contenant des dépouilles si bien conservées. Le temps n'est plus ou l'ignorance pouvoit soutenir que ces restes de corps organisés étoient de simples jeux de la nature, des produits conçus dans le sein de la terre par ses forces créatrices. Une comparaison scrupuleuse de leurs formes, de leur tissu, souvent même de leur composition chinique, ne montre pas la moindre différence entre ces coquilles et celles que la mer nouryit; elles ont done vécu dans la mer; clles ont été déposées par la mer : la mer existoit donc dans les lieux où elle les a laissées; le bassin des mers a donc éprouvé au moins un changement, soit en étendue, soit en situation. Voilà ce qui résulte déjà des premières fouilles, et de l'observation la plus superficielle.

Les traces de révolutions deviennent plus imposantes quand on s'élève un peu plus haut, quand on se rapproche davantage du pied des grandes chaînes.

Il y a bien encore des bancs coquilliers; on en apercoit même de plus épais, de plus solitles: les coquilles y sont tout aissi nombrenses, tout aussi bien conservée; mais ce ne sont plus les mêmes espèces; les couches qui les contiennent ne sont plus ausoi génćralement horizontales. Elles se redressent obliquement, quelquefois presque vexticalement. Au lieu que, dans les plaines et les collines plates, il falloit crenser prufundenten pư connoître la sucression des banes, on les voit ici par leur flaac, en suivant les vallées produites par leurs déchiremens. D'immenses amas de leurs débris forment au pied de feurs escarpemens des collines arrondies, dont chaque dégel ct chaque orage augmentent la hauteur.

Et ces banes redressés, qui forment les crètes des montagnes secondaires, ne sont pas posés sur les bancs horizontaux des collines qui leur servent de premiers échelons; ils s'enfoncent au contraire sous cux. Ces collines sont appuyées sur leurs penites. Quand on perce les couches horizontales dans le voisinage des conches obliqués, on retrouve celles-ci dans la profondeur : quelquefois mème, quand les conches obliques ne sont pas trop élevées, leur fommet est couronné par des couches horizontales. Les couches obliqques sont done plus anciennes que les couches horizontales; et, comme il est impossible 'fu'ellés n’aient pas été formées horizontalement, il est évident qu'elles ont été relevées, qu'elles l'ont été avant que les autres s'appuyassent sur elles.

Ainsi la mer, avant de former les couches horizontales, en avoil formé d'autres, quiune rause quelconque anvit brisées, redicssées, bonleversées de mille manicies. Il y a donc eu aussi iut moins un changenent dans le sein de 
numerous instances (1). The fragments of palm-trees; the fossil masses of gum-elastic; the impressions of exotic ferns in slate and coal; and the fossil bones of the Elephant, Crocodile, etc. found in England, France, Germany, and other parts of Europe, seem to altest a mutation of climate (2).

Cuvier and Brongniart were the first who announced the existence of formations, anterior to history, composed in the same manner and presenting the same characters, although situated at great distances from each other, and containing Terrestial and Fresh- $W$ atcr instead of Marine produclions (J). It is impossible to arnit the hypothesis of the transport of these terrestrial productions to the sea by means of rivers. They might have carried into the sea some remains of vegetables and some fluviatick and terrestrial shells, but then the formations irhich are composed of them ought

celte mer qui avoit précédé la nótre; elle a éprouvé aussi au moins une catastrophe; et comme plusicurs de ces banes obliques qu'elle aroit formés les premici’s s'élèvent au-dessus de ces couches horizontales qui leur ont succédé, et qui les cntourent, cette catastrophe, en rendant ces hancs obliques, les avoit aussi fait saillir au-dessus du nireau de la mer, et en avoit fait des îles, ou au nuins des écucils ct des inégalités, soit qu'ils cusseni été relerés par unc cxtrémité, ou que l'affaissement de l'extrémité opposéc eût fait baisser les caux; second résultat non moins clair, non moins demontré que le premicr, pour quiconque se domnera la peine d'étudier les monumens qui l'appuient.Cuvier, Discours sur la Théorie de la Terre. Paris, 1821.

(1) See the note on that singular shell the Trochus agglutinans, p. 35.

The Terebellum perditum (the analogous living species of which is not known) is found in great numbers and of all ages at Grignon. which M. Lamarck considers wonld not have been the case unless the enormous quantity of marine shells had lived in that region, instead of being arrmmintard there by some great catastrophe. At Courtagnon, near flicims, an enormous bed of fossil shells discovers itself in several points; it procects from east to mest. appears agam at Frignon and some other places, and firom M. Lamarck's comparison of the species with those found in Hampshire appears to have extended to that part of England. If so, there is reason to believe that this bed has been dirided by the Chamel since its formation: and, conseguently, lhat its formation was anterior to the last invasion of the sea.

(2) The rocks of the western coasts of France are interlarded with Gryphites, Ammonites and other shells (coquilles pelagiennes) known to inhabit the sea only at great depths. Recent littoral shells have been found fixed on these fossil deep-water shells, which are also common in the hills called VachesNoires. There is a pottery in that neighbourhood which is supplied with clay from that part of the beach which is uncovered at low water; this clay, whicht is said to be very superior, contains quantities of deep-water fossil shells. It would seem, therefore, that these parts are not now subjected to the sea for the first time. Again, the fossil marme shells found more than 60 feet deep in the earth, probably were not deposited during the last invasion or passage of the sea.-Hy drogeologie, par J. B. Lamarck. Pages 85, S6.

(i) Lamanon is said to have ofserved immense beds of fresh-water shell; on beds of marine shells in lie mountaius of Provence. 
to present the forms and all the characters of alluvium; that is to say, a mixture of all sorts of heterogeneous matters, more fragments than entire bodies, coarse sands, unequal and irręgular strata. We find nothing of this kind in the Fresh-WTater Formations; the limestone is almost pure, every thing is in its place and perfectly cntire, the most delicate shells present themselves in complete preservation; indeed, fragments of them are scarcely to be found in this formation, whilst, in the marine, fragments are met with in large quantities. W'e must, therefore, suppose a great tranquillity in the waters wherein these shells have lived. They are deposited in beds, often rery thin and perfectly horizontal, like the masses of limestone and the zones of silex which they contain; the silex is in beds, frequently continuous, and never in rolled pieces. The disengagements of gas, indicated by the tubulures, have almost always been made rertically, and have often proceeded from the same plane, which is a further proof of the tranquillity of the liquid and the homogeneity of the Formation. Lastly, the immense extent of these deposits, which occupy spaces of more than 1200 square leagues, and which in so great a surface do not present any trace of disorder, renders this hypothesis perfectly admissible (1).

The extent of these masses of Fresh-Water Formation oucht not to astonish us; we know of others at least as vast in North linerica. If the lakes Superior, Michigan, Huron, Erie, and Ontario depositer stony layers on their beds and became dry, they would leave Fresh-Water Formations more extensive than any of those just described (2).

Among the different stages of alteration in which we find fossil shells, the most frequent is that in which only the animal part has

(1) M. Brongniart remarks that marine aurl fresh-water shells liave in no instance been found mixed together, except in the quarries of Gris at Beauchamp near Pierrelaie, where the cause is local; for the fresh-water limestone, which forms the surface of the soil, reposes immediately on the marine sand which forms the bed or fond; the mixture of the two, therefore, in this point of contact is natural. .I. Defrance has since adduced and explained another instance; see note on the Genus Helix. At Montmartre the Calcaire Marin forms a kind of manelon or small hummock, and the gypsum in depositing itself on these beds, which are posous and friable, has enveloped the marine shells which they contain. Indeed, there is no proof that gypsum may not be a salt-water deposit; the upper marine formation contains small beds of gypsum at intervals, and the oysters are often covered with chrystals of selenite. There are only 3 fresh-mater genera of biralve shells, and it is remarkable that no species of either has been found in the Fresh Water Formation.

(2) Fresh-water deposits nust not he determined by the presence of doubtfil shells, but, like that of the cuvirons of Paris, on the constant presence of a consilerable majority of shells not found elsewhere; and on the constant absence of all marine bodics. See Pl. 1 
been destroyed, that is to say, the gelatinous or membraneous portion which is mixed with the cretaceous part; so that after its destruction the shell is almost exclusirely composed of calcareous matter. It has lost its brilliance, its colours, and often even its mother of pear, if it had any, for it owed all these to the presence of the animal part. It has generally become quite white, but sometimes, having been long buried in a slime containing coloured particles, it has acquired a peculiar hue, not its own. Other fossils have not only lost the animal part, but even their substance has been transformed into siliceous matter; in this case, the closer approximation of the component parts leares a small roid space around the shell, in the stone wherein it is imbedded, more or less interrupted by lateral adherences. Shells have somelimes been so peculiarly disposed by volcanic eruptions, as to preserve their natural colours even in tho fossil state.

We scarcely condescend to examine microscopic shells, from their insignificant size; but when we reflect that it is by means of the smallest objects that Nature every where produces the most astonishing and remarkable phenomena, they become highly interesting, from their multiplication or abundance, and their consequent influence on the composition and extent of the masses composing the exterior crust of the globe. Whatever Nature may seem to lose in point of volume in the production of such bodies, is amply made up by the number of the individuals, which she multiplies with admirable promptitude to infinity. The remains of these minute animals, therefore, hare much more influence on the surface of the globe than those of Elephants, Hippopotami, or Whales. 



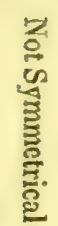

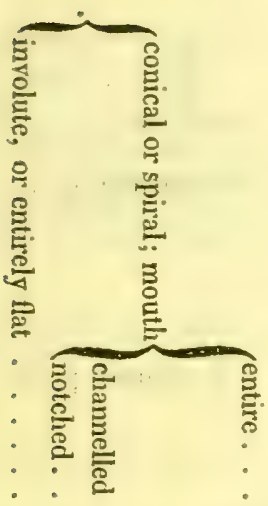




\section{(14)}

\section{DIVISION I. SEPIACE $\mathrm{E}$.}

\section{GENIRA.}

1. Loligo, Lam. Galmar.

A plate of horn on the V. Animal, p. 54. back, instead of a shell, in the form of a sword or lancet. PI. $1_{2}$ fig. 2.

\section{Sepia, Lam.}

Shell oval, thick, gibbous; composed of an infinity of very thin calcareous plates, parallel, joined together by innumerable little hollow columns. Pl. 1, fig. 1 (1).

(1) Being friable, from its structure, it is employed to polish various substances; it is also given to young birds to sharpen their beaks. 


\title{
DIVISION II. NUMMULACEE.
}

\author{
GENERA.
}

1. Numbula. Lam. CisMERIYA. Brug.

Exterior form lenticulas, without any apparent opening; a spiral cavity divided by septa into an infinity of small chambers (1).

a. Perfectly discous. Pl. 1, fig 3, 4. (2)

No siphon.

Marine.

Only one row of chambers to each turn of the spire.

The edge with blunt or sharp rays. Pl. 1, fig. 23.

Several rows of cham * bers to each turn of the spire.
Fossil and living.

Microseopic. b. (Siderolites, Lam.)

f. (Renulites, Lam.)

\section{Discorbites. (3) Lam.}

Spiral, all the turns visible and exposed. (4) Pl. 1. fig. 5 .

\section{No siphon.}

(1) The Nummulites are amongst the most widelynspread fossils, forming, at most exclusirely, entire chains of calcareous hills and immense beds of building stone. The Pierre de Laon is composed of Nummulites; the pyramids of Egypt were constructed with stone of this nature, and are raised npon the rocks which supplied it. They were formerly considered, by some, to be Lusus Natura, by which portions of calcareous matter assumed the form of organised bodies; by others, as petrified seeds, opercula, bivalve shells, etc. etc. Breynius, in 1732, and Gesner, in 1758 , concluded them to be univalve shells, very analogous to the $\mathrm{Am}$ monits. Bruguiere thought that the animal was contained in the last chamber of the shell. Cuvier considers them to be interior shells. To observe the chambers more distinctly, let a drop of ink fall on the worn face, and when it is quite dry, rub the Nummulite delicately on a stone to take off the exterior black, after which all the points which have retained the ink become evident on a white ground, and the interior organization is perfectly discovered. This practice is useful for recognising several other delicate fossil shells.

(2) These are the most common and the largest amongst the fossil species, but the liring species are very small.

(3) The termination iles distinguishes the Gencra exclusively fossil, no analogous living species having been yet discovered.

(1) This character distinguishes them from the Spirolinites, the absence of the siphon from the Nautili. 


\section{(16)}

\section{DIVISION III. SPHERULACE IE.}

\section{GENERA.}

1. Mritola. Lam.

Oval, globulous, or oblong; subtrigonal; the spin ral turning around an axis perpendicular to the planes of the turns; divided into 2 or 3 chambers, the last pierced by a lateral hole, which is the only aperture. Pl. 1, fig. 6.

\section{Pollontes. Montf.}

Resembling the Miliola, but the chambers pierced alternately towards both ends of the shell, and the last open the whole breadth. Pl. 3, fig. 16.

3. Arethusa. Montf.

Chambers rolled obliquely (making the shell turreted) and only the last perforated. Pl. 3, fig. 17.

\section{Melonites. Lam.}

No apparent mouth; consisting of numerous tubes or siphons united in a plane rolled on itself. Pl. 2, fig. 1.

\section{Gyrogonites. Lam.}

Hollow spheroids, composed of several linear picces, curved, joined at the sides, the extremities terminating in the poles; the surface furrowed in transversal circles (2). Without chambers.
Marine. Some species found on Fuci, in the neighbourhood of $\mathrm{Cor}$ $\operatorname{sica}(1)$.
On the shores of the Mediterranean Sea and Indian Ocean.
Microscopic. On the shores of the Adriatic.
Scaltered throughout the masses of silex belonging to the First and Second Fresh Water Formation of the environs of Paris.

Pl. 1, fig. 14.

(1) The fossil species have formed, exclusively, immense beds of stone, especially in the quaries of the environs of Paris.

(2) Only one species known, the size of a pin's head, G, madicaginula, Lan?. 
DIVISION IV. ORTHOCERACET.

\section{GENERA.}

1. Beleminites. Boet. de Boot.

A thin double case, composed of two cones from the summit of the united at their bases; exterior to the same part the interior cone much of the interior cone, shorter than the other, whence it continues eidivided within by paral- ther along the edge or lel septa, concave towards through the centre of the the base; only one cham- septa.

ber (conical) apparent, the older ones being successively effaced by the piling up and contiguity of the septa. Pl.1, fig. 9, 22, etc.

a. Elongated in cylinders, sharpened at the end only.

b. Narrowed towards the base, like a distaff or lance.

2. Orthoceratites. Breynius.

Straight or slightly bent; chambered; margins of or 2 small undulations. Pl. 1, fig. 25. Pl. 2, fig. 11.

3. Conulárites. Miller.

Concave, hollow, mouth half closed by an inflexion of the lip. Pl.3, fig. 19, 21 .

Septa imperforate.

A siphon central or lateral.

Septa imperforate.

\section{Amplexites. Sowerby.}

Nearly cylindrical; divided into chambers by numerous transverse septa embracing each other with their reflected margins. Pl. 2, fig. 10.

\section{Nodosaria. Lam.}

Straight, chambered, slender, with a contraction at each septum.
Very abundant, especially in strata of Chalk and Compact Limestone.
Said to characterise the Transition Rocks of Werner.
In Transition Limestone, in Ironstone, in Schale, with marine shells.

In the Limestone of the Black Rock at Limerick.

\footnotetext{
Akin to the Raphanister (Pl.2, fig.15), Echidnus (Pl. 2, fig. 14), and Telebois (Pl. 3, fig. 22) of Montfort?
} 
a. Contractions moderate. Pl. 2, fig. 9.

$b$. Contractions sa deep that the septa are united by the siphon only and appear as if strung together. Pl.2, fig. 12.

\section{Hippurites. Lam. Coli-} NU-COPIE. Thomson.

Thick, cylindrical or conical, with irregular septa traversing two longituA siphon, a gutter in- Several large species dinal cylindrical projections adhering to one of the sides; mouth closed by an operculum. Pl. 1, fig. 21, 26, 28, 31,33. Pl. 2 , fig. 18 .

a.

Conical, more or less arched. Pl. 1, fig. 21.

b. Batholites, Montf. Straight, cylindrical.

\section{Bacuirites. Faujas. $\mathrm{H}_{\mathrm{A}-}$ Mites. Parkinson.}

Straight, cylindrical, a little conical, fusiform, hooked or bent, compressed : septa transverse, undulated at the margins. Pl. 1 , fig. $17,19$. Pl. 2, fig. 16, Pl. 3, fig. 18,23 .

\section{stead of a siphon, or both. in the older Secondary Mountains.}
$a$. With a siphon at the outer edge of the chambers.
b. Without

\section{Turrilites. Montf.}
Spiral, turreted; with Septa pierced in their chambers divided by si- disks. nuous septa: the turns contiguous, all visible : mouth round. Pl. 1, fig.

Maestricht. In the clay at Folkstone. In the chalk at Hamsey and at Horton. 16.

\section{Belemniles.}

According to M. Beudant, they have never been found in transition limestone, or srey wacke, but first appear in the arillaccous iron stone which alternates with bituminous slate. The internal of the two testaccous cones is filled with a solid substance, presenting either radiating fibres or conical beds enveloping each other, and their bases corresponding with the edges of the septa of the interior cone: this solid part is sometimes found alone; at others, the kernels of the chambers of the interior cone or the alveoli are also met with. Pl.1, fig.9. Most frequently the alveoli and the chambers themselves have left no other traces than some projecting circles within the interior cone; but we sometimes meet with the alveoli still piled on one another, but detached from the double conical case which envelopes them. The exterior cone has generally a notch on one side of the base continued in a longitudinal furrow. Klein, in 1734, was the first who considered the fusiform Bclemnitcs to be apincs of Echini, from the similar exterior form, and the radiation presented in 
both on fracture, 1'. 1, fig. 8. pl. 2, fig. 7 : it does not appear, however, that he thought of making a longitudinal section of the Echinus, such as M. Beudant has submitted, pl. 1, fig. 8. pl.2, fig.8. A Belemnite, in the collection of the Conseil des Mines, which has not entirely passed into the calcareous state, presents in some of its parts the same spongy and radiated tissue which we observe in the spines of the Echinus. This Bclemnitc also offers the peculiarity of a nipple at the base, with projecting sides, striated transversely, and diverging from the centre to the circumference; the centre is perforated by a small shallow round hole : the summit sometimes terminates in folds. Pl.1, fig. 10,11,12. Some present a large conical cavity at the base, which has been often considered as the last chamber or dwelling of the animal; others have none, or at least it very small cavity. Theophrastus's description of the lynx stone is not applicable to the Bctcmnite: it would seem that we owe the first notice of it to Pliny, but it is not quite clear whether his dactylus idaus (1. 37, c. 10) which he clearly distinguishes firom the lynx stone (1.8, c. 38) was a fossil species of Echinus or Bclemnitc. In the 15 th century they were considered to be meteoric stones, and marrellous medicinal virtues were ascribed to them. Boetius de Boot, in his Treatise on Stones, pronounces them to be petrified darts, and it was not until the end of the 16 th century that they were first regarded as natural organised bodies. Erhart, in 1724, appears to have been the first who concluded them to be shells akin to the Nautilus. Deluc insisted that the Belemnite was an organised bone, like that of the Sepia; and they have been concluded by other authors to be stalactites; petrified wood; the teeth or the back bones of fish; the tusks of the Narwal; Crocodile's teeth; tubulites, etc. etc. Curier, Rigne Animal, t. 2. p. 371. :are, Jour. de Phys. ventose, an. x. Boudant, Observations sur les Belemnites. Alun. du Mus. t. 16. p. 77. Faure Biguct. Considerations sur les Belemnites, ete. Lyon, 1819.

\section{Orthoceratites.}

Mr. Farey "finds them referable to twenty different places in the British series of strata; extending from (1st) the London clay above the chalk, to (20th) the limestone resting on slate." According to Spallanzani, the islands of the coasts of Dalmatic are masses of orthoceratites. M. Sage thinks, from the sections he has made, pl. 1, fig. 21, that the Orthoceratites are alveoli of different species of Belemnites, and contained within the funnel, pl. 1, fig. 29, which, however, according to M. Beudant, does not always exist. This opinion has not been generally adopted. Deluc, in particular, combated it (Journ. de Phys. vent. an. 12.), asserting that the alveoli of the Belemnites have no siphon. M. Sage considers the organization of the siphon to be evident in pl. 1, fig. 27, and in the centre of fig. 25, which is confirmed by Platt and Beudant: Montfort seems to have viewed the alreoli as the envelope of a parasite. Breynius submits fig. 30 as an orthoceratite, with the siphon passing through the axis; fig. 35 , as the convex front of the last articulation, with the siphon, of a species found most frequently in the marble of Oeland, on the coast of Sweden, four feet long, and only two inches in diameter at the base; fig. 31, or the same part of another species, whose diameter is three inches, whence he infers its length to be more than fire feet; fig. 11, p. 2 , is that of a species from Gothland, with a large siphon at the circunference, and remarkable for the projecting rays, sometimes filled with crystals of fluor, the proportion between the length and the diameter appeared to be $10: 1$. Disscrtatio Physica de Polythalmiis. Gicdani, 1732. Some are smooth, others have circular sides; both kinds are found in the greyish marble of Norway; they are of a whitish calcareous spar, with a case or envelope of a reddish brown; the chambers are separated by hemispherical yellowish lines.

\section{Hippurites.}

Some consider what we call the operculum to be the last septum, in which case the shell may be interior, unless it is hereafter discovered to be a bivalre: fig. 26 , pl. 1 , shows the gutter or canal, c. which replaces the siphon; fig. 28 is the under part of a convex operculum, with two prolongations having the appearance of a 
hinge; whether this is natural or accidental to the petrifaction cannot be decided, for no other example is known amonst the various species which have been found fig. 31 is a Hippurite, with a gutter, a, and a siphon, b; its surface is smooth and the septa are concave: fig. 33 is one of the most singular species which have yet been discovered; the operculum is entire, and pierced with two eyes; it is only six lines in depth and fifteen in diameter: fig. 18, pl. 2, found in a considerable bed on the mountain of Montforrand is sometimes a foot and a half long, the diameter not exceeding an inch; the operculum has been destroyed by long exposure; $M$. de la Peyrouse observes, that their situation in the rock clearly indicates that they have been petrified in the same position and in the same place in which they had originated. De novis quibusdam Orthoceratitum et Ostracitum speciebus Disscrtatiuncula, Erlanga, 1700. Dr. Thomson, formerly Professor of Anatomy at Oxford, saw several species in the cabinet of M. Chiarelli, at Palermo, in 1789, in the form of the femur of a cow or horse, which had been found entire at Cape Passora (the ancient Pachynus), with no bones whatever in their neighbourhood. Dr. Thomson, on visiting the spot expressly, could only meet with species in the form of a case or sheath, and equal in dimension to the horn of a bull about three years old; the interior hollow, and containing two cylindrical bodies, like two candles. The base of this cone is closed by a species of lid, similar to that of a powder horn. The internal structure resembles a heap of egg shells, broken transversely, and piled up so as to touch each other, but leaving a void space in the middle. These plates are so flexible that they allow the concave part of the horn to bend inwards when squeezed. Their disposition has some resemblance to the diaphragm of the human body. The Hippurite, therefore, is not entirely divided into concamerations, and has no tubes of communication, or siphons, as we find in the $\Lambda$ mmonites, Belemnites, and Orthoceratites. The texture of this case, as it exists in a fossil state, is scaly lengthwise and across. The transversal fracture, when it is fresh, appears to be strong, and composed of concentric layers; but after having been some time exposed to the air, this fracture appears rotten and spongy, so that in the part changed by the air, it becomes ramified like an animal substance, which gives it the appearance of a bone. This fossil case is closed by an operculum, the internal surface of which is imbricated in converging rays, like the shell of the Pecten. The thickness of the operculum led Dr. Thomson to conclude that this case was inhabited by one animal only, and that it was not the nest of several.

\section{DIVISION $V$. LITUACE压。}

\section{GENERA.}

\section{Irtues. Breynius.}

The last turn elongated.

a. Lituites, Montf.

b. Hortolus, Montf.

Turns contiguous. Pl. 1, fig. 7.

Turns separated. P'. 1, fig. 32 .

China: Foss, in the red limestonc of Ocland: Meudon; in the limestone at Namur.

\section{SchpHites, Parkinson.}

The last turn (after being enlarged and elongated) rliminished and rellected Crag Marl; Melbury Marble. 


\title{
( 21$)$
}

\section{DIVISION VI. SPIRULACEA.}

\author{
GENER $\Lambda$.
}

1. Semula. (1) Lam.

The turns of the spire not touching; divided transversally into chąmbers. Pl. 1, fig. 18.

\section{Spirolinites, Lam.}

The turns of the spire touching; the septa projecting in a small degree, so as to divide the exterior surface of the spire by crests or strix. Pl. 1, fig. 13.

\section{Ammonoceratites. (3)}

\section{Lam.}

Septa numerous, undulated at the margins. Pl. 3, terior.

Siphon occupying the Austral Seas. Gulph middle of each chamber of Florida. V. Animal, and continued to the ex- p. 54. tremity of the shell.

Siphon traversing the Grignon. (2) septa and chambers.

Siphon marginal, inRolled on itself in the same plane? fig. 14.

(1) Peron's discovery of the animal of the Spirula, so nearly akin to the Nautili that Linneus placed it amongst them, has thrown much light on all the multilocular univalves : thitherto, it was a question whether the animal inhabited the last chamber of the shell; whether it was contained entirely or partly within it; or whether the shell was enveloped more or less completely by the animal. The animal of the Spirula is perfectly analogous to the Sepia, and its shell is enchased in the posterior extremity of the body, and only visible in part. There is now very little, or no doubt, therefore, that the Rotalites, Belemnites, Hippurites, etc etc. were more or less enchased in the posterior extremity of the animal, a portion of whose body was enveloped in the last chamber, and connected, probably, by a tendinous filament inserted at the extremity of the siphon, similar to that of the Nautilus. Breynius, on the authority of Woodward (Calaloguc of English Fossils. Part I, p. 113), says, that the shells of the Spirula abound on the shores of Jamaica, Barbadoes and the Bahamas : he adds, "de figura autem animalculi domicilium hoc testaceum curiosissimum inhabitantis, altum apud omnes silentium." p. 22.

(2) Lamarck has mentioned the genus Cristelluria (Pl. 3, fig. 13), but withoui defining it, and there are none in the Museum. These shells are cretaceous, and almost microscopic. Fossil species, pyritous ur ferruginous, are found in Tuscany; and M. Defrance possesses others, which are said to have been brought up with the soundings off Teneriffe.

(3) The locality is unknown. M. Lamarck purchased it by accident: he kindiy allowed me to take it home. in order that the figure, which is the first that has been made, might be as accurate as possible. 


\section{DIVISION VII. AMMONACEE.}

\section{GENERA.}

1. Ammonites. Brug.

Septa of the chambers undulated at the mar- marginal. gins. (1).

A siphon, generally Abounding in the Secondary Mountains, from the size of a pin to that of a coach-wlieel.

a. Ammonites, Lam. All the turns visible. Pl. 1, fig. 15.

b. Orbulites, Lam. The last turn enveloping all the others. Pl. 3, fig. 11, 12.

(1) Accurding to Spallanzani, there are vast beds of Ammonites in the environs of Nevers. They have been found in Enstland, in all the formations from the 1st or alluvium, to the 8 th or first sand stonc, inclusive.

\section{DIVISION VIII. NAUTILACEÆ.}

\section{Nautilus.}

\section{GENERA.}

The last turns of the Septa numerous, simspire not only touch but ple, transverse, siphunenvelope the preceding. culated.

PI. 2, fig. 2, 3, 4.

a Nautilites. (1)

\section{S Microscopic.}

a Lenticulina, (2) Lam. The last turn, as in the existing species, pl. 2, fig. 17.

One siphen the midlle of the septa.

One siphon.. towards the anterior edge.

Several siphons... $\begin{aligned} & \text { towards the edge. } \\ & \text { scattered. } \\ & \text { ranged in a longitudinal line. } \\ & \text { ranged in a transversal line. }\end{aligned}$

A slit, instcad of a siphon .. \{ longiludinal.

B Rotalites. (3) Lam. The mouth placed more on one side than the other, or entirely on one side, pl. 2, fig. 13.

$\gamma$ Discorbites. (3) Lam. All the turns visible, pl. 1, fig. 5.

The last turn very large in comparison with the rest of the spire.

SS Large or moderate.

a Anguilites. (4) Montf. One siphon.

$\beta$ Bisiphites. Mlontf. Two siphons.

$\gamma$ Planulites. Lam. Siphon towards the edge.

$\delta$ Ellipsolites. (5). Montf. Spire elliptic, pl. 3, fig. 15.

"Analtes. Mlontf. Siphon in the middle.

(1) Foss. in the London Clay; Crag Marl; Chalk Marl; Green Sand ; Under Oỏlite; Blue Lias; Derbyshire P'eak or Mountain Lime Stone.

(2) Foss. at Senlis; Suisıon; Grignon; Meudon. Lamarck possesses Leuticuline in the recent state which were found in 125 fathoms off 'Teneriffe.

(3) Foss. Grignon.

(4) Foss Grignon. Defrance has received specimens in the recent stite from New-Holland and the Red-Sca.

(5) Foss, in the Derbyshire Peak Lime Stone. 
DIVISION IX. ARGONAUTACEI.

\author{
GENERA.
}

\section{Arconauta.}

Very thin ; the last turn so disproportionately large as to give the spire the appearance of the poop of a ship. Pl. 13, fig. 4 .
Mediterranean. Atlantic. Fossil species between Rouen and $S t$. Ouen (Pl. 3, fig. 9), and at $D$ 'Anvers. V. Animal, p. 55.

\title{
DIVISION X. CARINACER.
}

\section{GENERA.}

\section{Carivaria, Lam.}

Conical, flattened at the sides. The summit an involute and very small spire; the back with a dentated keel: very thin. Pl. 5, fig. 16.
Mouth entire, oval, Mediterranean, Atoblong, narrowed to- lantic, Indian Seas. warks the angle of the V. Animal, p. 72. keel.

\section{DIVISION XI. VAGINACEA.}

\section{GENERA.}

1. Vagineluitrs. Daudin.

Tubular, oblong; thin and pointed at one end, and an enlarged mouth at

A supcrior but no lateral aperture.

the other. Pl. 3, fig. 10 .

2. Cleodora. Peron.

Cartilo-gelatinous; like a reversed truncated $\mathrm{py}$ ramid. Pl. 5, fig. 2.

\section{Crmbula. Peron.}

Cartilo-gelatinous, very transparent, crystalline, oblong, like a truncated sabot or boat. PI. 5, fig. 3.

Aperture lateral and anterior.
In the interior of the fossil shells of the curirons of Bourdeaux.
Seas of warm climates. V. Animal, p. 56 .

\section{Hralea. Lam.}

Horny, oval-globulous ; tridentated posteriorly. Pl. $\tilde{j}$, fig. 1.

Mediterranean, Allantic, etc. V.Animal, 1. 56.

Mediterranean, near Nice.

V. Animal, p. 56 . 


\section{DIVISION XII. CLYPEACE}

GENERA.

1. Patella. (1) Lin.

Oval or almost orbicular, in dilated cones, more or less obtuse and concave beneath. Pl. 5, fig. 5, 6 . hering to the rocks and other hard substances bordering the sea.

V. Animal, p. 23.

2. Fissurella. (2) Lam.

A small hole at the Marine. V. Animal, summit. Pl. 5, fig. 10. p. 72.

3. Emarginula. (3) Lam.

4. Scutus. Montf. Par-

A notch at the posterior edge. Pl. 5, fig. 11. p. 72. MAPHORA. Blainv.

Elongated, flattened; summit apparent towards the posterior part, which is rounded; the anterior truncated. Pl. 5, fig. 4.

Marine. New Zealand. Fossil species at Grignon. Animal unknown.

\section{Septaria. Feruss. Navicella. Lam.}

Summit symmetrical, inclined towards the posterior edge : an operculum. Pl. 5. fig. 23.

6 Axcyius. Geoff.

Conical.

a. Pl. 5, fig. 7 .

A horizontal plate within.

In the rivers of wamn climates.

V. Animal, p. 72.

b. Plectrophorus, Fer. With an interior winding

V. Animal, p. 63.

Fresh-zvater.

Terrestrial. impression. Pl.6, fig. 2,3. Teneriffe. Maldives.

(1) The animal of the fresh-water Patella differs from that of the marine, although the shell has scarcely any distinguishing character. The fossil species P. cornucopic (pl.5. fig. 6.) resembles a cap, and is of considerable thickness. Foss. in Alluvia; Crag Marl; Chalk Marl; Clunch Clay; Alum Shale of Whitby; Forest Marble.-Grignon; Houdan; Pontoise.

(2) Foss. in the beds of coarse marine limestone at Grignon, and in the marl-pits of Touraine.

(3) Foss, in Limestone analogous to that at Grignon. 


\section{DIVISION XIII. MEGASTOMATA.}

\section{GENERA.}

A. In the form of a shiild or cap.

1. Capulus. Montf.

Conical, the summit curving spirally. PI. 5, fig. 13 .

Marine.

Mediterranean. Barbadoes.

V. Animal, p. 71.

\section{Hippoxyx. (1) De}

\section{France.}

Conical, summit in- Support adherent and

Marine. clined backwards. Pl. 6 , bearing (as well as the fig. 1. shell) a muscular impression in the shape of a horse-shoc.

\section{Crepidula. Lam.}

Oval or oblong, the Half closed by a hosummit obtuse, inclined rizontal plate. towards the edge. PI. 5, fig. 12.

\section{Calyptrea. (2) Lam.}

Conical, the summit vertical and pointed.

Marine.

On the rocks of the Caribluean Sea. Mediterranean.

V. Animal, p. 72.

\section{Marine.}

Atlantic, Indian Seas.

$a$ The plate (adhering to the bottom of the cone) folded, and descending vertically. Pl. 5, fig. 8.

$b$ Itfundibulum. Montf. The plate simple, almost horizontal, adhering to the sides of tbe cone, which has a spiral line on the exterior. Pl. 5, fig. 20.

5. Umbrelu. Lam.

Orbicular, slightly con- Acallous, colored disk, vex above, a small apex within. near the summit. PI. 5, fig. 15 .

Marine:

Mediterranean, Indian Seas.

(1) Several valves of different sizes having been found at Grignon, in the marlpils of Hauteville, Montmirail, etc. they were considered by some naturalists as the type of the genus Acardo. M. Defrance having remarked a similar support adhering to a recent shell (Patella mitrata, Gm.), foresaw that some other Patellax were to be separated from that Genus to form the present. His conjectures werc afterwards realised by finding one of the fossil species on its support.

(2) Foss. Grignon.

13) Foss. in the London Clay; Crag Marl; Woolwich Loam; Grcen Sand. 
B. In the form of an ear.

7. Halyotis, Lam.

Spire or spiral apex flat-

Marine. tened, excedingly small.

a. Halyotis, Lam.

Pierced by a series of holes. Pl. 5, fig. 24.

Almost all the holes ob.

b. Padolla, Montf.

A deep furrow with. in, forming a ridge literated. without. Pl. 6 , fig. 4 .

c. Stomatia, Lam.

Spire more prominent; shell deeper. Pl. 5, fig. 21 .

d. Stomatella, Lam.

Whorls carinated. Pl. 5, fig. 22 .

\section{Srganetus. Adans.}

Ditto; mouth very deep shell hidden within a spongy buckler. Pl. 5, fig. 25.

9. Testacella. Lam.

Oval, spire very small ; semi-corneous, transparent. Pl. 5, fig. 9. Pl. 6, fig. $7,8,9$.

\section{Parmacella. Cuv.}

Oblong, flat, with a slight commencement of a spire behind. Pl.6. fig. 10.

\section{Vitrina. Draparn.,}

Helico-limax. Feruss.

Very thin, transparent, flattened. PI. 5, fig. 14.
No holes.

Seas of warm climates.

V. Animal, p. 71 .

Terrestrial. South of France. Teneriffe.?

V. Animal, p. 61.

The mouth (diminish- Terrestial. Those of ed by the projection of Europe live in humid the penultimate whorl of places and are very the spire) in the form of small; those of warm a crescent, broader than climates are larger. deep.

T'errestial, Mesopotamia.

V. Animal, p. 61 .

(1) They are found on the coasts of Brillany, Asia Minor, Barbary, Western Africa, India, New Iolland, New Zealand, and California. Luid and Scheuchyer report that they have found the Halyotis in a fossil state. Bertrand, in his Dictiomairc Orictologique, says that he possesses a shell of this Genus, brought from Virginia, resembling a ferruginous stone. 


\section{( 27 ) \\ DIVISION XIY. LLLIPSOSTOMATA. \\ GENIRA. \\ A. Longitudinally rolute; the last whorl considerably larger than
the preceding.}

1. Lymieus. (1) Lame.

Spire oblong; thin ; no opcrculum. 1P.6, fig. 12.

2. PIIYSA. Drap.

Spire short or moderate; rery thin; no operculum. Pl. 6, fig. 13.

3. Melania. (2)

Outer lip advancing and narrowing the mouth; in operculum.

a. Melania, Lam.

Peristoma complete, effusive (3) at the base

Columella* with a longitudinal fold entering obliquely into the moutl.

Columella simple.

In stagnant waters and marshes.

V. Animal, p. 63.

In springs. V. Animal, p. 63.

\section{Marine and Fresh} Water.

V. Animal, p. 67.

Turreted.

Fluvialic, Isle of France. Madagascar. East Indies.

Marinc.

Sub-globular. thinc.

Turreted.

Fluviatic.

Turreted; spire curved. Marinc. plete, not effusive; very thick: white. Pl. 6, fig. 15.

c. Melanopsis, Lam.

Peristoma incom. plete, inner lip very broad, reflected, effusive; black. Pl. 6, fig. 18.

d. Melanella, Dufresne.

Semi-transparent, mouth invaded by the last whorl; white. Pl. 6 , fig. 17 .

(1) Foss. in the Cowes Roch of Limestone; Grignon; 1st and 2nd Fresh Watcr Formations of the environs of Paris. * See the section Pl. 12, fig. 16.

(2) I have ventured to separate the marine Melanix, under the name of Mclantho, the Mclanclla (in the cabinet of M. Dufresne), and the Melanamona; adding the name of Mclanatria to Lamarck's Pyrene, in order to indicate its connexion with the others. Foss. in the London Clay; Purbech Limestone; Coral Rag; Blue Lias; at Grisnon, Courtasnon, Houdan, Pames and Ponchartrain. The fossil species of Melania found at Grignon differ remarkably from the fresh water species. In the $M$. costcllata, pl.13, fig. 11, the peristoma is continuous, but the mouth is not circular, and it is entirely detached from the columella towards the upper part of the lip. In the .1 . cochlearclla, pl. 13, fig. 13, the lip is prolonged like a spoon; in the 1. marginata, pl. 13, fig. 10, the peristoma is margined or thickened. The fluviatic Mcluniabrought by Olivier from the East are very distinct in appearance from all other species: see Pl. 8, fig. 14, 17. This Genus is, probably, entirely foreign to Europe.

(3) Versante is the French $\mathrm{crm}$, which they explain by saying if the shell were laid on its back and filled with water, it would run out at this part of the mouth: this has been concluded to be the meaning of Linneus's term Effusus, but it appears improbable that lar: should take a perfect instead of a present participle, when we consider his Latinity. 
c. Miclanamona.

Efrusive, with one
very deep sinus; black.

Turreted.

Fluvialic.

Pl.6, fig. 19.

f. Melanatria. Pyrene.

Lam.

With 3 undulating $\ldots \ldots \ldots \ldots \ldots$ sinuses : black. $\mathrm{Pl}$. 6 ,

fig. 20.

4. Phasianella. (1) Lam.

Oblong : operculum, Columella simple, flatcalcareous. PI. 6, fig. 21, tened at the base.

Marine. Indian Seas. Shores of New Holland. V. Animal, p. 67.

\section{Aunicula. (2)}

Oval or oblong, outer Columella, witl large lip thickened. Pl. 6, fig. oblique channellings or 22.

folds; no umbilicus.

Mostly Fresh Water, but some Marine.

V. Animal, p. 63 .

\section{Scarleaus. Montf.}

Oblong-oval, spire a- Inner liptootled, with cute; outer lip thickened, a hollow below the middentated. Pl.6, fig. 23. dle.

On herbs in the Noluccas. The marshes, wvoods, and mountains of Asia.

Animal unknown.

\section{Carychum. Muller.}

Oval or oblong, spire obtuse; outer lip thickened, margined; penultimate whorl much larger than the preceding, but considerably less than the last; no operculum. Pl. 6 , fig. 24 .

Immer lip plicate with a hollow below the middle, the upper part wanting. The Ifoods of Europe, under moss. Sit. Vincent's.

\section{Covovulus. Lam. \\ Melampus. Montf.}

An inverted cone; lip Columella with profinely striated; no opercu- jecting folds. lum. Pl. 6, fig. 25.

Rivers of the West Indies.

$$
\text { T. Animal, p. } 63 .
$$

\section{Achatina. (3) Lam.}

\section{Agathina.}

Oval or oblong.
Columella truncated at the end.
Trees and sands of warm climates.

V. Animal, p. 62.

(1) Foss. in the Cowes Rock of Limestonc.

(2) Foss. in the Loudon Clay; Gren Sand; at Grignon.

(3) A smooth, thin, globulous shell is funnd in the marine deposits of Plaisantin, approaching very nearly to the Ichatina, but wilhout the columella beiner truncated at the base, pI. 8, fig. 22. Brocchi calls it Bulla IIclicoüdes. 
a. Liguus, Mlontf.

A callosity within the last whorl, P1. 6, fig. 26.

b. Polyphemus, Montf.

The end of the columella curving inwards. Pl. 12, fig. 11 .

10. Bulimus. (1)

Oral, or oval oblong.
Columella smooth.
On rocks and trees in cool shady places. Large species in warm climates.

V. Animal, p. 62 .

a Bulimus, Lam. Outer lip thick, blunt, pl. 6, fig. 27.

6 Bulimopsis, Lam. Outer lip thin, sharp, pl.4, fig. 15.

c Bulimulus, Lcach. Outer lip thin, sharp; inner lip inflected, pl.6, fig. 28.

11. Amphibulma. Lam.

Succixea. Drap.

Elongated or oval ; spire, V. Animal, p. 62. short, of 2-4 whorls, the last forming almost the whole of the shell. Pl. 6 , fig. 5, 6. Pl. 7, fig. 5,6 .

12. Tornatella. Lam. Actæon. Montf.

Spire projecting but lit- Columella with one or tle ; mouth elongated, en- two large folds. larged below. Pl. 6, fig. 29.

Marine.

Coasts of Africa.

V. Animal, p. 63.

B. Longitudinally volute; the last whorlwery little larger, or less, than the preceding.

13. Guausilia. Drap.

Slim, long, pointed; With or without teeth the last whorl contracted, or projecting plates. compressed; mouth edged with a callous pad: Pl. 6 , fig. 36 .

(1) Fossil species have been found in the $2 d$ Fresh W Water Formations of the environs of Paris. The marine species at Grignon have not the same generic character as the Bulimi, according to Brongniart, and ought to be referred to the Phasianellæ. Lamarck has observed that only terrestrial shells have the lip reflected. The Bulimus dombeyanus, B. octronus, and B. tercbraster, pl.13, fig. 15, and many other species which inhabit $\Lambda$ sia, $\Lambda$ frica, or America, are turreted with numerous whorls; others are of a conical form, as the Bulimus trochoides of Bruguiere. See the singular species, and its monstrosity, Pl, 6, fig. 35. 31. 


\section{Odostoms. Fleming.} whorl.

Spire produced; mouth contracted, subangular, distinct from the body

With teeth or plates.

a. Spire dextral. Pl. 8, fig. 28.

b. .. sinistral, $\mathrm{Pl}$. 8, fig. 23.

15. Pupa. (1) Lam.

Summit obtuse; mouth narrowed by a callous pad, and diminished on the side

With or without tecth or plates.
The greater number terrestrial; understones, on rocks, and in mosses.

Ánimal unknown. of the spire by the preceding whorl. Pl. 6, fig. 37, 34 .
Cylindrical.
a Without a tooth, pl. 8, fig. 29. $\left\{\begin{array}{l}b \text { A tooth in the part of the mouth invaded by the penulti- } \\ \text { timate whorl, pl. 8, fig. } 32 \text {. }\end{array}\right.$
c Teeth within the outer lip, pl. 6, fig. 37 . pl. 8, fig. 24.

C. Horizontally volute; mouth transyersally elliptical.

16. Playonbrs. (2) Brug.

Rolled almost in the same plan; the whorls increasing gradually; no operculum. Pl. 6, fig. 32.

\section{Heurx. (3)}

Globulous or subconical, spire depressed; mouth somewhat diminished by the projection of the penultimate whorl. PI. 7.
Slagnant waters. V. Animal, p. 63.

(1) The shells of the marine and terrestrial Pupe are similar, but an experienced Conchologist may always distinguish them : the animal of the former is not known. Lamarck doubts the Pupa mumia to be marine. Foss. in the $2 d$ Fresh W Fater Formation.

(2) Fossil species have been found in the Limestone of Fontaincblean (2d Fresh IIater Formation); in the Silcx near Paliscau (2nd Fresh Water Formation); in the Marne Blanche covering the Gypsum at Pantin and Chatmont (1 st Fresh IV ater Formation); in the Coures Rock of Limestone; London Clay; Grecn Sand; Under Oolite; Derbyshire Pcal Limestone. Neither of the three Planorbes cited at Grignon can be exactly referred to this Genus; the Carinata resembles the Detplinata.

(3) The distinction of fresh water formations, so precisely established by Grolorists, has made it indispensably necessary to study this Genus attentively. An arrangement with a view of easily distinguishing the species is difficult, from the great accumulation, for whilst the shells present the greatest varieties of form, the animals offer no differences of any importance. As M. de Ferussac appears to have studied the excessively numerous species of $t$ l: is Genus more completely than any other author, accompanying the publication of his system, which comprchends all the known specics, with accurate and beautiful engravings, I shall adjoin his 
a IIelis, Lam. Globulous, pl. 7, fig. 9.

b Caracolla, Lam. Carinated, conical, pl. 7, fig. 22.

c Anostoma, Lam. Mouth dorsal, toothed, pl. 7, fig. 20.

\section{Helicina. (1) Lam.}

Subglobulous or conical ; spire a little depressed ; inner lip enlarged at the base in a callous pad entirely covering the umbilicus ; a small blunt angle at the base of the right lip. Pl. 12 , fig 6.

19. Helicarion. Ferruss.

Very thin, transparent.

Colımella spiral, solid, formed by the inner lip and confounded with the whorl of the mouth.

20. Ampullaria. (2) Lam.

Round and ventricose, spire short; umbilicate; operculum horny.

a.

Mouth narrower, more elliptical, thinner. Pl. 9, fig. 1 .

\section{Ampullina.}

Considerably thicker. Pl. 9, fig. 2.

\section{Columella umbilical.}

Columella callous.

Terrestrial.

V. Animal, p. 66 .
Marine.

Australasia.

V. Animal, p. 62 .
Inner lip sharp.

Marine.

V. Animal, p.

method of distribution, impressing that it is purely artificial. The Helices being terrestrial shells, it appears extraordinary that we should meet with them in the fossil state in marine deposits; but when that happens they have been brought there by floods or rivers, or by some irruption of the sea, attesting that previously to these deposits there had been dry land in the same places, whereon the animals lived which formed the shells. The Marl Pil of Touraine is the only place on record where they thus occur, and there they are frequeutly filled with the remains of Polypi and marine shells. Fossil IIelices are generally found in Fresh $\mathbf{H}$ ater Formations, and often accompanied by Lymnxi and Planorbes. We meet with them in breccia. and sometimes in the districts which have been overthrown by volcanocs. In England they have been found in the Cowes Rock of Limestone, in the Grecn Sand, and in the Derbyshire Peak Limestone.

(1) Foss. Blue Lias Limestone.

(2) Their opercula, being horny, are never found, although these shells are very common in beds of coarse, calcareous, shelly matter; whilst the opercula of the Natica, to which some authors would refer them, are very frequently met with, from their being calcarcous. Fossil Ampullarix are also found in the cxtinct volcanocs of the valley of Ronca, where they have been so disposed by the eruptions as to preserve their colours. MI. Faujas found a species of Ampullaria, with a very thick shell, at St. Paulet, near Pont St. Esprit, in bituminous marl, above a mine of fossil cual; the upper edge of each whorl bears an ascending keel, and it differs from all that are known, by an oval mouth, pl, 12, fig 12,13,14. 


\section{DIVISION XV. HEMICYCLOSTOMATA.}

\section{GENERA.}

NentTa, Lin.

Semi-globulous; mouth Columella in a straight semi-circular or semi-cl- line.

liptical, closed entirely by an operculum ; spire almost effaced.

a. Natica, (1) Lam.

Operculum horny. Columella umbilicate. Pl. 9, fig. 24.

Marinc.

V. Animal, p. 67.

b. Nerita, (2) Lam.

Operculum stony, Columella umbilicate, shell thick. Pl. 9, fig. dentated. 20.

V. Animal, p. 67.

e. Neritina, Lam.

Operculum horny, Columella rarely denshell thin. Pl. 9, fig. tated. (3)

Fluviatic. 21.

V. Animal, p. 67 .

(1) In the fossil state, in the London Clay and Crag Marl; at Grignon.

(2) In the fossil state, at Retheuil, Courtagnon, Houdan, Grignon.

(3) Those with the columella dentated form the genus Clithon of Montfort, whose Clithon corona, pl. 9, fig. 23, differs from the Clithon coronata of Leach. 


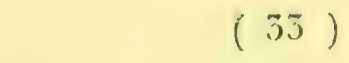

\title{
DIVISION XVI。CRICOSTOMATA.
}

\author{
GENERA.
}

1. Turbo. (1) Lam.
Round or oval; thick.
Mouth completed by the penultimate whorf.
Marine.
V. Animal, p. 65.

a. Meleager, Montf. Umbilicate. Pl. 9, fig. 3.

b. Turbo, Montf. Not umbilicate. Pl. 12, fig. 15.

2. Turritella. (2) Lam.

Spire elongated like an Mouth completed by obelisk; thin: operculum the penultimate whorl. horny or cartilaginous. Pl. 9, fig. 12. Pl. 12, fig. 17.

\section{Vermicularia. Adan-} son.

Whorls not touching, Ditto. irregularly curved. PI. 9, fig. 17.

Marine.

V. Animal, p. 65.

\section{Delpinula. (3) Lam.}

Thick; rolled almost in Mouth cntirely formed the same plane. Pl. 9. fig. by the last whorl. 16.

\section{Scalaria (4) I am.}

Turreted, with pro- Ditto; but margined. jecting sharp longitudinal ribs. Pl. 9 , fig. 6 .

Marine.

V. Animal, p. 65 .

\section{Acrona. (5) Leach. WENDLETRAP.}

Ditto, but whorls dis- Mouth entire and martinct and distant; no co- gined. lumella. Pl. 9, fig. 5,

Marine.

V. Animal, p. 65 .

(1) Foss. in the Crag Marl; at Presles; Grignon. No fossil species of this genus has been discovered in the Fresh W Water Formations; the little shelle of the ponds of Havre and Magentone bave been erroneously referred to it.

(2) Foss, in the London Clay'; Crag Marl; at Grignon, Chaumont.

(3) Foss. Grignon, Courtagnon.

(4) Foss. in the London Clay; Crag Marl; at Grignon, Presles.

(5) "The museum of Mr. Bullock contains the largest known specimen of the Aciona Scalaris, which was purchased at a sale for twenty-seven pounds; but it is now estimated at worth more than double that sum.,"Lcach's Zoological Miscellany, vol. 2.1815. 
7. Crclostoma. (1) Lam.

Oral-spiral, mouth round or nearly round, closed entirely by a round,

Mouth bordered by a callous pad. tic.

Tervestrial and aqua-

T. Animal, p. 66.

thin, calcareous operculum : peristoma complete. PI. 9, fig. 13, 14.

\section{Valvata. Muller.}

Rolled almost in the same plane. P1. 9, fig. 22.

Fresh waters. ,

Y. Animal, p. 66 .

\section{Paludina, (2) Lam.} Vivipara. Montfort.

Oval-spiral ; operculum with an angle like that of the mouth. Pl.9, part fig. 15.

\section{Moyodonta. Lam.}

Oval, or conical ; operculum round, horny. Pl. 9, fig. 25.

A blunt and slightly projecting tooth at the base of the columella. Base flat or concave.
Marine.

I. Animal, p. 66.

(1) Young Cyclostome may sometimes be confounded with the shell of the genus T'urbo; for the upper part of the peristoma is not completed, that is to say, the lips do not join, before the adult state; in the Turbo they always remain separated. The Missenau chain of hills near. Mayence is composed of fossil Cyclostoma, not of Bulimi, and of two species which, according to M. de Ferussar, are again found in Qucrey, Agcnois, and in Silcsire. M. Brongniart expects that the Cyclostome will hereatter be dirided into two genera; the one aquatic, the other lirrestrial. The C. mumia, Lam.pl. 4, fig. 1, belongs to the latter; it has only been found as yet in the 1st of Lower Fresh $W$ ater Formation in the environs of Paris; M. Brongniart conceives that on further investigation it may be found to characterise it: the enlargement or projection of the upper part of the peristoma is uot unfrequent in the living species. All those indicated at Grignon dilfer from true Cyclostoma, The Cyclostoma carinata of the canals of Egypt, Pl. 13, fig. 9; C. bulimoides of the environs of Alexandria, Pl. 8, fig. 13; C. unicolor, Pl. 8, fig. 15; and the Helix cre. ncluta, Pl. 12, fig. 10; brought by Olivier, differ in form from all the other freshwater shells yet hown, and, as M. Brongniart justly observes, if found in the fissil tate, would certainly have been considered as marine.

(2) Foss, in Cravel and Alluvial Clay; London Clay; Crag Mart. 


\section{$(35)$ \\ DIVISION XVII. GONYOSTOMATA}

GENERA.

1. Trocius. (1) Lam.

Conical; mouth more or less quadrangular, in an oblique plane to the axis of the shell; operculum thin, horny, orbicular.
Base flat or concaye.

Marine, or inhabiling the brackish ponts communicating with the sea.

Y Animal, p. 66 .

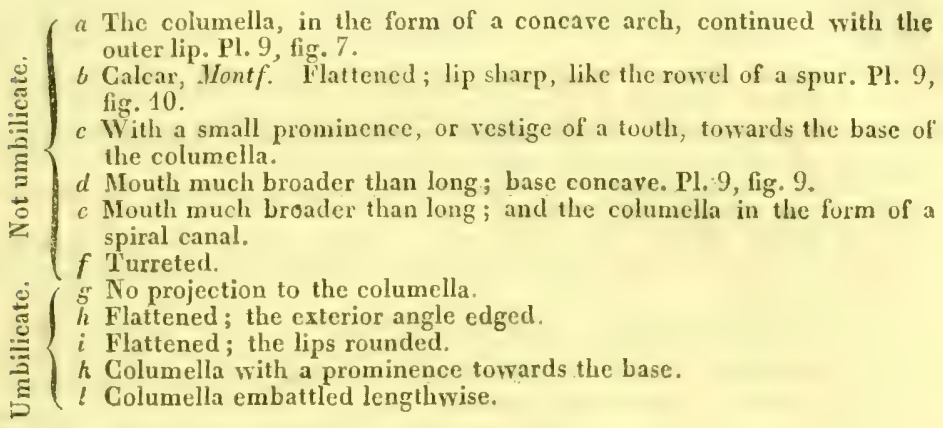

2. Cirrites. Sotverby,

Conical; whorls united. Pl. 9, fig. 4 .

3. Solarium. (2) Lam.

Spire like a dilated cone. Pl. 9, fig. 11.

\section{Euomphalites. Solv- erby.}

Rolled almost in the Concave or largely umsame plane, depressed bilicate underneath. above. Pl. 9, fig. 18, 19.

\section{Ianthixa. Lam.}

Subglobulous, horizontally volute; no opercu- beyond the mouth. lum. Pl. 9, fig. 26.
No columella: umbilicus funnel-shaped.

A very large umbilicus, hollowing out the base.
Columella prolonged
In the Chalk Marle. under Oolite, and Der. byshire - Peak Limestone.

\section{Marine.}

V. Animal, p. 66 .

In the LimestoneShale; in the 1st or Upper Grey and in the Peak Limeslone of Derby shive.

Marine.

Mediterranean. Aus. tralasia.

A floating shell. V. Animal, p. 67.

(1) Foss in the London Clay; Cras Marl; Onder Oolite; Blue Lias ; at Grimon; near Pont Churtrain; Longjumeau. The Trochus agglutinaus, Pl. 9, fig. 8, is remarkable for its habit of agglutinating to, and even of incorporating with, its shell, during the growth, small pebbles, fragments of other shells, sand, etc. etc. It often covers the umbilicus with a testaceous plate. A fossil variety of this curious shell, which inbabits the seas of South America, is found at Grignon.

(2) Foss, in the London Clay; Purbech Limcstonc; at Grignon. 


\section{DIVISION XVIII. SYPHONOSTOMATA.}

GENERA.

A. With varices. (1)

\section{Murex. (2) Lam.}

Oval or oblong; turbi- Varices in two opposite nated, canal projecting rows.

Marine.

V. Animal, p. 70 . and straight; operculum horny.

a Murex, Monlf. Canal long and slim; varices spinous. Pl. 10, fig. 3.

$b$ Brontes, Montf. Canal long and slim; varices knotty.

c Typhis, Mont. Canal moderate; varices spinous, with projecting tubes between, penetrating the shell. Pl.12, fig. 7.

d Chicoracex, Montf. Canal moderate or long, with folded leaves notched or divided. Pl. 10, fig. 5 .

e Aquila, Montf. Canal moderate or short; varices knotty; umbilicate.

$f$ Lotorium, Montf. Canal moderate or short; varices knotty; not umbilicate.

g Tritonium, Montf. Canal moderate or short; varices simple; spire elerated; mouth generally wrinkled transversely on both lips. Pl. 10, fig. 4.

h Trophones, Montf. Canal moderate or short; varices numerous, compressed, almost membranous.

i

Canal moderate or short; varices few, very much compressed, projecting considerably.

\section{Ranella. Iam.}

Turbinated; canal short ; surface armed with tubercles; lips of the mouth wrinkled. Pl. 10, fig. 6 .

a. Apollo, Montf. Umbilicate.

B. Without varices.

\section{Fusus. (3) Lam.}

Fusiform, peristoma en- Columella simple. tire; spire elevated.

Tarices bordering both sides.
Marine.

V. Animal, p. 70.

\section{a. Fusus, Montf. Umbilicate.}

b. Lathires, Montf. Not umbilicate. Pl. 10, fig. 7.

(1) Varices are projecting callous pads with which the animal edges the mouth or aperture of its shell, each time that it suspends the growth. V. Pl. 10, fig. 2, $a, b . c . d . c$.

(2) Foss. in the London Clay; Crag Marl; Woolwich Loam; Grecn Sand; at Grignon, Courtagnon. The Murcx tripleris, living in the Indian Seas, near Bataria, is very common at Grignon.

(3) Foss. in the London Clay. In France they are found in the nowest Shelly Limestonc, and are much more abundant in that than in any other formation. Although the fossil species are numerous, we meet with scarcely any which are perfectly analogous to those now found in the recent state. These remarks also apply to the Fasciolaria. 
1. Fasciolaria. Lam.

Subfusiform. Pl. 10, Columella withoblique Marine. fig. 14.

folds at the base.

V. Animal, p. 20 .

a. Fulgur, Montf. Whorls of spire flattened at top; striated within the mouth.

5. Jurbinella. Lam.

Turbinated or subfusi- Columella with large form. Pl. 10, fig. 15.

transverse folds.

Marine.

Y. Animal, p. 70.

6. Prrula. (1) Lam.

Subpyriform : spire flat- Columella simple. tened or rounded.

Marine.

Generally in warm climates.

V. Animal, p. 70.

a. Umbilicate. Pl. 10, fig. 8.

b. Not umbilicate.

7. Pleurotoma. (2) Lam.

Fusiform; a notch in the right lip towards the

Ditto.

Marine.

spire; canallong : opercu-

V. Animal, p. 70.

lum horny. Pl. 10, fig. 13.

8. Cuavatula. (3) Lam.

Subturreted; a notch in the right lip towards the spire; left lip excavatColumella toothed. Marine.

Coasts of Africa. ed; spire pointed. PI. 13. Auimal unknown. fig. 8 .

(1) Foss. at Grignon; Courtagnon; Houden; Parnes.

(2) Foss. in the London Clay; Creen Sand; at Grimnon; Betz, near Crepy ; Parms.

(3) There is no (laeatule in the Museum; I was therefore compelled to copy the obscure figure of Seba. 
DIVISION XIX. ENTOMOSTOMATA.

\section{GENERA.}

A. Turreted.

1. Eeurna. Lam.

Shell smooth. P1. 10. fig. 9 .

Columella deeply and broadly umbilicate.

2. Ancillaria. (1) Lum. A scilla.

Oblong, spire short. Pl. 10, fig. 10 .

\section{Mrtra. (2) Lam.}

Turreted or sub-fusiform; spire pointed, folds, the largest nearest. mouth oblong. $\mathrm{Pl}$. 10, the spire. fig. 11 .

\section{Pyramidella. Lam.}

Mouth broad, crescent shaped. Pl. 10, fig. 12.

\section{Terema. (3) Brug.}

Spire at least double the greater diameter of the mouth: no operculum. very short. Pl. 10, fig 20.

\section{Cerrithium. (4) Brug.}

Mouth oval, curved to the left at the notch : oper-
culum round and horny.

A gutter in the upper part of the right lip.
Marine.

V. Animal, p. 69.

Marine.

A callous pad on the
base of the columella.

Columella with the base twisted obliquely in sharp, spiral folds.
Marine.

Warm climates.

V. Animal, p. 69.

Marine.

V. Animal, p. 63.

a. With varices, but no fold on the columella.

b. With folds on the columella. PI. 13, fig. 2.

c. No folds on the columella; no varices. Pl. 10, fig. 19.

(1) Foss, in the London Clay; at Grignon; Couragnon; Environs of Paris.

(2) Foss. at Grignon; Parnes near Magizy.

(3) Foss. at Grignon; Parnes.

(4) This genus of univalves presents more species in the fossil state than any other. There are already upwards of a hundred in the cabinet of M. De Franze: they are almost all found in the newest formations. M. de Gerville however, reports that he has found four species in the bed of Ammonites and biclomites, in the environs of Bayeux.-. Jinrmal de Physigue, October, 1813. They have heen found in England, in the London Clay aid in the Chalk Marl. The Cerithium Gigras, pl. 13, fig. 2, is sometimes from fifteru le sideen inches Insg, and font in diametes at the last whorl. 
7. Potamors. (1) Brongn.

Notch less apparent, right lip dilated. PI. 10,

No gutter.

Salt-ivater marshes, or the brackish waters of the mouths of rivers. fig. 18.

8. Rostellaria. (2) Lam.

Fusiform ; a second canal, ascending along the spire, formed by the outer lip and by the continuation of the columella. PI. 10, fig. 16.

\section{Oral, sub-conical, or sub-globulous.}

\section{Buccrnum. (3) Lam.}

Oval or elongated; Columella convex, namouth notched below; ked.

Marine.

V. Animal, P. 70 . lips simple : operculum cartilaginous. Pl. 10, fig. 21 .

\section{Doliux. Lam.}

Ventricose; sub-globulous; outer lip undulated, notched below. PI. 10 , fig. 22 .

\section{Harpa. (4) Lam.}

Oval or gibbous; with longitudinal or oblique sharp ribs, the last forming a callous pad at the lip; mouth oblong, simple, notched below. Pl. 11, fig. 1 .

Columella smooth.

Columella twisted or sharp at the base.
Mariue.

V. Animal, p. 69.
Marine.
T. Animal, p. 69.

(1) This Genus is funded on the habits of the animal, rather than on the im . portance of the character of the shell. Fossil species are found in formations presenting only terrestrial and fresh-water shells. P. Lamarchii, pl $i$. fig. 6 , is found in the oparue silex which covers the sand at Lonsjumean; in the forests of Montmorency; above St. Cloud; mixed with Lymnxi, Planorbes, and stalhs of reeds in the Limestone, east of Aurillae. in Cantal; in the compact limestone beds (with the Helix Cocruii, pl. 4, fig. 20), at Nonctte, near Issois, in P'uy de Dome. It resembles the C'rithium radula, figared by Lister as a fresh-water shell; and, in a lesser degree, the Bulimus auritus of Bruguiere, from the interior of Africa.

(2) Foss. in the London Clay; at Courtagnon; St. Germain en Laye; Parncs.

(3) Foss. at Grignon.

(1) Although the Harpa ase by no means vare in the seas of warm climales, unly two species have at get been found in the fuesil state. and those in the course shelly Limestone at Grignon and Hauteville. 
12. Nassa. Lam.

Oval; mouth terminated

below by a deep notch. a plate.

Pl. 10, fig. 23.

13. Purpura. (1) Lam.

Oval. Pl. 11, fig. 2.

a. Purpura .

b. Monoceros, Montf.

- Ricinella, Lam.

14. Coxcholepas. Lam.

Patelliform ; outer lip dentated; spire very small : operculum oval, horny. Pl. 10, fig. 17.

\section{Cassidiria. Lamz}

Monso. Montfort.

Conical; mouth effusive; notch terminating in a small canal reflected to the left at the base. PI. 11, fig. 6.

\section{Caxcellaria, (3) Lam.}

Oval, last whorl ventricose, right lip furrowed within the mouth almost entire at the base. Colum
tened.

Columella naked, flat-

\section{tern.}

A spine projecting from the base of the outer lip. P1. 11, fig. 3 .

Lip of the columella toothed. Pl. 11, fig. 4.
V. Animal, p. 69.

\section{Marine.}

V. Animal, p. 69.
Marine.

P1. 11 , fig. 6 .

(1) Foss, at Courtagnon.

(2) Lamarck placed the Concholepas with the Priclla, but most zoologists seem now to agree with Bruguiere in approaching it to the bucciuum, since, according to Dombey's report, the animal is furnished with a tendinous operculum, which only partly closes the shell. The muscular impression, like a large horse-shoe open in front, has some resemblance to that of the Calyptraa.
Marine. pressed folds and a plate formed by the inner lip.
Marine.

Const of Peru.

Animal unknown.
Columella covered by a simple plate formed by the left lip.
Marine.

V. Animal, p. 70.

(3) Foss. at Grignon; Picdment; Environs of Florence. 


\section{(41) \\ DIVISION XX. ANGYOSTOMATA.}

GENERA.

A. With folds, plaits, or wrinkles, on the columella.

1. Cassis. (1) Brug.

Oral; mouth oblong or narrow ; the notch termi- a plate formed by the left nating in a short canal re- lip, wrinkled transverflected towards the left at sally. the base; right lip wrinkled transversally.

Marine.

Gencrally in warm climates, at some distance from the shore, in sandy bottoms.

V. Animal, p. 70.

a. The callous pad of the lip dentated exteriorly towards the notch. Pl. 11, fig. 11 .

6. The callous pad of the lip not dentated exteriorly towards the notch.

2. Crpnæa. (2) Lam.

Oval, gibbous in the Mouth long, narrow, middle, and narrowed at wrinkled transversally V. Animal, p. 68 . both ends; lip rolled in- on both sides. wards : no cpidermis. Pl. 11, fig. 7, 9. $a, b, c$.

\section{OLwa. (3) Lam.}

Sub-cylindrical; notch- Columella striated obcd at the base; mouth nar- liquely.

row; channels between the whorls of the spire. PI. 11, fig. 13.

\section{Coxoelix. Swainson.}

Coniform; spire very short; mouth linear, narrow. Pl. 12, fig. 1.

Columella plaited.

\section{Voluta. (4) Lam.}

Oval; spire varying in projection. summit obtuse the low est the largest. or nippled. Pl. 12, fig. 2, $3,4,5$.

a Gymbium, Montf. The last whorl ventricose

Columella with folds,

6 Voluta, Montf. The last whorl conical, narrowing at the ends.

a (1) The fossil species (and annongst them the Cassis Harpaformis, pl. 11, fig. 12) are found only in the now st formations, and it is remarhable that they are very small, compared with the living ones, which are sometimes of a considerable size. Thes have been found in England in the London Clay and in the C $\mathrm{rag}$ M Marl.

(2) In the infant state, the (yprea resembles a small thin Ancillaria, curred and truneated at the base, pl. 11, fig. 9, $a$; in the middle age, it is thin, with a project. ing spire, pl. 11, fig. 9, $b$; when adult, it is thicher, and the spire is covered, pl. 11 , lig 9, c. Foss. in the London Clay; at Grignon.

(3) Foss. at Grignon; A tumont, near Montmorcncy.

1) Foss. in the Lendon Clus; in the Cras Hart; at Grignen; Crurtagnon; Chaumont; Berturais. 
6. Marginelia. (1) Lam.

Oblong-oval; a projecting callous pad on the outer lip ; mouth scarcely notched at the base: no operculum.
Columella with folds.

\section{Marine.}

Seas of warm climates, principally in the neighbourhood of the Senegal:

V. Animal, p. 69.

\section{a Spire conical. Pl 11, fig. 20. \\ b. Spire obscure. Pl.11, fig 19.}

$c$ Colombella, Lam. The callous pad of the right lip swelled in the middle; folds of the columella numerous. 11.11, fig. 17.

7. Volvaria. (2) Lam.

Cylindrical, no appa- Columella with one or rent spire; mouth narrow, several folds at the base. as long as the shell. Pl. 11 , fig. 18.

B. Columella simple.

S. Struthiolaria.

Inm.

Turreted: 3 umdulating Columella covered with sinuses. Pl. 12, fig. 9. a plate formed by the left lip.

Marine.

Marine.

Animal unknown.

\section{Srnombus. (4) Lam.}

Ventricose, with a short canal; notched or trun- below.

cated at the base; right lip dilated in a wing (in the adult), with a sinus towards the base : operculum horny, long, narrow. Pl. 11, fig. 15.

\section{Terebellum. (5) Lam.}

Oblong or sub-cylindrical ; mouth narrow above, simple, cnlar ed towards the base, notchcd. Pl. 11, fig. 14.

\author{
Colımella truncated Marine. \\ Generally in warm \\ climates. \\ V. Animal, P. 70.
}

(1) Foss. at Grignon.

(2) Foss. at Grignon.

(3) The Muscum gave 100 francs for the type of this new genus, which is nun figured for the first time.

(4) Foss, in the London Clay; at Grignon.

(5) Foss, at Grisnon; Environs of Paris. The Terelellum perditum (the analogous living species is not known' is found in great numbers, and of all ages, at Grignon. 
11. Prenocend. Lam.

Ventricose, with an elongated canal; right lip dilated in a wing (in the adult) divided into long, narrow digitations. Pl. 11, fig. 16.

12. Cosuss. (4) Lam.

Like inverted cones, or cylindrical ; mouth longitudinal, narrow, simple, effusive at the base : opeiculum small, horny.
Murine.

V. Animal, p. 70.
Marine.

Generally within the tropics, at ten or twelve fathoms decp, near sandy coasts.

V. Animal, p. 68 .

a Conical spire, crowned with tubercles. Pl. 11, fig. 21.

$b$ Conical spire, not crowned with tubercles. Pl. 11, fig. 22.

c Sub-cylindrical spire, not crowned with tubercles.

13. Ovula. Brug.

Gibbous, elongated in Both lips rolled in- V. Animal,p. 68. a point at eachend; mouth wards.

longitudinal. PI. 11, fig. 8,10 .

\section{4. АKERA. Muller.}

Oval-oblong or ovalconcave; more or less Right lip sharp.

Marine.

In the muddy boltoms of the seas of all climates.

V. Animal, p. 61 . jecting spire; mouth as long or almost as long as the shell, without notch or canal.

a Bullxa, Lan. Contained within the mantle, too small to hold the animal. Pl. 5, fig 18.

b Bulla 5), Lam. Covered with a thin epidermis, large enough to contain the animal, and turned more than the BULLEA. P1.5, fig. 17.

C. Almost flat.

15. ApIYYSA. Lin. LAPLISIM. Lam.

A litule convex within, obliquely conical; base

Horny.

Marine.

V. Animal, p. 60. thin, summit thickened and obscurely spiral. Pl. 13, fig, 5 .

(4) Foss. at Courtagnon; Grignon. The Conus depcrlitus, Lam. found in the ralcarcous shelly matter in the environs of Paris, is, according 10 Bruguiere, the analngous fossil of the Cone treilliser, which lives in the Pacifie Oecan, in the neigh. bourhood of Otaheite.

(5) Foss at Grignon. 
16. Dolabelua Lam. Pl.

13, fig. 6.

Ditto, but base more enlarged in proportion ; summit more prolonged and curved.

Calcareous.

Marine.

Mediterranean, Indian Seas.

V. Animal, p. 60 .

Marine.

V. Animal, p. 60 .

18. Planospinites. (1) Faujas.

Sub-orbicular; a spiral cord-like ridge on the inferior surface. Pl. 1, fig. 20.
Maestricht.

(1) This is one of the rarest and most singular shells found at Maestricht, only three having as yet been met with. It seems impossible to determine whether it is an univalve or a bivalve; for although it resembles the valve of an oyster in form and thickness, it wants the little hollow found at the summit of that shell and serving to lodge the ligament which characterises the genus; neither has it any apparent muscular impression. If it be a bivalve, it is nearest to the genus Acardo of Lamark, but its spiral cord or ridge, wilh the absence of the hollow and muscular impression, lead us to conclude that it is an univalve. 


\section{GENUS HELIX. (1) FERUSSAC.}

\section{SUB-GENERA.}

A. Horizontally volute.

1. IIelicogena. Fer.

Globulous or elliptical ; Umbilicus masked. peristoma simple.

a Collumellatx. Columella solid and twisted. Pl, 7, fig. 7, 8 .

$b$ Acarx. Umbilicus entirely covered by an expansion of the columella. Pl. 7, fig. 11, 14 .

c Perforatx. Umbilicus appearing in part, like a cleft, behind the expansion of the columella. Pl. 7, fig. 9, 10 .

d Imperforatx. Depressed, umbilicus closed. Pl. 7, fig. 15, 16, 18.

2. Helicodonta. Fer.

More or less globulous Mouth generally toothand depressed; peristoma ed in the perfect state. reflected or thickened.

a Personatx. Peristoma sinuous and thick; or reflected with teeth, plates, or folds.Pl. 7 , fig. 17.

$b$ Lamellatx. Mouth with one or more elongated internal plates. PI. 7, fig. 19, $a, b, c, d, c$.

c Maxillatx. Peristoma with large teeth; a gutter at the base of the columella. Pl. 7, fig. 21 .

d Anostomx. Tomogeres, Montf. Nouth reversed or dorsal, with elevated folds or teeth. P1. 7 , fig. 20 .

c Impressx. Inner lip with longitudinal elevated folds. Pl. 7, fig. 23.

3. Helicigona. Fer. Ga-

RACOLLA. Lam.

Carinated, somctimes conical.

a Caracolla, Umbilicus covered. Pl. 7, fig. 22; pl. 8, fig.1, 2.

b Vortices, Ocken. Umbilicus masked or visible. Pl. 8, fig. 3.

4. Helicella. Fer. Yol-

TEX. Ocken.

Elliptical or flattened. Umbilicus exposed.

a Lomastomx. Peristoma reflected.PI. 8, fig. 8.

6 Aplostomx. Peristoma simple. Pl. 8, fig. 4.

c Marginatx. Peristoma margined. Pl. 8, fig. 5, 7, 18 ,

(1) Vide p, 30 . 
5. IIclicostyia. Fer.

Elliptical or trochiform. Columella solid.

a Aplostomx. Columella straight; peristoma simple Pl. 8, fig. 6.

b Lamellatx. Columella straight, round; peristoma simple; an internal plate on the last whorl. Pl. 8, fig. 9, 10.

c Canaliculatx. Columella twisted, as if truncated at the base, or with an internal spiral rib forming a gutter, under the form of a tooth or callosity. Pl. 13, fig. 1.

d Marginata. Columella flattened, without teeth or plates; peristoma reflected. Pl. 8, fig. 11 .

6. Helicopianta. Fer.

Spire depressed; volu- Perforated or umbilitions rapidly increasing cate.

horizontally; mouth very large and oblique; only three to three and a half whorls; the last enormous.

a Vitrinoides. Peristoma simple. Pl. 7, fig. 2.

$b$ Vesiculi. Peristoma thickened and sub-reflected.PI. 7, fig. 3, t.

B. Longitudinally polute.

\section{Cochlohydra. Fer.}

Amphibulima. Lam. Suc-

\section{CINEA. Drap:}

Elongated, oval ; voltutions rapidly increasing vertically ; spire short, with 2 to 4 whorls, the last forming almost the whole of the shell; mouth very large. Pl. 6 , fig. 5 . Pl. 7 , fig. 5,6 .

\section{S. Cochlostym. Fer.}

Elongated or ventricose; spire elevated: whorls in- truncated at the base. creasing rapidly.

a Lomastomx. Peristoma reflected. PI. 8, fig. 27.

b Aplostomæ. (1) Peristoma simple.

9. Cochitoma. Fer.

Achatina. Lam.

Conical or very ventri- Columella solid, flat, cose, solid, little transpa- and truncatedat the base. rent.

"Liguus, Hontf. Base conical; mouth short; outer lip advanced. Pl. 8, lig. 26.

b) Achatina, Montf. Ventrical; mouth very large; outer lip vertical. I'l. 13, fig. 3.

(1) The Sullana (Iteli.r Gallina Sullana, Chem.) was sold, at the sale of the Count de Latour d'Auvergne, for 560 francs. 
10. Cocmicopd. Fer.

(Acitativa. Lam.)

Oriform or turreted; Columella solid, flat, thin, transparent; mouth truncated, and arched at nariow. the base.

a Polyphemus, Mlontf. Oviform; mouth long; outer lip rertical. Pl. 8, fig. 22.

6 Styloides. Columna, Perry. Turreted; mouth short; onter lip a little advanced. Pl. 8 , fig. 19.

11. Cochicrlat. Fer.

(Bulimus. Brug.)

Conical or turreted; Columella twisted and perforated; whorls nearly hollow.

equal, or the last shorter than all the others together. P1. 6, fig. 38 .

12. Cochlogena. Fer.

(Auricula. Lam. BuliMus, Lam.)

Oblong or oviform; last Columella hollow, whorl of the spire gene- twisted, straight, perforally longer and larger rated, umbilicate.

than all the others toge-

ther; mouth elongated.

a Umbilicatx. Columella straight. Pl. 8, fig. 20.

b \{ Perforatie. Bulimulus, Lcach. $\}$ Columella twisted. Pl. 6, fig. 28.

c Lomastoma. Bulimus, Lam. Columella twisted; peristoma reflected. Pl. 6, fig. 27.

d Ifelicteres. Turbo, Chemm. Mouth short, crescent-shaped. I'l. 12, fig. 15.

c Stomotoides. Auricula Lam. Mouth elongated, angular at its extremities, or effusive in the upper part; peristoma thickened and reflected; columella large, more or less spiral, sometimes forming a fold in the mouth. Pl. 6, fig. 22, 31 .

$f$ Dontostoma. Mouth crescent-shaped; peristoma margined, a little reflected; colunclla twisted, hollowed, flattened at the base, or forming a protuberance; often perforated. Pl. 8, fig. 23.

13. Cochlodonta. Fer.

(PupA. Lam. Odosto-

sis. Fleming.)

Cylindrical or fusiform; whorls equal, numerous, narrow; mouth short, almost as broad as deep in the direction of the axis; several inner teeth or thin plates; peristoina reflected.

Columella solid or nearly hollow.

a Pupa, Lam. Cylindrical. Pl. 6, fig. 34, 37 ; pl. 8, fig. 32.

6 Chondrus, Cur. F'usilorm. 1'l. 8 , lig. 25 ; pl. 13, fig. 12. 
14. Cocuronisa. Fer. Crausilia. Drap. Yolvulus. Ocken.

Crlindrical or fusiform: whorls equal, numerous, narrow; mouth generally with elevated plates, and alrrays wth one or two gutters.

a Pupoides. Mouth without teeth or plates; peristoma not continuous.

$b\left\{\begin{array}{l}\text { Tracheloides. } \\ \text { Cyclostoma, Lam. }\end{array}\right\}$ Peristoma continuous. Pl. 8, fig. 31.

c $\left\{\begin{array}{l}\text { Anomales. } \\ \text { Pupa, Drap. }\end{array}\right\}$ Mouth without plates. Pl. 8, fig. 29.

d Clausilia, Drap. Mouth with plates. Pl. 6, fig. 36 .

15. Vertigo. Huller.

Cylindrical, rery spi- Peristoma often sinuous ral ; rolute increasing and reflected. gradually; mouth narrow, short in the direction of the axis, often dentated.

a Mouth not dentated. Pl. 8, fig. 34.

$b$ Mouth dentated. Pl. 8, fig. 35, 36 .

16. Partula. Fer.

Oval, pointed; spire Columellar side callous conical; last whorl gib- at base.

bous and longer than all the others together; mouth short in the direction of the axis, sometimes dentated or with elevated plates; peristoma generally much reflected. PI. 8 , fig. 30 . 


\section{SHELLS.}

Shells are enrelopes, formed by a calcareous substance, of a fuliated texture, and almost as heary and hard as marble. They form coverings for a great number of animals of the class of Mrollusca; and every one knows that the variety of their forms, their more or less virid colours, and the brilliancy of their mother of pearl, constitute some of the finest ornaments of the cabinets of virtuosi. Te have sufficiently explained these forms. and we shall presently show their relation with the Orders and Genera of the animals which inhabit them : at present we have only to consider their texture, their gromth, and the manner in which they are united to the rest of the body.

They are composed, like bones, of a calcareous matter : intimately connected with a gelatinous substance, and which may be, in like mamer, scparated by means of acids; but this matter is not disposed in lamina, or in fibres : it is uniformly extended throughout the whole body of the shell.

It is only in some species that we find strata easily separated, and, as it were, agglutinated to each other like the leaves of paper in the formation of pasteboard. We know, from observation, that these strata do not all exist in younganimals; they have only the most external, which are, at the same time, the smallest. In proportion as the animal increases in age, it forms a new stratum on the internal surface of the shell, which extends bejond the edges of all the preceding strata, so that each operation of this hind adds to the size of the shell, in length, breadth, and thickness. These are certain facts; to prove them it is only necessary to compare some shells of the same species that have belonged to indiriduals of different ages; the ferrest strata will always be found in the shells of the young. Muscles, which may be observed when very young, and eren before they quit the matrix of their mother, have, at that period, shells consisting of one stratum only; but the shell is not therefore soft and gelatinous; it possesses the same firmness as the adult shell, and its greater fragility is merely owing to its thinness.

But are the strata which thus successirely augment the dimensions of shells, produced by developement, or by a simple juxta-position? Do the nutritive ressels deposit the calcareous juice at different points, or does it only transude through the skin of the animal, and attach itself to the pre-cxisting strata? These are questions with respect to which physiologists are not agreed.

The bods of the snail appears to adhere to its shell only where the muscles are attached; but Reaumur haring placed thin pellicles between the body and parts of the shell, which he purposcly broke, these fractures were not repaired; but when this, or any other obstacle, no longer prerented the juices flowing from the surface of the skin, the injured part was speedily regenerated.

These facts farour the idea of the simple juxta-position of a transuded matter : we observe, howerer, on the other hand, that the orster and muscle adbere to the shell not only by their muscles, but by the whole border of their mantle; besides, the oyster has always between the two last strata of the convex ralre. a considerable vacuity, which is filled with a fertid acrid liquor, and which communicates with the interior of the body by a particular aperture. How is this racuity produced? and, above all. how is it removed upon the formation of each new stratum, if the arterial and absorbent ressels do not penetrate into the ceutre of the strata, to regulate its position, and to remore, from time to time, the particles of the shell?

Some observations seem to prore that there are testaceous animals. whic!s, 
at certain periods, cast their old shells entirely off, and acquire now ones; but this re-production may also take place by development, as in the horns of the Deer. If the internal strata of those shells which are not cast off, be produced by a developement of this kind, it may be compared to that which forms the internal lamina of the hollow horns of the Ox, Sheep, and other Ruminating Mammalia, and even to that by which the epidermis is produced in all animals; that is to say, there must take place a withering, or, as it were, the death of a membrane, which seems to preserve a sort of organization while it remains unexposed to external elements, or while it has not acquired its proper degree of solidity.

In this manner, it appears, are produced all the hard parts which may be regarded as the bones of animals that have no vertebræ. In cray-fish, for example, the calcareous crust which, in them, is at once skin and skeleton, grows no more after it is completely indurated. The animal, however, conlinues to increase in all its soft parts; and when these become too much confined by the envelope, the latter splits and is detached : but a new covering is found below the old one, which is formed while the latter loses its connection with the lody, and as it were dies. The new envelope is at first soft, sensible, and eren provided with vessels : but a quantity of calcareous particles, previously accumulated in the stomach, is soon deposited in this covering, hardens it, obstructs the pores and the vessels, and renders it in every respect similar to the shell it has replaced.

The induration of the covering of insects is not completed until they acquire their last form, after which they have no longer any occasion to change their skin : but all their skins they previously cast, though soft, are dead, and already replaced by others, which develope themselves underneath that which is destined to fall off.

All the hard parts, therefore, of white blooded animals, whatever may be their consistence and chemical nature, ought to be compared with respect to the manner of their growth to the epidermis, to nails, and to hollow horns, rather than to real bones. 'The same remark should perhaps be applied to certain external parts of fishes, though their substance is strictly osseous; for instance, to the bucklers of the Sturgeon and Cyclopterus, and the spinous tubercles of the Ray.

Some white blooded animals have also hard parts interially; but they are not articulated in such a manner as to form the bases of moveable members, and their texture differs considerably from that of ordinary bones. The most remarkable of these hard parts are the teeth in the stomach of the lobster.

The common Cuttle-fish (Sepia officinalis) contaius in the flesh of the back an oval substance, convex before and behind, white, solid, friable, and of a calcareous nature. 'This substance is not attached to the flesh, but has the appearance of a foreign body introduced into it. 'There is no indication of any ressel or nerve perietrating it, nor is any tendon affixed to it. It is composed of thin parallel lamella, which are not in immediate contact with each other. 'The intervals are occupied by an infinite number of small hollow columns standing perpendicular between one lamella and another; and arranged in a very regular quincunx.

As the superfices of the lamellac are plane, and those of the bone itself convex, they necessarily intersect each other: the points of intersection are marked on the surfaces of the bone by regular cuvilinear strix. 'I hese bones have a lind of wings which are of a less opaque nature, less brittle, and have sreater resemblance to thin elastic horn. than the body of the bone.

To this last substance the parts called the hone in the Calmar (Sepru

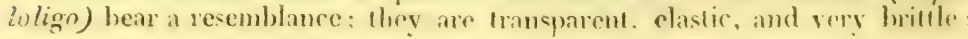




\section{(51)}

their shape is sometimes that of a leaf, and sometimes it is similar to a sword blade. Their comnection with the soft parts is the same as the bone of the Cuttle-fish.

We also find a small semi-corneous and semi-friable plate in the body of the fleshy lobe which covers the branchix of the Aplysia, and there is one still smaller in the cloak of the Slug.

Every thing tends to convince us that those hard parts which are found within Mollusca, grow by strata, like their external envelope, and that they are a kind of internal shells.

\section{Moluusca. Cuvier. (1)}

Without vertebre or articulated nembers; with blood ressels and nerves (2); a simple spinal marrow; lymph, chyle and blood of the same color (a bluish white); generally with salivary glands; a voluminous liver furnishing a great quantity of bile; no pancreas or mesentery; muscles (3) attached to the skin, which forms a soft envelope, contractile, engendering (in several species) stony plates or shells; the viscera and nervous system within this envelope, the latter composed of scattered masses united by nerrous filaments, the principal of which, placed on the oesophagus, are called the brain; a complete system of circulation; respiratory organs; organs of digestion and secretion almost as complicated as in rertebrated animals (4).

(1) Before Cuvier, naturalists divided all the ineertcbral animals into two classes, Insects and IVorms.

(2) Humboldt has adopted an ingenious method of distinguishing the nerres from the arteries, or other parts, in the smallest animals. He uses two needles, one gold, the other silver : a point of one is applied to the muscles, and a point of the other to the filament, the nature of which he wishes to discover, while the other extremities of these instruments are brought in cuntact. If the flament be a nerve, contractions immediately take place in the muscular fibre.

(3) The Mollusca with an exterior shell, as Helices, Bulini, Volutx, ctc. have but one muscle which attaches their body to the shell, by a small part of the back and nearly in the middle of its length. This muscle forms a considerable tendon, similar to a thin ribband, which divides itself into two or three principal ribbands. Each of these subdivides itself into several smaller, which disperse and distribute themselres into all parts of the body. The Mollusca with a univalve shell furnished with an operculum, have two muscles of attachment : one of these muscles unites the animal to its shell and resembles that just described in the univalves without opercula; the other, which adheres to the operculum, is generally round, very wide, but not thick.

(4) The Mollusca with a trunk, as the Buccini, Foluta, etc. are carnivorous; they make use of their trunk as a gimblet. and even bore through other shells and suck the flesh of the animals within. Those which have strong horny jaws and a heak like a parrot, are also carnivorous or nourish themselves with animal substances, like the Cephalopoda. The Mollusca which have a muflle and two jaws, one of which at least is furnished with small tecth, are herbivorous or frugivorous, such as the Limaces, Hclices, Bulimi, etc. 
MOLLUSCA.

\section{CLASSES.}

A. With univalve shells, or none.

\section{Cephinopoda.}

Body in the form of a bag, open before, containing the branchioe.

\section{Pteropoda.}

Body entirely closod.
A head covered with large, long, fleshy productions, serving for locomotion and prehension.

\section{Appendages of the} head small or none; organs of movement two wings or membranous fins on the side of the neck, and frequently bearing the branchial tissue.
Sexes separate.

Hermaphrodite.

\section{Gasteropoda.}

Creep on the fleshy disk of the belly, sometimes

A head distinct and anterior, or none. compressed into a fin (2).
Hermaphrodite and sexes separate.

(1) These are the only Mollusca in which organs of hearing have been discovered, and which have the brain (sending forth innumerable optic nerves from the two ganglions) within a cartilaginous box: they are called Cephalopoda because they have the feet on the head. They have three hearts; they respire in water by branchix; their mouth is placed in the centre of their feet, and resembles a beak; the head is also distinguished by very large eyes, and has the ears placed internally; the stomach is muscular like a gizzard, the liver very voluminous. A particular gland secretes a black liquor, which they throw out, and which darkens the water around them whenever they wish to conceal themselves. They swim with their head behind; and walk in all directions with the head below and the body above. Aristotle remarked, that certain herbs, which have a strong odour, were avoided by cuttle-fishos and the octopus.

(2) They are so called because they crawl on their bellies; the head is moveable, and frequently provided with tentacula; the heart is single.

When the name of the genus appears in the following tables without any clasracteristic particulars, the animal is very imperfectly known. 
B. With bivalve shells, or none.

1. Acephala.

No apparent head; Branchix composed mouth hidden in the bot- of large leaves covered tom or between the folds with vasculary netof a two-lobed mantle work, upon or between containing the branchix which the water passes. and viscera.

\section{BRACHOPODA.}

Mantle lobed; mouth Branchix composed exterior, between the ba- of small leaves, ranged ses of two long fleshy zound the edge of the arms supplying the place inuer face of each lobe. of a foot and with numerous filaments.

\section{Girrhopods.}

With numerous hairy filaments, in pairs, composed of small articulations representing feet or fins, towards the orifice of the shell; mouth at the bottom of the shell.
Hermaphrodite.

Fixed, without the powrer of locomotion. 


\section{CLASS I. CEPHALOPODA.}

\section{GENERA.}

A. No exterior shell.

1. Ocropus. Lam. (Polypus of the Ancients.) (1). PI. 14, fig. 11.

Bag oval, without fins.

8 Feet, very large in 2 Small conical horny proportion to the body, grains on each side of and united by a mem- the back. brane at their base.

2. Lourgo. Lam.

Bag with two fins towards the point. Pl. 14, fig. 1,10 .

8 Feet with little suckers (or short pedi- the back. cles), and two arms to the head, much longer than the feet, with suckers at the end only (2).

3. SEPIA. (3) Lam.

A fleshy fin along each Ditto. side of the bag.

Shell oval, thick, gibbous.

\section{B. Shells interior; chambered.}

4. Spriula, Lam.

Ditto. Pl. 14, fig. 3.

5. Nautiuus.

Ditto.

Mouth with several

A ligament from the circles of numerous back passing througlsmall tentacula without out the syphon, and atsuckers.

taching the animal. (4)

(1) The reservoir for the inh is enchased in the liver. Some believe that the Sepia rugrosa is the species which furnishes the Indian ink. The Mediterranean produces a species remarkable for its musky odour.

(2) They make use of these as anchors.

(3) They lay their eggs allached to one another like bunclies of grapes, whick has given rise to the vulgar name of Sea-grapes.

(4) According to Rumphius; who says that the animal of the Nautilus Pompilius is partly lodged in the last chamber of the shell, and has the bag, eyes, parrot-beak and funnel of the other Cephaloporla. It is also probable that the epidermis is prolonged on the exterior of the shell. 
C. Shells exterior; not chambered.

6. Angonauta. (1)

Ditto.

Two of the tentacula with a membranous enlargement.

(1) The animal uses its shell as a boat, and when the sea is calm it is seen navigating on the surface, employing six of its tentacula as oars, and raising two, which, from the considerable membranous enlargement, serve as sails. Pl. 15, fig. 1 . If the waves are agitated, or any danger appears, the Argonaut draws its tentacula or arms within the shell, concentrates itself, and sinks to the bottom. The ancients were acquainted with this singular animal and its mancuvre; it is their Nautilus and Pompilus. - Plin. IX, cap. 29. Blainville and Dr. Leach consider the animal found in the $A$. argo (PI. 15, fig. 2) to be parasitical, and allied to the Octopus, under the name of Ocythoë. 


\section{CLASS II. PTEROPODA.}

\section{GENERA.}

\section{A. Head distinct.}

\section{Guro. Lin.}

No mouth; head formed by two rounded lobes; tentacula small. PI. 15, branchic. fig. 3.

2. Creodoli. Peron.

Two membranous wing:, with the mouth between, having a small lip.

\section{Cymbulis. Peron.}

A large fin with three lobes, two tubercles and a. small fleshy beard at the base of the smallest.

\section{Lmacrina. (1) Cuv.}

Head and wings resembling those of the Clio: body terminated by a spiral tail lodged in a very thin shell.

\section{Pneumodermov. Cuv.}

Branchix on the surface of the body ; fins small; a small lobe or fleshy tentaculum beneath the mouth. Pl. 15, fig. 4,5 .

\section{B. Head indistinct.}

\section{Ilyarea. Lam.}

Two large wings; man tle cleft at the sides, branchis within the clefts. Pl. 14, fig. 8.
An envelope. Pl. 5. fig. 2 .

Fins with a vasculary

No s'rell.

\section{Envelope cartilagi- nous or gelatinous. Pl. 5 , fig. 3 .}

A shell.
No mantle.

No shell.

(1) This animal also uses its shell as a boat, and its wings as oars, when it swims on the surface of the sea. The species known (Clio IIclicina of Phipps. Gmol. Arsonauta arctica, Fabric Faun. Gront. 387) is scarcely less abundant in the northern seas than the Clio borealis, and, like it, is said to be one of the principal aliments of the whale. 


\section{CLASS 1IJ. GASTEROPODA.}

\section{ORDERS.}

1. Núbranchr. (1)

No shell. P1.15, fig. 7, Branchia naked, dor- Hermaphroditc. 8, 9 . sal.

2. INFEROBRANCH.

Ditto. Pl. 15, fig. 10, Branchiæ naked, un11,12 . der the edges of the mantle.

\section{Tectibranchi.}

Shell more or less developed, within the man-

Branchia covercd by tle. Pl. 16, fig. 1, 2, 3 .

\section{Pulmobranchi.}

A great number with turbinated shells, always without opercula.

A cavity for respiration, opened and shut at will.

\section{Pectinibranchi.}

Shells completely turbinated, and generally more or less closed by the head. I1.13, fig. 18 . an operculum attached to the posterior part of the foot.

\section{Scutibranchi. (2)}

Shells very open, often in the form of a shield, withont opercula. Pl.14, fig. 20.

\section{Crclobranchi.}

Shells of one or several Branchix around the pieces, never turbinated, foot, under the edges of without opercula.

Ditto.

Sexes separate.

Branchix hidden in a dorsal cavity open above
the head. Ill.13, fig. 18 . Sexs separate.

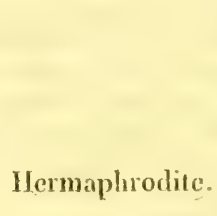
the mantle. PI. 14, fig. 5,6 ,

(1) The greater number swim reversed, the foot (concave like a boat) on the surface, aiding themselves with the edges of their mantle and using their tentacula as oars.

(2) The heart is traversed by the rectum, and receives the blood by two auricles, as in the greater number of bivalues. 


\section{ORDER I. NUDIBRANCHI.}

GENERd.

1. Doris. (1) Cuv.

Branchix posterior, 2 Small conical tenranged in a circle.

tacula to the mouth, and 2 club-shaped from the upper part of the mantle.

\section{Polycera. Cuv.}

Branchix as in Doris, but more simple and with tivo membranous plates covering them in the moment of danger.

\section{Tritonia. (2) Cuv.}

Branchix ranged along the two sides of the back.

2 Club-shaped tentacula before; 4 or 6 others simply pointed.

4. Thethys, Lin.

Two rows of branchix the whole length of the back, like bunches of feathers; a large, membranous, fringed veil on the head.

\section{Scyllata. (3) Lin.}

Body compressed; foot narrow, with a furrow for seizing the stems of Ditto, Mouth a small trunk on the fore part of the mantle.
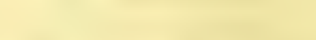

fuci : two pair of membranous crests on the back. Pl. 15, fig. 7, 8, 9 .

2 Compressed tentacula, with a small conical point on the edge.

Ditto,

Mouth like a small trunk.
Mouth a membranous trunk without jaws.
Mouth with large membranous lips.

\section{Glaucus. (4)}

Body long, slim; three or four branchix on each side, formed of long thongs, disposed like fans and serving as fins.

4 Very small conical Swim on their back. tentacula.

(1) $\Lambda$ peculiar liquor issues from a gland interlaced with the lirer. They are found in all seas. Their spawn is spread like gelatinous bands on stones, varecs, etc.

(2) The orifice for the liquor is pierced to the right, and their mouth is armed within by two lateral jaws, horny and sharp, and xesembling shears.

(3) The middle of the stomach is furnished with a fleshy ring, armed with sharp horny blades like knives.

(4) They are beautiful little animals inhabiting the Mediterranean and the Ocean. agreeably coloured with azure and mother of pearl, and swim on their back with great swiftness. They have not yet been dissected, and the species are not very clearly distinguished. 
7. Eoridia.

Branchix like plates or leaves, in transversal rows on the two sides of the back. Pl. 15, fig. 6 .

8. Tergipes. Cuv.

A row of branchix (1) 2 Tentacula. Walk on their back. along each side of the back.

\section{ORDER II. INEEROBRANCHI.}

\section{GENERA.}

1. Phyllidia. (2) Cuv.

Mantle naked, generally coriaceous. Pl. 15 , fig. $10,11,12$.

1 Tentaculum on each side of the mouth, and 2 from above the two small cavities of the mantle.

2. Diphyllidra.

Mantle more pointed behind : head semicircular.

1 Pointed tentåculum and a slight tubercle on each side of the head.

(1) These are each terminated by a little sucker, and serve as fect fur walking on the back.

(2) Their heart is towards the middle of the back, the stomach is simple and membranous, and the intestine short. 


\title{
ORDER III. 'TECTIBRANCHI,
}

\author{
GENERA.
}

\section{Pleurobranchus. Cuv.}

Body as if between two shields formed by the foot and the mantle; the latter sometimes containing an oval calcareous plate.

\section{Aplysia. (2) Lin.}

Edges of the foot turned up, flexible, encircling the back in every part: head borne on a neck. Pl. 14, fig. 2, 11,*14.

\section{Dolabella. Lamr.}

Body resembling a truncated cone; shell calcareous.

\section{Notarchus. Cuv.}

Mantle with an oblique cleft above the neck communicating with the branchixe.
2 Tubulous and cleft tentacula on the mouth (a small trunk), surmounted by a lip.

2 Superior tentacula, hollowed like the ears of a quadruped, with the eyes at the base; ' 2 others flattened and at the edge of the lower lip.
Branchix along the left side, in the furrow between the mouth and the foot.
Ditto.

Branchix at the posterior extremity of the body.

\section{Brauchix on the back} and attached to a stem covered by a small membranous inantle, containing a hollow flat shell.

Ditto.

Branchixe as in Aplysia.

(1) They have four stomachs; the second is fleshy, sometimes armed with bony pieces, and the third furnished interiorly with lungitudinal projecting plates; the intestine is short.

(2) An enormous membranous crop conducts to a muscular gizzard, armed with. in by pyramidal, cartilaginous corpuscles, followed by a third stomach sown with sharp crooks, and a fourth in the form of a cocum : the intestine is roluminous. These animals feed on fucus. A peculiar gland furnishes, by an orifice situated near the womb, a limpid humour, which is said to be sour in some specics; a deep purple liquor issues abundantly from the edges of the mantle, with which the animal colors the water to a considerable distance on the approach of danger. When Apuleius was accused of magic and poisoning, it was reported as a principal evidence that he had engaged some fishermen to procure him an Aplysia (ScaIIare); and it is to the following part of his description that we owe the only characteristic which has enabled us to recognise so celebrated an animal. "It has an extraordinary property, of which my predecessors have been ignorant, which is, that being otherwise destitute of bone, it has twelve small ones in its belly, similar to the astragali of the hog, attached and tied together." The form of the Aplysia explains the name of Sca-IIarc; and their smell, and the liquor which they froduce, account for the pernicious properties attributed to them. 
5. AkERA. (1) Muller.

Tentacula so short and broad as to appear wanting or replaced by a fleshy rectangular shield. $\mathrm{Pl}$. 16, fig. 1,2, $3,4,5$.

\section{ORDER IV. PULMONACEA.}

\section{GENERA.}

\section{A. Terrestrial; shell interior; almost all with 4 tentaculs.}

1. Lmax. (2) Lin.

Borly elongated ; a Orifice of respiration fleshy disk instead of a on the right side towards mantle, anterior and co- the front.

rering the pulmonary cavity only. Pl. 13, fig. 18. Pl. 15, fig. 13.

2. Testacella. (3) Lam.

Mantle very small, posterior. Pl. 16, fig. 18.

Orifice of respiration posterior.

3. Parmacelita. Cus.

Mantle membranous, Orifice of respiration with the edges flaccid. under the right side of Pl. 14, fig. 9. PI. 16, fig. the middle part of the 9. mantle.

B. Terrestrial; shell exterior; almost all with 4 tentacull.

4. Vitrina. Drap. HeLLCo-Lnax. Ferus. (4)

Body protected in front Body too large to enby a sort of cuirass, and ter entirely within the behind by a thin shell shell. which may be partly corered by the lobes of the collar or mantle. PI. 14, fig. 12.

(1) Their hermaphroditism, the position of their two sexes, the complication and armour of their stomach, the purple liquor produced by several of their species, approach them to the Aplysia.

(2) Their mouth has only an upper jary, in the form of a dentated crescent, which enables them to gnaw herbs and fruits.

(3) The T. haliotidea lives under ground, and feeds principally on worms. M. de fierussac has observed, that its mantle expands extraordinarily when it is in too dry a place, affording it a sort of shelter.

(t) The mantle has a double edge; the upper, which is divided into several lubes, can extend far beyont the shell, and fold back to rub and polish it. 


\section{Helicarion. Ferus.}

Body truncated behind, with a cuirass in front, under the anterior edge of which it retires its head : shell posterior ; foot separated from the body by a furrow and with a mucous pore at its extremity. Pl. 14, fig. 7. Pl. 16, fig. 6.

\section{Helix. (1) Lin.}

Body with a muscular disk or foot, sometimes pediculated, more or less gibbous and spiral above.

Nantle forming a kind of ring or collar (at the point of junction of the two parts of the body), in which is pierced the round orifice of the respiratory cavity.
Head indistinct, with two pair of retractile tentacula, the posterior the larger, and bearing the eyes at the summit; mouth with a pair of short appendages.

a. Bulimus, Lam. (2)

b. Pupa, Lam.

c. Scarabæus, Montf.

d. Chondrus, Cuv.

c. Amphibulima, Lam.

(3) Inferior tentacula very small.

f. Clausilia, Drap. (4)

g. Achatina, Lam. (5)

(1) V.p. 74.

(2) Large and beautiful species are found in warm countries : some are remarkable for the size of their eggs, the shell of which is stony ; and others for their sinistral shell. The IIelix decollata has the singular habit of breaking the whorls at the top of its spire, proving that the muscles of the animal can detach themselves from the shell without injury, and that they adhere to different points of the shell successively. How is it that they thus effect the separation of the vessels from one part to implant them in another? for it sometimes happens that this IIclix or $B u$. limus has but one of the original whorls of its spire left. Some species of Pupa, Clausilia, and Mclania are found in the same state. The Kambcul of Adanson appears to pass the dry season in a deep trance, like the Limax of Europe, for he found several half buried after the month of September. Some had even already began to close the mouth of their shell with a whitish plastery matter, to defend themselves from the long drought, which continues at Senegal from October to the following June.

(3) This animal may perhaps be considered as a Testacella with a large shell. Its inferior tentacula are very small, and it lives on herbs and bushes by the side of streams, which has caused it to be thought an amphibious genus.

(1) In the narrow part of the last whorl we generally find a small plate, slightly curved like an $\mathrm{S}$ : its use to the antmal is unknown.

(5) At the extremity of the truncated columella we find the first indication of the notches in the shells of the marine Gasleropoda. 


\section{Aquatic; 2 tentacula.}

Without a shell.

\section{Oncmivim. (1) Bu- chanan.}

A broad fleshy mantle. Il. 16, fig. 8.

2 Long retractile tentacula, and two triangular lips.
Orifice of respiration under the posterior part of the mantle.

With shells.

6. Ancrus. Geof:

Eyes at the inner base of the tentacula.

7. Playonis. (2) Brug.

Pl. 16, fig. 10.

Tentacula thin, fili- Ditto. form.

7. Lymates. (3) Lam.

Tentacula compress- Eyes near the base of ed, broad, triangular. the inner edge.

8. Piysa. (4) Drap.

Two dentated lobes to the mantle.

Tentacula thin, pointed.
Eyes at the inner base, which is much enlarged.

9. Auricula. Lam.

10. Conovura. Lam.

11. Torxateila. Lam.

12. Prramideli. Iam.
Animals unknown, but (from the form of the shell and the absence of the operculum) approximating to the Auricula.

(1) The mollusca, destitute of jaws, have a muscular gizzard, followed by two membranous stomachs.

(2) $A$ red and abundant liquor exudes from the edges of its mantle, but it is not their bluod; they are the constant companions of the Lymnai in all stagnant waters.

(3) We find them floating on the surface of the water with the foot turned upwards, and very rarely ereeping on hard substances; when disturbed they fall or sink, and remain a long time immoveable before they reappear at the surface.

(1) This animal, when it swims or creeps, corers its shell with the two dentated lobes of its mantle. 


\section{ORDER V. PECTINIBRANCHI.}

\section{FAMILIES.}

\section{Trochoїㅅ.}

Shell spiral, mouth entire, without notch or canal. Pl. 9, fig. 7.

2. BücinoÏDA.

Shell spiral, with a notch or canal for the passage of the siphon, which is a prolonged fold of the mantle. Pl.10, fig. 21.

\section{Sigaretoïda.}

Shell flattened, hidden during life within a spongy buckler which is the true mantle. Pl. 5, fig. 25. PI. 14, fig. 15, 16. 


\section{FAMILY I. TROCHOÏDA.}

\section{GENERA.}

1. Tunbo. Lin.

Shell turbinated. mouth round.

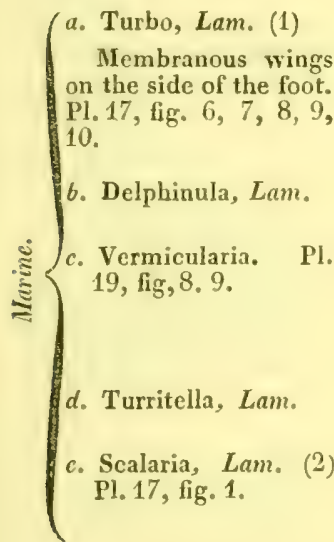

2 Long tentacula.

2 Triangular, flattened, Ditto. small tentacula.

2 Long, slim tentacula. Ditto.

(1) To these belong the thick, strong opercula, so frequently found in collections, which were formerly employed in medicine under the name of unguis odoratus.

(2) The mouth is encircled by a callous pad, which the animal repeats from space to space as its shell increases, so as to give the appearance of ladders. 


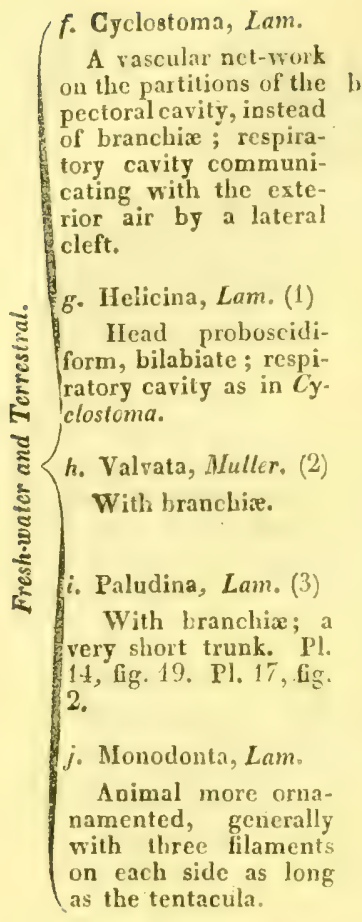

2 Tentacula terminated by blunt tubercles.

2 Filiform tentacula.

2 Slim tentacula.

2 Pointed tentacula.
Eyes on two tubercles near the base of the tentacula.

Eyes at the outer base.

\section{Trochus, Lin.}

Mouth of the shell ansular, more or less quadrangular, oblique to the asis.

a. Trochus.

Three filaments at each edge of the mantle, or appendages to the foot. Pl. 17 , fig. 3 , $4,12^{*}, 13$. base.

Eyes at the superior

Eyes at the outer base.

\section{b. Solarium.}

(1) M. Blainville is convinced that this is the place of the Ilelicina: but MI. de Ferussac says that it has a collar, with the respiratory hole pierced to the left.

(2) In the $V$. cristata the branchix, formed like a feather, proceed from underneath the mantle, and float beyond it with a vibratory motion when the animal wishes to breathe; on the right side of the body is a filament resembling a third tentaculum.

(3) The female of the $\boldsymbol{P}$. vivipara produces living young, which are found in her oviductus, in the spring, in all the stages of developement. Spallanzani asserts that these young separated at the moment of their birth, and nourished apart, repro. duce without fecundation like those of the Vine-fretter. The $P$. cristata one of the small species found in salt water ponds, and described by M. Beudant, moves its tentacula incessantly as oars when it gails on the surface of the water. 
3. Cosenrlum. Cur.

Entirely aquatic or breathing by branchia.

a. Ampullaria.
Animal not yet de. scribed, but probably re. sembling the Paludina.

Animal not well known.

c. Phasianella.

Double lips notched and fringed, each wing with three filaments.

2 Long tentacula.

Eyes on two tubercles at the outer base of the tentacula. d. Ianthina. (1)

A resicular organ un. der the foot, like a fro. thy ball but solid, which admits of floating but not of creeping; head like a cylindrical trunk, mouth with little fangs. Pl. 14, fig. 13.

4. Nerita. Lin.

Shells with the columella straight, the mouth semi-circular or semi-elliptic, and closed entircly by an operculum.

\section{a. Natica, Lam.}

Foot large; operculum horny. Pl. 17, fig. $17,18$.

\section{b. Nerita, Lam. (2)}

Foot moderate; operculum stony. Pl. 17, fig. 11, 12 .

\section{c. Neritina.}

Foot moderate; oper. culum borny.
Tentacula simple.

Eyes at the base of the lentacula.

Eyes on stems at the side of the tentacula.

(1) The common species (IIelix Ianthina, Lin.) List. 572,24 , is a pretty violetcoloured shell, abounding in the Mediterranean. When the animal is touched, it sheds a thick liquor of a deep violet colour, which tints tbe sea around it.

(2) The opercula of some univalve sbells, particularly of the Nerita, are articulated by ginglymus. 


\section{FAMILY 11. BUCCINOIDDA.}

GENERA.

\section{Coxus. Lin.}

Trunk elongating considerably ; operculum placed obliquely on the foot, narrow, too short to close the mouth of the shell; a long respiratory tube. Pl. 16, fig. 12.

\section{Crprea. (1) Lin.}

Mantle large enough to curl up and envelope the shell : foot thin; no operculum. $\mathrm{Pl}$. 16, fig. 11 .

3. Ovula. Brug.

\section{Terepejlum. Lam.}

\section{Voluta Lin.}

Shell terminated by a notch, with projecting and oblique folds on the columella. Pl. 18, fig. 1,2.

\section{a. Oliva, Brug.}

A tube above the head for respiration.

\section{b. Voluta.}

An elongated trunk, cylindrical and retractile, with small crooked teeth; a respiratory tube projecting obliquely behind the head; foot very large ; no operculum. PI. 18, fig. 2 .

\section{c. Cymbium.}

A very large foot; no operculam. PI. 18, fig. 1 .
Tentacula elongating considerably.

Tentacula moderate.
Eyes near the points on the outer side of the tentacula.

Eyes at the outer base.

(1) The mantle is sufficiently large to turn back upon the shell and envelope it ; at a certain age it covers the shell with a layer of another colour, so that this differ. ence, added to the form assumed by the aperture, might cause the adult to be taken for another species. V.p. 41. 
d. Marginella.

Foot very large, part. ly covers the shell by raising the lobes of the mantle; a retractile trunk, a respiratory tube above the head; no operculum.

c. Mitra.

f. Cancellaria.

6. Buccinum.

Shells without folds on the columella; with a notch or short canal inflected torvards the left. for the passage of the respiratory tube. Pl. 10, fig. 21.

\section{a. Buccinum.}

No veil to the head; a trunk; a respiratory tube formed by the mantle ; operculum horny. Pl. 17, fig, 15, 16. Pi. 13, fig. 16,19 , 20.

\section{b. Eburna, Lam.}

c. Dolium, Lam.

d. Harpa, Lam.

c. Nassa, Lam.

Tentral disk enlarged, truncated anteriorly, prolonged beyond the head; a tube above the head formed by the mantle.

\section{f. Purpura, Brug. (1)}

Foot elliptical ; respiratory tube prolong. ed above the head; operculum cartilaginous. Pl. 17, fig. 14.
Eyes on the outer base of the tentacula.
2 Conical tentacula far apart.

2 Puinted tentacula.

Eres on the outer side of the tentacula.

Ditto.

Eyes in the middle of the outer part of the tentacula.

(1) The animal furnishes a matter fit for dying red, which the ancients used, and which is still employed in the north of Europe. 
g. Cassis. Brug.

Animal resembling the Buccinum, but the operculum horny and dentated in order to pass between the wrinkles of the outer lip. Pl. 18, fig. 7 .

\section{h. Cassidaria, Lam.}

Animal resembling the Buccinum.

\section{i. Terebra, Lam.}

\section{Cermtinum.}

Shell with a turreted spire, mouth oval, canal short, curved to the left or backwards ; operculum

A veil on the head.

Two tentacula, far apart, with the eyes at the side.
No veil.

2 Long tentacula, neas to each olher, with the eyes at the extcrior side.

a. Murex, Lam.

A retractile trunk; a tubulous prolongation of the mantle; operculum small, horny. Pl. 18, fig. 4, 6. Pl. 19, fig. 2 .

b. Ranella, Lam.

c. Fusus, Lam. Pl. 18, fig. 5.

d. Turbinella, Lam.

c. Pleurotoma, Lam.

f. Pyrula, Lam.

g. Fasciolaria, Lam.

9. Stromeus. Lin.

Canal straight or inflected towards the right; lip dilating with age but preserving a sinus near the canal, under which the animal passes its head.

a. Strombus, Lam.

Operculum horny, long, narrow; foot small. Pi. 19, fig. 1.

b. Pterocera, Lam.

r. Rostellaria, Jam. 


\section{FAMLY HI. SIGAREIOIDDA.}

GENERA.

1. Sigaretus. Cev.

A notch and semi-canal in front, conducting the water into the branchial cavily. Pl. 14, fig. 15, 16.

Tentacula conical.

Eyes at onter base of the tentacula.

\section{Cinprostons. Blains.}

Foot enormous, four or live times larger than the body; mouth hidden unTentacula short, conical, with appendarges at the base.

der the anterior edge of

the shell.

\section{ORDER VI. SUUTHBANCHI}

\section{GENERA.}

1. Haxoms, Lin.

Shell turbinated. P1. 5. fig. 21 .

a. Inalyotis. Lam. (1)

Mouth a short trunk. Pl. 13, fig. 21. Pl. 14, fig. 20 . Pl. 19, fig. 3 , 1,5 .

\section{b. Padolla.}

c. Stomatia. (2)

2. Cisulus. Monlf.

Shell conical ; branchise on the anterior edge of the cavity: trunk rather

Tentacula lon:, some at the edges of the cavity of the branchix, and pass. ing through the last holes of the shell.

lorig; a folded membranous veil under the neck. Pl. $16, \mathrm{fig}$. 7 .

2 Gonical tentacula.

Eyes on the outer base of the tentacula.

(1) The mantle is deeply cleft on the right side, and the water which passes through the holes of the shell, proceeds by this cleft into the branchial cavity. There are three or four filaments along the edges of the mantle, which the animal has tire power of pushing out through the holes.

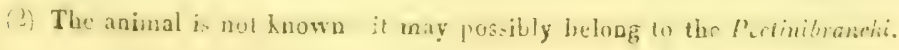


3. Cheproura iam.

Shell with an oval base; the abdominal bag) containing the viscera) on the plate of the shell; the foot beneath; the head and branchia in front. Pl. 16, fig. 15, 16, 17.

Shells, and the position of the heart and branchio, symmetrical.

4. Fissurella. Lam.

A conical shell on the middle of the back, with a small hole at the summit (for the passage of the water for respiration) extending to the cavity of the branchize on the fore part of the back; a branchial comb on each side; with filaments on the sides of the foot. Pl. 16, fig. 14. Pl. 19 , fig. $6,7$.

5. Emarginula. Lam.

A fissure instead of a hole, for the same purpose; edges of the mantle covering a great part of the shell. Pl. 16, fig. 13.

6. Septaria. Fer. NaviCELLA. Lam.

A moveable, angular,testaceous plate (besides the shell) hidden in the back of the abdominal bag.

7. Carinaria. (1) Lam.

A compressed, muscular portion under the belly, serving as a fin; shell attached on the branchix; a trunk; head furnished with tubercles. P1. 14, fig. 17.

\section{Calyptren. Lam.}

(1) The skin of these animals is almost gelatinous, and has a layer of fibres under it, which, when they are taken, contracts so much as to tear the body and let out the intestines.
2 Conical tentacula.

Eyes at the outer base of the tentacula.
Eyes on a tubercle at the outer base of the tentacula.
2 'Tentacula.
Eyes at the base of the ientacula. 


\section{ORDER VII. CYCLOBRANCHI.}

\section{GENERA.}

1. Patella. (1) Lim.

Shell of a single piece; a cord of small branchial

2 Pointed tentacula.

Eyes at the outer base of the tentacula. leaves under the edges of the mantle; a thick, short trunk. Pl. 14, fig. 5, 6 .

2. Сhiton. (2) Lin.

A range of testaceous, ; $\mathbf{\Lambda}$ membranous reil symmetrical scales along on the mouth instead of the back of the mantle. tentacula.

(1) The mouth is fleshy, and contains a spiny tongue, lengthened posteriorly, and folded deeply within.

(2) The slecll of the Chiton will be figured and described with the Mullivalves. 


\section{SYNOPTIG TABLE}
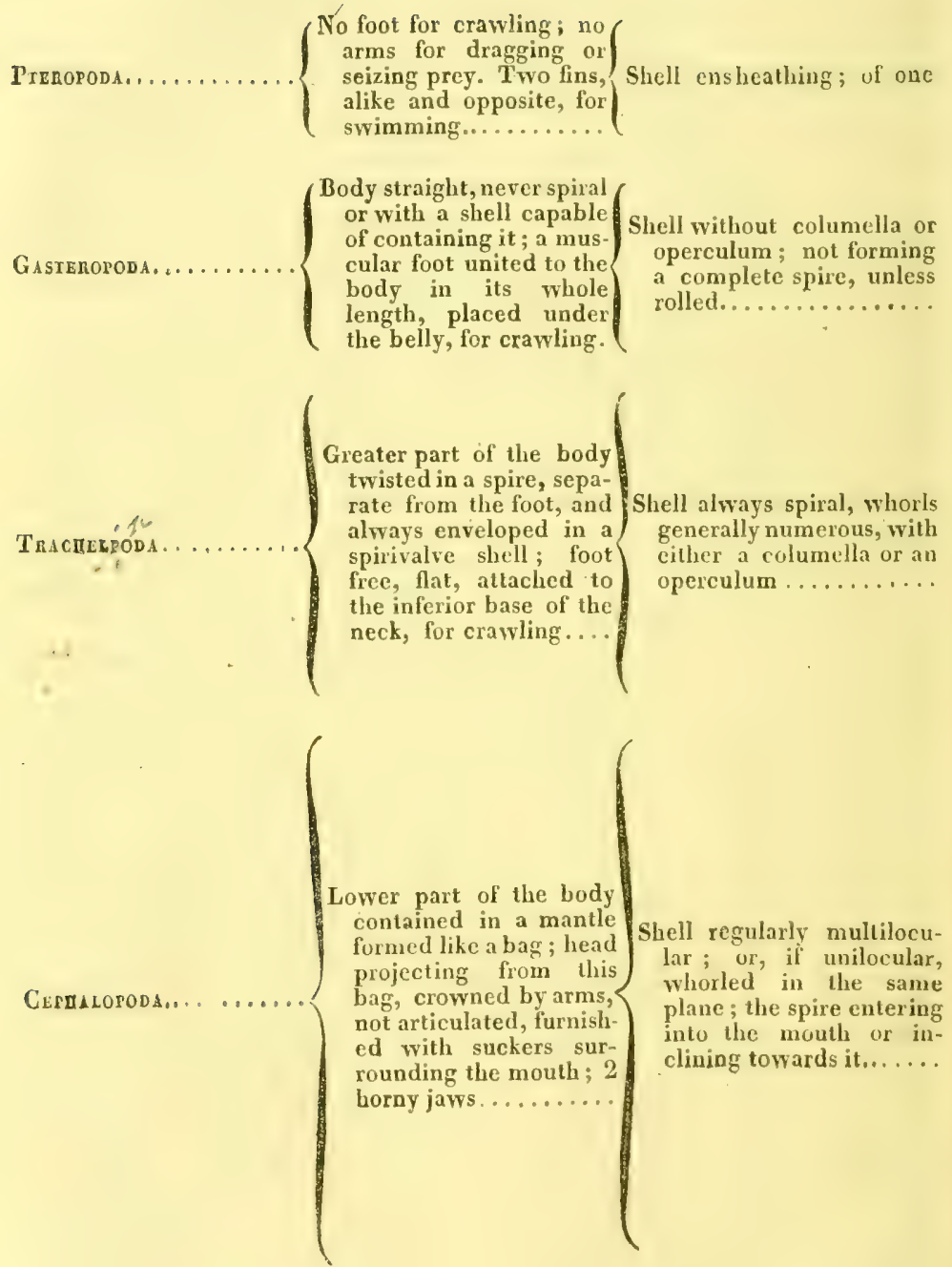


\section{OF LAMIRCK'S SYSTEM.}

piece, never spiral, always exterior.

Shell exterior, covering: in one piece in the form of a shield, cap, or sandal; or in several imbricated pieces: imperfectly or not at all $\} 2$

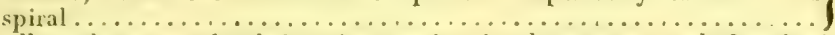

Shell partly or completely interior; cavity simple or none; only forming a spire when the whorls completely cover each other............

Shell exterior; not capable of entirely containing the animal; the spire ? imperfectly formed of two whorls......................

Mouth of the shell entire; no notch or canal at the base.......... 5 .

A channel more or less long at the base of the shell; outer lip not changing with age ...............

A channel more or less long at the base of the shell;

Shell channelled outer lip changing its form with age and having a

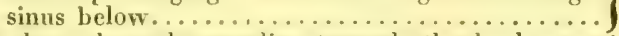

A short channel ascending towards the back, or an or notched, or cllusive at its oblique notch sub-ascending at the base of the shell. basc.

No channel, a notch at the base of the mouth; folds on the columiella....................... No channel, the base of the mouth notched or effu-
sive; the whorls large, rolled round the axis...... Inroutr.

6. Ganaliferx.

7. ALAtE.

8. Porpurifera,

9. Columellate.

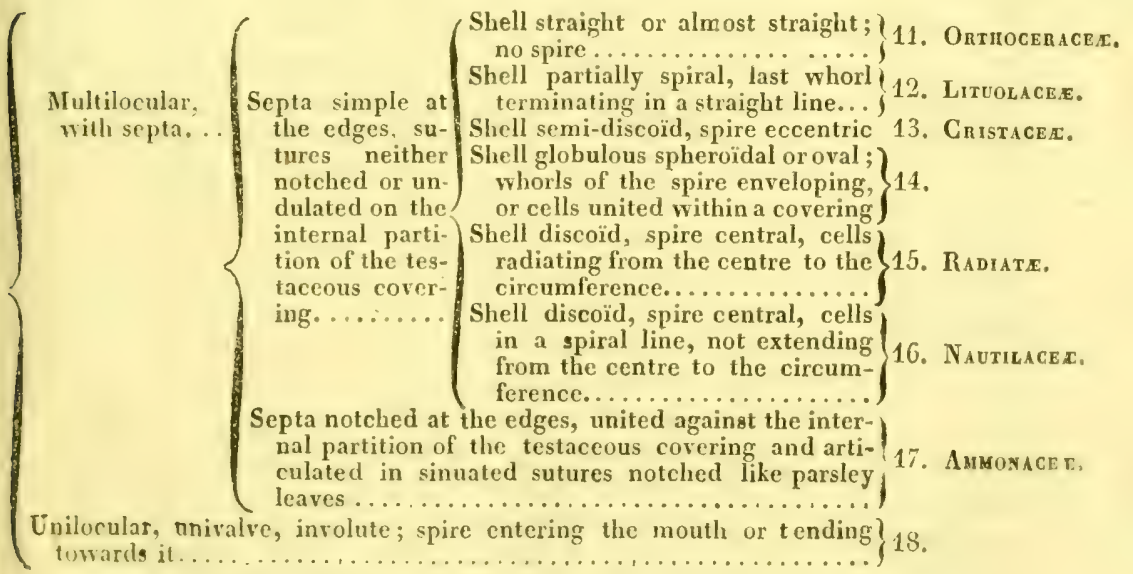

$$
\text { - V. Note, p. } 27 \text {. }
$$



Acephala . ....... Page.

Achatina......... 28

A $-\ldots \ldots \ldots .46$

-

- -........ 62

Aciona .......... 33

Actxon.......... 29

Agathina......... 28

Akera.......... 43

- ........... 61

Amaltes......... 22

Ammonaceratites... 21

Ammonites....... 22

Amphibulima ...... 29

- - - - .... 46

- -..... 62

Amplexites ........ 17

Ampullaria ....... 31

Ampullina . ........ 31

Anastoma........ 31

Ancilla.......... 38

Ancillaria........ 38

Ancylus.......... 24

Angulites........ 22

Aplysia......... 43

.......... 60

Apollo............36

Aquila......... 36

Arethusa......... 16

Argonauta....... 23

Auricula $\ldots \ldots \ldots \ldots . .28$

- $\ldots . . . . .47$

Baculites ......... 18

Batholites ........ 18

Belemnites....... 17

Bisiphites........ 22

Brachiopoda ..... 53

Brontes........... 36

Buccinoüda........ 64

- - -......... 68

Buccinum........ 39

69

Bulimopsis........ 29

Bulimulus........ 29
Page.

Bulimus ......... 29

47

-

Bulla......... 43

Bullac......... 43

Galmar.......... 14

Calyptrac........ 25

(

Camerina........ 15

Cancellaria........ 40

- -........ 69

Capulus........... 25

- $\ldots . . . \ldots .71$

Caracolla........ 31

- - ....... 45

Carinaria ........ 23

$7^{2}$

Carychium........ 28

Cassidaria......... 40

- - - ....... 70

Cassis........... 41

70

Gephalopoda....... 52

Cerithium......... 38

- - -........ 70

Ghicoracex........ 36

Chiton........... 73

Chondrus........ 30

- - - ........6. 62

Cirrhopoda........ 53

- - - -....... 51

Cirrites........... 35

Clavatula......... 37

Clausilia.......... 29

- _ ......... 48

- — . . 62

Cleodora.......... 23

-............. 56

Glio............ 56

Gochlicella....... 47

Cochlicopa........ 47

Cochlitoma........ 46

Cochlodina......... 48

Cochlodonta ...... 47

Gochlogena....... 47

Gochlohvdra ...... 46

Cochlostyla....... 46

Columbella...... 42
Page

Concholepas ...... 40

Conchylium...... 69

Conoelix........ 41

Conovulus ......... 28

$\longrightarrow \ldots 63$

Conulantes........ 17

Conus.......... 43

- ..............6. 68

Cornucopia........ 18

Crepidula......... 25

- - _......... 72

Cristellaria........2 21

Cryptostoma...... 71

Cyclostoma....... 34

- - - ....... 66

Cyclobranchi...... 57

一一一 ...... 73

Cymbium........ 41

68

Cymbulia......... 23

- — ........ 56

Cypraca. ....... 41

$-\ldots \ldots . . .686$

Delphinula....... 23

-

Diphyllidia........ 59

Discorbites........ 15

- _ _....... 22

Dolabella ......... 44

-

Dolium........... 39

69

Doris........... 58

Ehurna......... 38

- - .........6 69

Fllipsolites....... 22

Emarginula ........ 24

- - - ...... 72

Eolidia.......... 59

Euomphatites..... 35

Fasciolaria........ 37

- - ....... 70

Fissurella......... 24

- - - ....... 72

Fusus ............. 36

70 


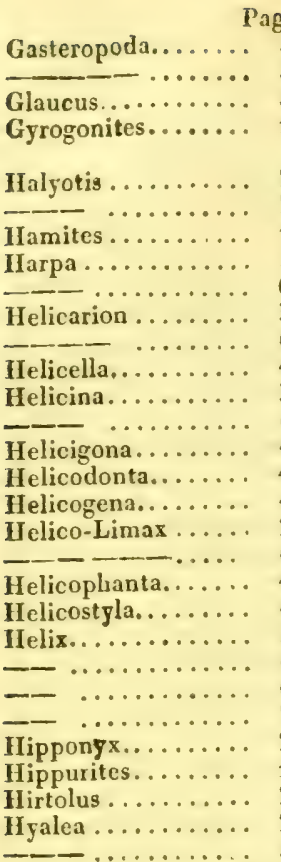

Ianthina........ 35

Inferobranchi..... 57

Infundibulum ..... 25

Laplysia ......... 43

Lathires......... 36

Lenticulina ....... 22

Liguus.......... 28

Limacina ........ 56

Limax........... 61

Lituites.......... 20

Lituus........... 20

Loligo........... 14

- $\ldots . . . . .55$

Lotorium . . . . . . . 36

Lymnxus ........ 27

Marginella ....... 42

__....... 69

Melampus........ 28

Melanamona ...... 28

Melanatria........ 28

Melanella........ 27

Melania.......... 27
Page.

Melanopsis.......27

Melantho ......... 27

Meleager......... 33

Melonites ......... 16

Miliola........... 16

Mitra............ 38

-

Monoceros....... 40

Monodonta........ 34

-

Morio............ 40

Murex........... 36

70

Nassa........... 40

-

Natica.......... 32

- _.......... 67

Nautilites........ 22

Nautilus......... 22

- - ......... 54

Navicella........ 25

- —........ 72

Nerita.......... 32

- - ........ 67

Neritina....... 32

- — $\ldots \ldots . . .6 .67$

Nodosaria........ 17

Notarchus........ 60

Nudibranchi....... 57

- - - ...... 58

Nummula........ 15

Octopus......... 54

Odostomia........ 30

Oliva........... 41

- - .......... 47

-

Onchidium.......6.63

Orbulites.......... 22

Orthoceratites..... 17

Ovula........... 43

- .......... 68

Padolla.......... 26

- - -.......... 71

Paludina.......... 34

Parmacella.............. 26

___........ 61

Parmaphora....... 24

Partula .......... 48

Patella........... 21

-

Pectinibranchi..... 57

- - _ _..... 61

Phasianella........ 28

—_-.......6 67

Phyllidia.......... 59

Physa......... 27
Page.

Physa ......... 63

Planorbis........ 30

Planospirites...... 54

Planulites......... 22

Plectrophorus ..... 24

Pleurobranchus..... 44

Pleurotoma........ 37

70

Preumodermon..... 56

Pollontes.......... 16

Polycera.......... 58

Polyphemus....... 28

Polypus.......... 5t

- - .......... 56

Potamides....... 39

Pterocera......... 43

70

Pteropoda........ 52

Pulmobranchi ..... 55

Pulmonacex...... 61

Pupa........... 30

- $\ldots \ldots \ldots \ldots .47$

- $\ldots \ldots \ldots \ldots .62$

Purpura ........ 40

- $\cdots \cdots \cdots \ldots .69$

Pyramidella....... 38

Pyrula.......... 37

70

Ranella.......... 36

-

Renulites........ 15

Ricinella......... 40

Rostellaria....... 39

70

Rotalites........ 22

Sealaria.......... 33

- - .......... 65

Scaphites....... 20

Scarabeus ....... 28

- - - ....... 62

Scutibranchi...... 57

- - ..... 71

Scutus.......... 21

Scylla......... 58

Sepia........... 14

-

Septaria......... 24

Siderolites ........... 15

Sigaretoïda.......6t

Sigaretorda........... 71

Sigaretus ......... 26

- _ ....... 71

Solarium......... 35

$-\ldots \ldots \ldots \ldots 60606$ 
I N D EX.

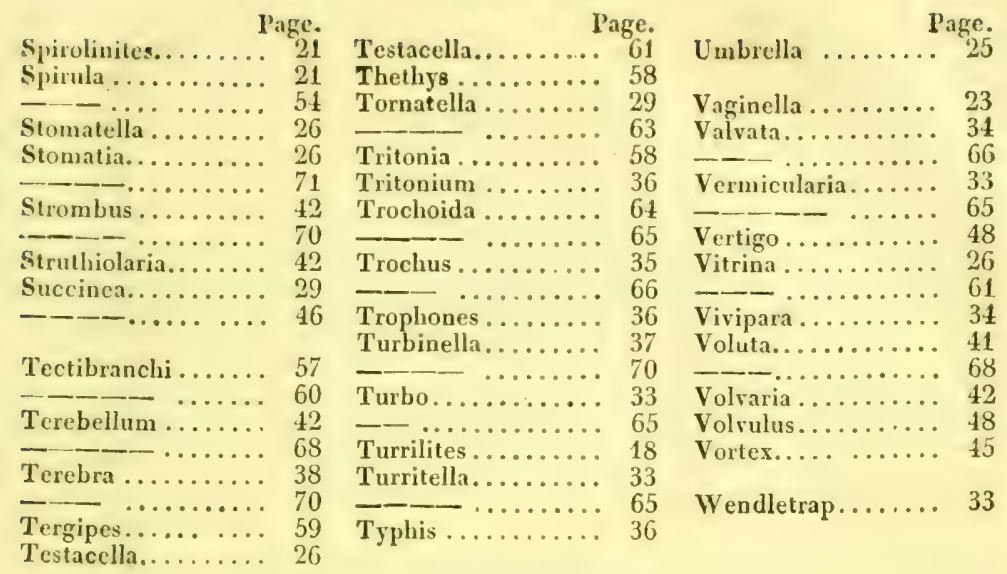





\section{BY THE AUTHOR.}

An ANALYSIS of the NATURAL GLASSIFICATIONS of MAMMALIA, including the Systems of Cuvier and Illiger, and illustrated by upwards of 200 figures (comprehending the Estinct or Fossil Genera and Species), principally from the objets themselves in the Gallery and Cabinet of Comparative Anatomy of the Jardin des Plantes. Price 15s.

An INTRODUCTION to the ORNITHOLOGY of CUVIER, illustrated by 261 figures (including several anatomical), principally from the objects themselves, and drawn off on tint. Price $15 \mathrm{~s}$.

These two works have been adopted as text books by Professor Jamieson of the Edinburgh University.

An ESS AY on the SUPERSTITIONS, CUSTOMS, and ARTS common to the Ancient EGYPTIANS, ABYSSINIANS and ASHANTEES : with coloured figures of part of the objects of manufacture presented by the Author to the British Museum. 4to. Price 8s.

It is presumed that this little Essay will prove, by a variety of curious Evidence, that $\mathrm{Abysinia}$ is not the only part of Africa which has been partly civilised by an intercourse with colonists and emigrants from ancient Egypt, and that much light may be reflected on Antiquity as well as Natural Ilistory and Physical Science, by pursuing the British Discoveries in the interior of Africa, gradually apd in detail.

An ENQUIRY into the BRITISH and FRENCH EXPEDITIONS to TEEMBO, with remarks on Givilisation in Africa. Price 2s.

An ESSAY on the GEOGRAPHY of NORTH WESTERN AFRICA, with a 2-sheet lithograplic map, constructed by the Author from original Itineraries, and detailing the Arabic Itinerary from Aslantee to Mecca, which was mislaid at the time of the publication of the Mission to Ashantec. Price 10s. 6d.

" M. Bowdich a donné à part une carte speciale du pays des Aschantis, basee " sur ses propres observations, sur des itinéraires détaillés et sur la comparaison " qu'il en a faite avec les cartes de d'Anville et les relations des autres voyageurs. "Cette partie de son travail, ainsi que ce qu'il a donné sur les environs de Gaboon, " sont des acquisitions précieuses pour la géographie. Le reste de la carte de " M. Bowdich est beaucoup plus hypothétique, et se fonde sur des documents plus " incertains. - Malgré tant de causes d'imperfection, la carte de M. Bowdich " sera utile, parce qu'a beaucoup de sagacité l'auteur a joint une profonde étude " de son sujet, et qu'elle offre des recherches, des rapprochements curieux, et des " conjectures probables, présentés d'une manière claire et méthodique. Tout ce "que M. Bowdich écrira sur l'intérieure de l'Afrique, sera toujours un objet "d'attention pour tout homme instruit."-IFalckenacr (Président de l'Académie des Inscrip. et des Belles Lettres) Recherches sur l'Afrique, p. 326, 330, 314.

The GONTRADICTIONS in PARK'S LAST JOURNAL EXPLAINED, and his Astronomical Observations in 1796 re-established, by the corrections necessitated by his having reckoned on the 31st of April.

The ELEMENTS of ALGEBRA, with Historical and Explanatory Notes, and a Supplementary Volume containing calculations and notes for the aid of Students (who are out of the reach of a Tutor) in reading Le Gendre's Trigonomeiry, Biot's Analytical Gcometry, La Croix's Calcul Differentiel et Interral, and Poisson's Mechanies.

During a residence of two years and a half at Paris, with the view of perfecting 
limself in Mathematics and Physical Science, as necessary for the greater scientific results of a second travel in Africa, the Author has had occasion to read the greater number of the French works on the elementary parts of mathematics, and to compare them with our own. Ife was astonished to find that England, which has produced Harriot, Wallis, Barrow, and Newton who may be considered as the father of analysis; that England, possessing at the present moment so many illustrious men of science, does not afford elementary books enabling students to read the works of Euler, Lagrange, Laplace, Legendre, Poisson, and the later English publications, without being arrested by difficulties every moment.

He is aware that the illustrious Professors of Mathematics at our Universities, supply that in their lectures which is wanting in their books; but be recollects also, from experience, that there are a great number of students throughout the three kingdoms, and especially in our colonies, who are denied the enviable advantages of attending University lectures.

In the hope of remedying this inconrenience in some degree, that is as far as his limited means permit, the Author is induced to publish a course of Algebra, assembling and connecting the materials scattered through the works of La Croix, Bourdon, Boisbertrand, Garnicr, etc. etc.

He is not so presumptuous as to beliere that this Essay is the best the subject admits of, but he will feel grateful for every candid critic, sufficiently recompensed if it leads to the production of a better work on the same subject; bis sole object being to offer something useful to his countrymen. 



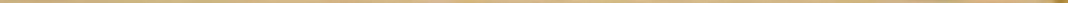

PIATE I.

1. Shell of the Sepia rugosa.

2. Shell of the Calmar. Loligo sagittata, Lam.

3. 4. Nummulites, with sections.

5. Discorbite.

6. Miliolite cour de Serpent.

7. Errotite.

8. Transverse and longitudinal sections of a Belemnite.

9. 10. 11. 12. Belemnites

13. Spirolinites.

14. Upper and under view, with a section, of the Eyrogonites medicag nula.

15. Simplegades colubrinus.

16. Turrilites compressus.

17. Baculites. vertebralis.

18. a. Spirula fragilis seu australis.

b. The siphon traversing the cliambers.

c. Section magnified. 
19. Baculites gigas.

20. Planospirites ostracinus.

21. Hippurites cornu-copia.

2.2. Belemnite.

23. Siderolites calcitrapoides.

24. Section of a Belemnite.

25. Orthoceratite.

26. Hippurite with a gutter, $c$.

27. Hippurite with a siphon.

28. Under view of the operculum of a Hippurite, shewing the two prolongations resembling a hinge.

29. Belemnite.

30. Section of an Orthoceratite with a siphon passing through the axis.

31. Hippurite, with a gutter, $a$. and a siphon, $b$.

32. Lituites Breynii, found in the marble of OEland : the shaft or straight part extends in a length equal to the depth of the Plate, gradually enlarging towards the base.

33. Hippurite, the operculum pierced with two eyes.

34. 35 . Orthoceratites with a siphon towards the edge or periphery. 


\section{PLATE II.}

1. a. b. c. d. Nautilus melo, with sections.

2. Section of Nautilus flammatus, sherring the siphon.

3. Section of Nautilus caudatus, Lister (N. major seu crassus, Rumph.) sheming the siphon passing through the chambers. 1-4th.

4. Nautilus Pompilius.

5. Nautilus auricula.

6. Scaphites Defrancii.

6. a. b. c. d. Scaphites aqualis.

7. S. Transverse and logitudinal sections of the spine of the Echinus cidaris. 
9. Noclosaria (Nautilus maplianus).

10. Amplexus coralloïdes.

11. Orthoceratites Gothlandic, 1-2.

12. Molossus gracilis.

13. Rolalite.

14. Echidnis diluvianus.

15. Raphanister campanulatum.

16. Hamites gibbosus.

17. Lenticulite.

1S. Hippuriles organicus.

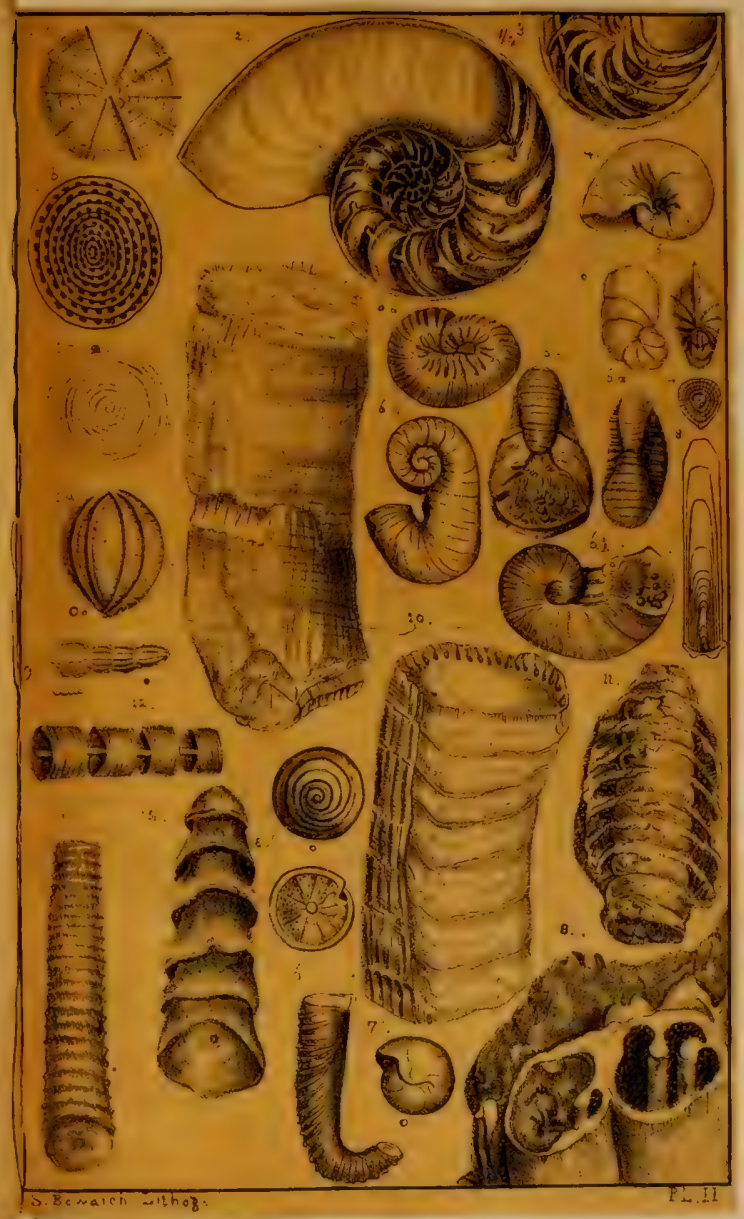




\section{PLATE III.}

1. Helix Lemani, in the $2 d$ Fresh-Water Formation.

2. Helix Menardi, in the limestone near Mans.

Second Fresh-IVater Formation.

3. Oral grain found in the silex at Longjumeau.

4. Crlindrical, channelled grains, found in opaque silex at Longjunean. They hare no resemblance to any genus now known.

5. 6. Small cylindrical stems, with a channel in the centre, and divided by transverse partitions.

7. A body in the form of a date, with sinuous channels.

8. The ear of a plant (which may be compared to certain specics of Paspalume) found in the silex at Longjumeat. 
9. Argonautiles Irvis.

10. Vaginella depressa.

11. 12. Orbulites.

13. Cristellaria ........

14. Ammonaceratites Lamarckii, 1-3d. s. siphon.

15. Ellipsolites compressus.

16. Pollontes vesicularis.

17. Arethusa corymbosa.

1S. Baculites vertebralis. Montf.

19. Conularia quadrisulcata.

20. .. teres.

21. ... quadrisulcala.

22. Telebois annulatus.

23. Tiraniles gigas.

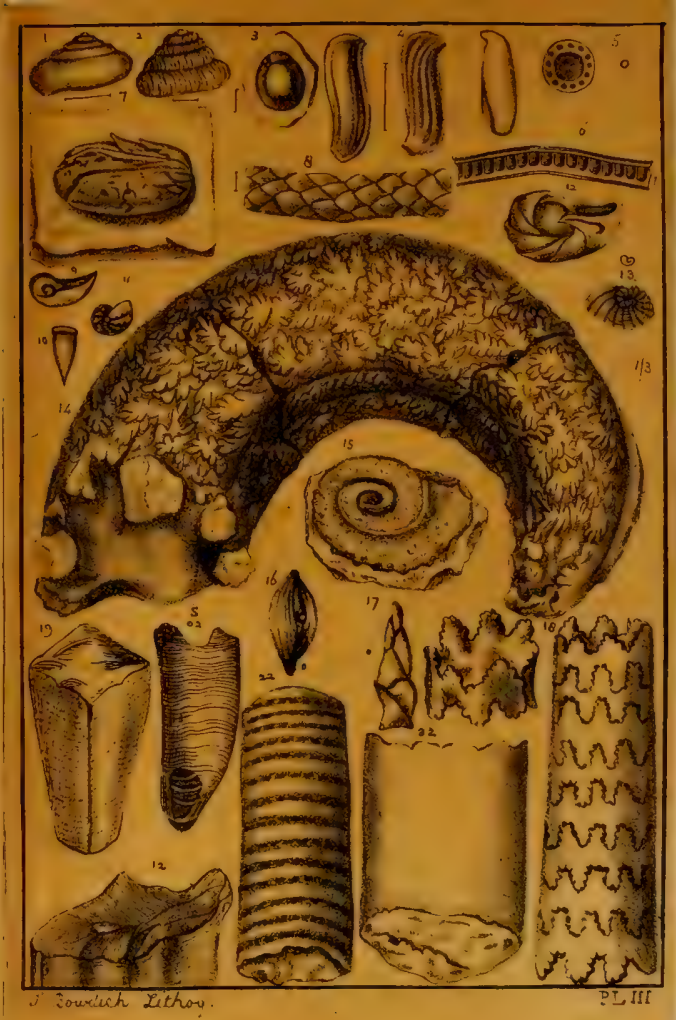




\section{PLATE IV.}

\section{First Fresh-Water Formation.}

1. Cyclostoma mumia.

2. Lymnceus strigosus.

3. .. longiscatus.

4. .. acuminatus.

5. Planorbis lens.

6. An articulated stem (with projecting papillæ), resembling the root of an Equiselum. 
1. 2. Lymuraus ovum.

3. Bulimus pusillus.

4. .. atomus.

5. Cyclostoma elegans antiquum.

6. Potamides Lamarckii.

7. S. Planorbis rotundatus.

9. ... сотиu.

10. .. Prevostinus.

11. Lymneus corneus.

12. . Fabulum.

13. .. ventricosus.

14. .. enflatus.

15. Bulinus pygnzeus.

15. . terebra.

16. Lymnceus palustris antiquus.

17. Pupa Definancit.

18. Helix Ramondi.

19. .. Desmarestina.

20. . . Cocquii.

21. . . Moroguesi.

22. . Tristani.

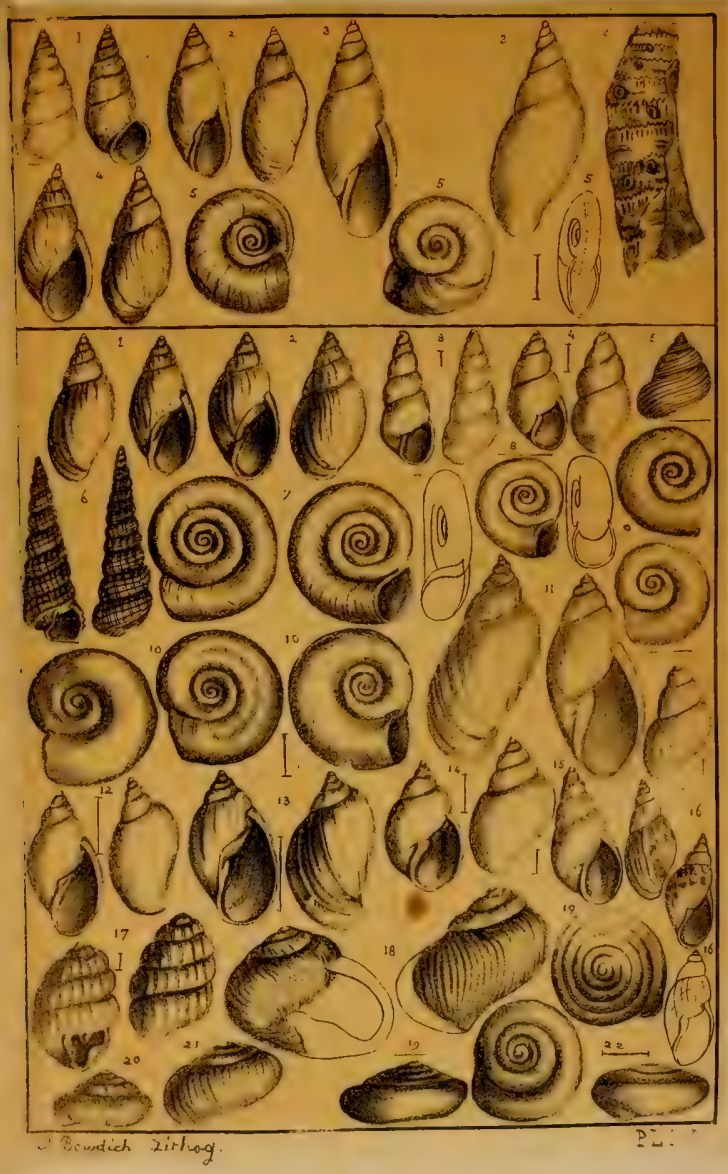




\section{PLATE V.}

1. Hyalea tricuspidata.

2. Cleodora pyramidalis.

3. Cymbulia proboscidea.

4. Parmaphora elongata.

5. Patella elongata.

6. .. cornucopia.

7. Ancylus fluviatilis.

8. Upper and under view of the Calyptrcea equestra.

9. of the Tesiacella halio lidea.

10. Fissurella (Patella Greca, List.).

11. Emarginula clypeata.

12. Under and side view of the Crepidula porcellana.

13. of the Capulus tortus.

11. Vitrina pellucida. 
15. Umbrella Indica.

16. Carinaria vitrea.

17. Dolavella.

18. Bulleea.

19. Bulle operta.

20. Infundibulum echinulatum.

21. Stomatic plymmotis

22. Stomatella imbricata.

23. Septaria seu Navicella (Patella Borbonica).

a. Back view.

b. Under ..

c. Side.

d. Operculum

24. Halyotis vulgaris.

25. Sigaretus concavus.

Some of the figures in this Plate are inadvertently reversed.

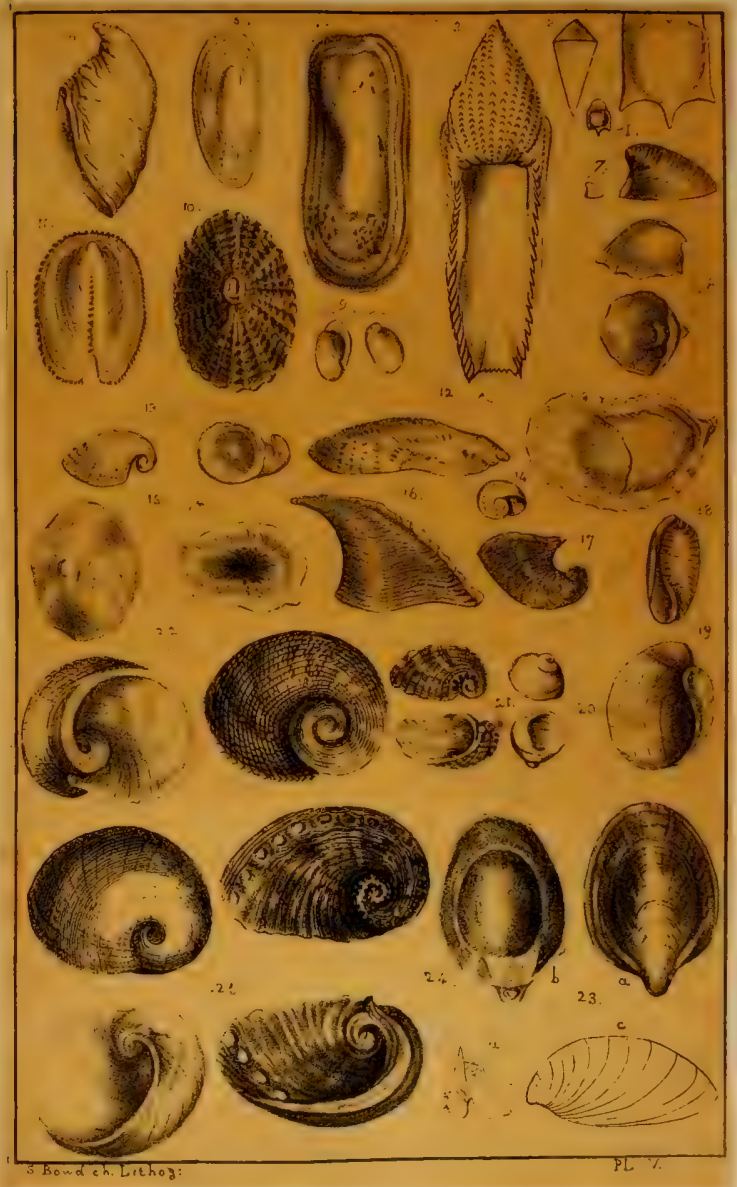




\section{PLATE VI.}

1. Iippony $x$ comucopice. Defr.

1. In profile, 1-2.

1. Shewing the support within, 1-2.

c. In profile, without the support, 1-2.

d. Seen within.

$e$. On its support, as it was found.

$f$. The support seen within.

g. Hipponyx mitrata, Defr. a recent shell, wilh its support

h. Hipponyx cornucopice, shewing the mouth.

2 Plectrophorus costatus, Feruss.

3 orbignii, Feruss.

4 Padollus scalaris, Leach.

5 Ambrette Succinea, Drap. (Amphibulima, Lam.)

t Amphibulima, Lam.

; Testacellus ambiguus, Feruss.

$\varepsilon \quad . \quad$ haliotideus, Feruss.

9 .. Maugei, Feruss.

10 Parmacella Olivierii, Feruss.

11 Helicarion Cuvierii, Feruss.

12 Lymneus siagnalis.

13. Physa N. Hollandica. 
14. Melania.

15. Mfelantho.

16. Melania amarula.

17. Melanella Dufivesnii.

18. Melanopsis.

19. Melanamona.

20. Pyrene, Lam. Mtelanatria.

21. Phasianella picta.

22. Anricula Judrea.

23. Scanabis imbrium, Leacl.

24. Carychium undulatum, Leach.

25. Conovula coniformis.

26. Achatina Vinginiana.

27. Bulimus radiatus.

28. Bulimulus trifasciatus.

99. Tomatella fasciata.

30. Helicina neritella.

31. Bulinus auris-leporis (moust.)

32. Planarbis.

33. Bulimus ovilaris.

3.. Pupa modiolinus.

35. Bulimus auris-leporis.

30 Clausilia.

5., Pupa.

38 Bulimus decollatus.

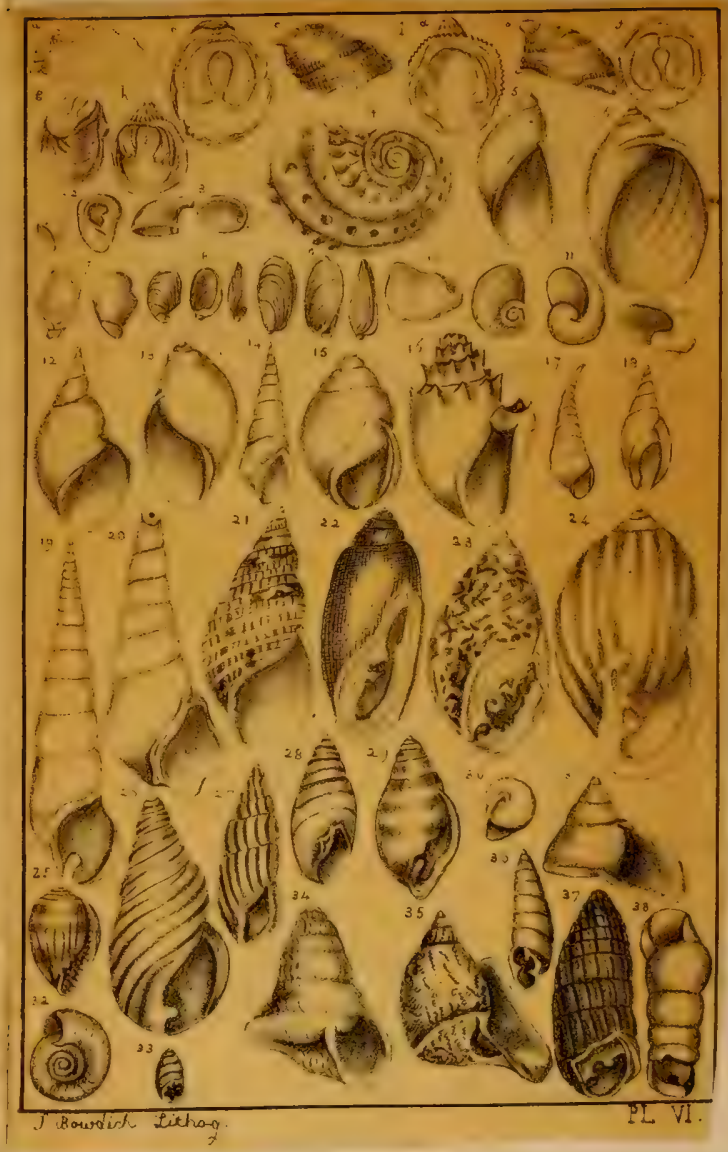




\section{PLATE VII.}

1. Helico-Limax elongata, Feruss.

2. Helix brevipes, Drap.

3. 4. Cornu giganteum, Chemn. in the young and in the adult state; one of the smaller figures represents the egg entire, and the other the animal in its shell coming out of the egg : 1-2 the natural size.

5. Bulimus patulus, Brug. (Amphibulima cucullata, Lam.)

6. ... in the young state.

7. Helix naticoides, Drap.

8. . Listeri, Feruss.

9. . ligata, Muller.

10. . deformis, Feruss. 


\section{PLATE VIII.}

1. 2. Helix pyrostoma, Feruss.

3. . . Madagascariensis, Lam.

4. Helicella lavipes, Feruss. Helix spadicea, Gunel.

5. Helix sub-dentata, Feruss.

6. . . albella, Chemn. side view.

7. . . planata, Chemn.

8. Helicella sepulcralis, Feruss.

9. Helix ochroleuca, Feruss. Helix albella, Chemn.

10. . . epistylium, Gmel.

11. .. strobilus, Feruss.

12. . nitida, Drap.

13. Cyclostoma bulimoïdes, Oliv.

14. Melania buccinoidea.

15. Cyclostoma unicolor, Oliv.

16. Bulimus labrosus, Oliv.

17. Melania costata, Oliv.

1S. Helix villosa, Drap. 


\section{PLATE IX,}

1. Ampullaria.

2. Ampullina.

3. Turbo picta, with its operculum.

4. Cirrus acutus, Somerby.

5. Aciona scalaria (Wendletrap), Leach.

6. Scalaria clatrata.

7. Trochus crenularis.

8. . agglutinans, with and without the adhering substances.

9. .. imperator (Imperator coronatus, Montf.)

10. .. calcar.

11. Solarium perspectivum.

12. Turritella. 
13. Cyclostoma mumia.

14. .. elegans.

15. Paludina fasciata (Helix vivipara, Lin.)

16. Delphinula.

17. Vermelus; Adans.

18. Euomphalus pentangulatus,
19.

20. Nerita Malaccensis, and its operculum.

21. Neritina zebra.

22. Valvata spirorbis, Drap.

23. Clithon coronata.

24. Natica.

25. Monodonta.

26. Ianthina fragilis.

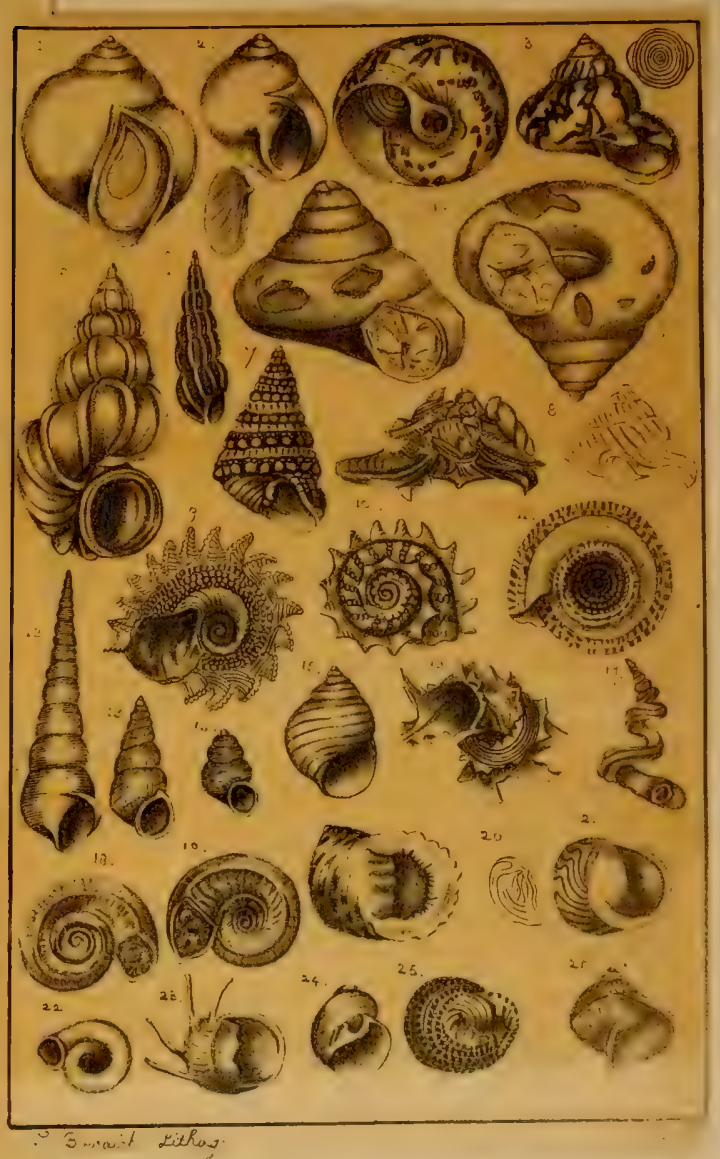




\section{PLATE X.}

1. Murex lampas.

2. . Tritonia.

3. . Brandaris.

4. Tritonia Atlantica, Montf.

5. Murex frondescens.

6. Ranella Buffonia.

7. Fusus.

8. Pyrula melongena.

9. Eburna areolata.

10. Anciliaria cinamomea.

11. Mitra. 
12. Py ramidella dolabrata.

13. Pleurotoma tigrina.

11. Fasciolaria tulipa.

15. Tubinella scolyma.

16. Rostellaria subulata.

17. Concholepas Poruviana.

18. Potamides Lamarkiti.

19. Cerithium.

20. Terebra lanceolata.

21. Buccinum undatum.

22. Doliun variegatum.

23. Nassa Thersitn.

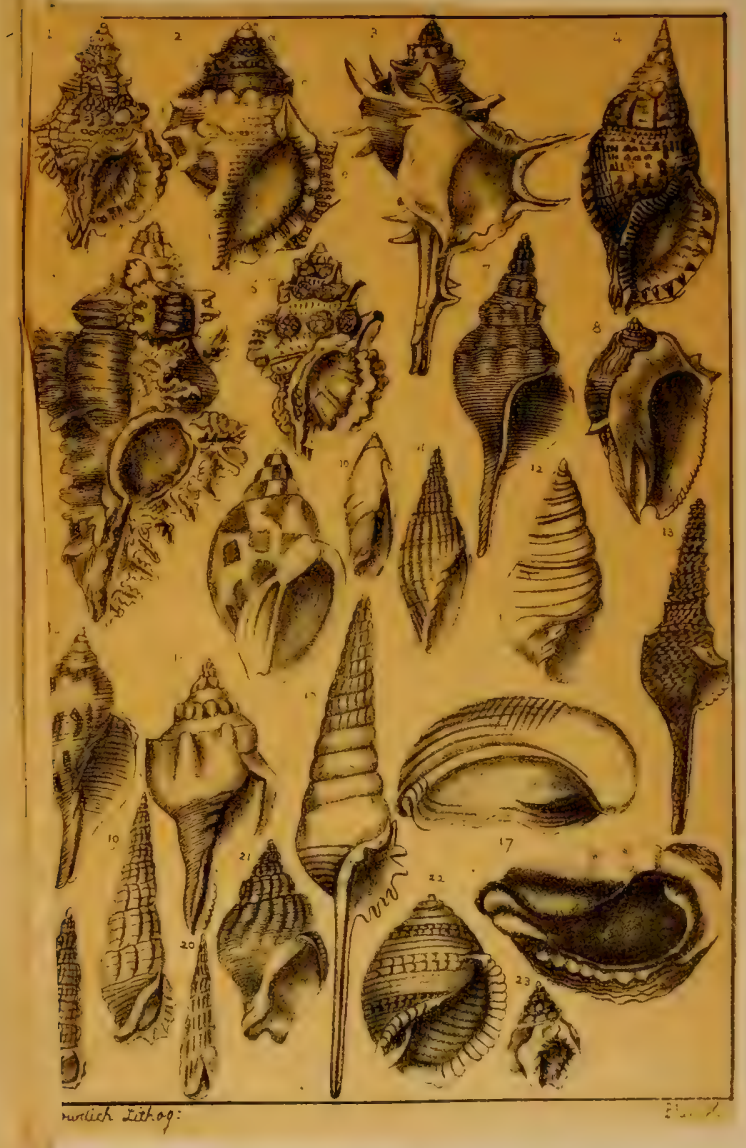




\section{PLATE XI.}

1. Harpa mutica.

2. Purpura patula.

3. Monoceros.

4. Ricinula horrida.

5. Cassidaria echinophora.

6. Cancellaria reticulata.

7. Cyprea moneta.

8. Ovula gibbosa.

9. a. Cyprea in the infant state.
b. .. ... middle .
c. .. .. adult

10. Ovula oviformis. 


\section{PIATE XII.}

1. Conalix lineatus, Swainson.

2. Voluta rugifera seu musica.

3. . volvacea.

4. . vespertilio.

5. . olla.

6. Helicina neritella.

7. Murex tubifer.

8. Bulimus zebra, Oliv.

9. Struthiolaria Lamarckii. 
10. Helix crenelata, Oliv.

11. Polyphemus Bruguireus.

12. Ampullaria (found in bituminous maslabore a mine of fossil coal.

13. .. compressed laterally; giving it an accidental, elongated form.

14. .. .. vertically; changing the form of the mouth, and

15. Turbo lugubris, Chemn. giving it the appearance of another species.

16. Section of a Pyramidella, to shew the columella.

17. Turritella.

(au jour).

18. Cyclostoma bulimoides, Oliv.

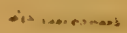




\section{PLATE XIII.}

1. Helix unidentata, Ghemn.

2. Cerithium gigas, 1-4th.

3. Achatina fulica, Lam.

4. Argonauta.

5. Aplysia.

6. Dolabella.

7. Interior mould of a Cerithium gigas, 1-4th.

8. Clavatula scabra.

9. Cyclostoma carinata, Oliv.

10. Melania marginata.

11. Helix conoüdea, Drap.

12. Pupa avena, Drap.

13. Melania cochlearella.

14. . costellata.

15. Bulimus terebraster.

16. Buccinum Barbadense, Lister.

h. The head.

- tt. .. tentacula.

m. .. mouth.

T. .. trunk.

ec. .. eyes.

f. .. foot.

o. .. operculum. 
17. Cerilhium. (Buccinum Africanum, Lister.)
$h$. The head.
u. .. tentacula.
m. .. mouth.
ee. .. eyes.
T. .. trunk.
f. .. foot.
o. .. operculum.

18. Limax phosphorescens, 1-2.

19. 20. Yetus, Adans. (Buccinum Persicum, Lister.)
$h$. The head.
ti. .. tentacula.
m. .. mouth.
ee. .. eyes.
T. .. trunk.
$k$. .. extremity of the manile, forming a sort of pipe.
nn. .. membrane accompanying the mantle.
f. A part of its enormous foot.

21. Halyotis.

h. The head.

it. .. four tentacula,

ce. .. eyes.

n. .. membrane which attaclies the lower tentacula to the hend.

t. .. two anterior extremities of the mantle, coming out of the second hole of the sbell.

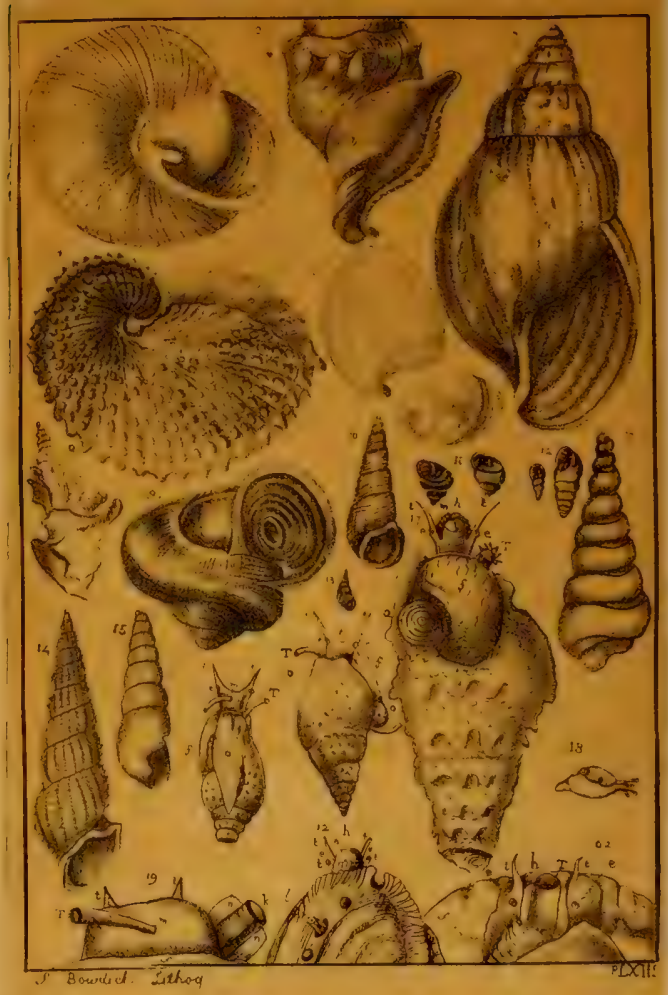


1. The hearts of the Calmar.

a. The hollow vein.

bb. .. lateral hearts.

cc. .. pulmonary arteries.

dd. The place of the branchix.

ee. .. pulmonary veins.

$f$. .. middle heart.

gg. .. aorta.

2. The heart of the Aplysia.

a. The hollow vein.

d. .. branchix.

e. The auricle and pulmonary vein.

$f$. .. heart.

g. .. arteries.

3. Spirula fragilis with its shell.

4. Tapada putris, with its shell.

5. The under side of a Patella, the head bent towards the foot.

a. The foot.

b. .. mouth.

cc. .. tentacula.

d. .. anus and orifice of generation.

e. The pericardium.

$f$. .. trunk of the branchial vein.

ggg. .. circular part of the above vein.

hh. .. branchire.

ii. .. branchial artery.

6. I Patella of the species in which the branchix are interrupted.

a. The mouth.

bb. .. tentacula.

c. .. fleshy mass.

d. .. nervous collar.

f. .. ovarium.

gg. The intestines.

h. .. branchix.

ii. .. branchial veins.

$q q$. .. oviductus.

7. Helix brevipes, with its shell.

8. Hyalea australis, with its shell secn on the side of the projecting valve.

$a$. b. $c$. The projecting points of the flat or ventral valve.

d. The dorsal valve.

ff. .. mantle coming out from the interstice between the valies, close

l. $m$... fins.

n. .. mouth.

9. Parmacella Olivieri, Cuv. opened.

a. The mouth.

bb. .. great horns.

c. .. brain.

d. .. salivary glands.

e.ff. . o organs of generation.

g. .. bag for the colouring liquid.

l. ... stomach.

ii. The retracting muscles.

$k k$. .. liver.

$l$.. lungs.

m. .. auricle.

n. .. heart.

$o$. .. intestine.

z. .. mantle turned back.

10. Calmar (Sepia Loligo).

a. The head.

b. ... eyes.

(i. .. feet.

d. .. arms.

e. The funnel.

$f$. .. abdomen.

s. .. fins. 
11. Brain of the Polypus;

a. The ring round the ceso- $\begin{aligned} & \text { del. The lateral ganglions. } \\ & \text { phagus. }\end{aligned}$
$\begin{array}{lll}\text { e. .. abdominal plexus. } \\ \text { cc. .. brain. }\end{array}$

cc. .. optical gang

a. The ring round the cesopliagus.

b. .. brain.

e. .. abdominal ganglion.

12. The animal and shell of the IIelico-Limax elongata.

13. Janthina penicephala, with its vesicular appendage (spuma cartilsginea) attached to the posterior part of the foot.

14. Aplysia.

a. The head.

b. .. inferior tentacula.

c. .. superior

d. .. eyes.

e. .. mantle.

$f$. .. operculum of the branchix.

15. The female Sigaretus seen underneath: the head and foot a little bent, to shew the entrance of the branchial cavity.
a. The notch.
I b. The anus.

16. The male Sigaretus seen underneath.
a. The notch.
bb. .. tentacula
d. The anterior part of the foot
transrersely.
$e .$. organs of generation:
.$f$. .. edges of the mantle.

17. Carinaria Mediterranea.

18. Pleclophorus with its shell.

19. The female Vivipara taken out of its shell.

a. The foot partly folded in two.

b. .. operculum attached to the posterior part.

c. .. head with the tentacula and trunk.

d. .. little siphon prolonged under the right tentaculum.

e. .. lateral membrane of the left side.

f. .. edge of the mantle.

g. A small portion of the branchix shering itself from underncath.

h. The orifice of the womb and anus.

20. Ilalyotis, drawn from the living animal, with all its ornaments.

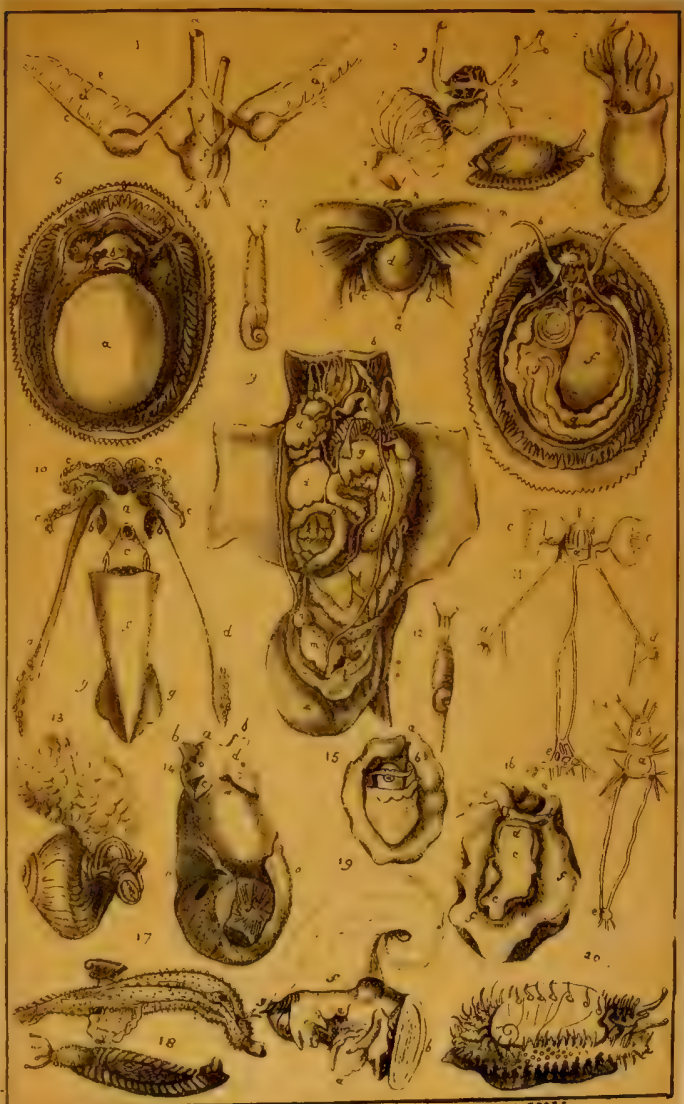

PLXIV

s Bowduch Lithoy 
1. The Argonauta argo sailing.

2. Ocythoë Cranchii, Leach, sitting within the shell.

3. Clio Borealis.

a. The body.

b. .. viscera seen through the common coverings.

cc. .. tubercles of the head, and the holes into which the three tentacula on each side retire.

dd. .. branchix and fins.

4. Pneumodermon, front view.
a. The body.
b. .. head.
c. .. mouth.
dd. .. lips.
$e$. The chin or pointed fleshy appen- dage.
ff. .. fins.
g. .. branchix.
$h$. .. trunk of the branchial vein.

5. Pneumodemon, with the skin divided to shew the position of the pericardium and fleshy tunic.

i. The auricle.

k. .. pericardium.

ll. .. fleshy tunic with its longitudinal fibres.

6. The Eolis, placed obliquely, shewing the belly and right side.

7. Scyllea pelagica, on the right side.

$H H$. The under surface of the foot hollowed into a deep furow, by which it suspends itself.

G. .. mouth.

$A A$. .. two tentacula.

$B C$. Two pair of memlranous flexible These and the back bear the wings.

D. A crest on the tail.

Jranchix in the form of little fi-

$E$. The orifice of generation.

F. .. orifice of the anus. 
3. Scylleza pclagica secu on the side of the belly.

9. Scyllex pelagica suspended to a branch of the Fucus natans.

10. Phyllidia trilineata seen on the upper side. aa. The indentations for the upper tentacula.
b. .. .. of the anus.

11. An upper tentaculun magnified.

12. Phyllidia trilineata seen undermeath. ac. The inferior tentacula, between which is the mouth.

b. .. branchix of the left side.

c. .. orifice of generation.

13. A Limax seen on the right side, the tentacula half developed. aa. The great tentacula.

bb. .. smaller

c. .. mouth, between which and the small tentacula are seen the papilla of the upper lip.

dd. .. foot

e. .. posterior point of the back, whence issues the mucosity by which it suspends itself.

f. .. mantle.

g. .. orifice for respiration.

h. .. .. generation.

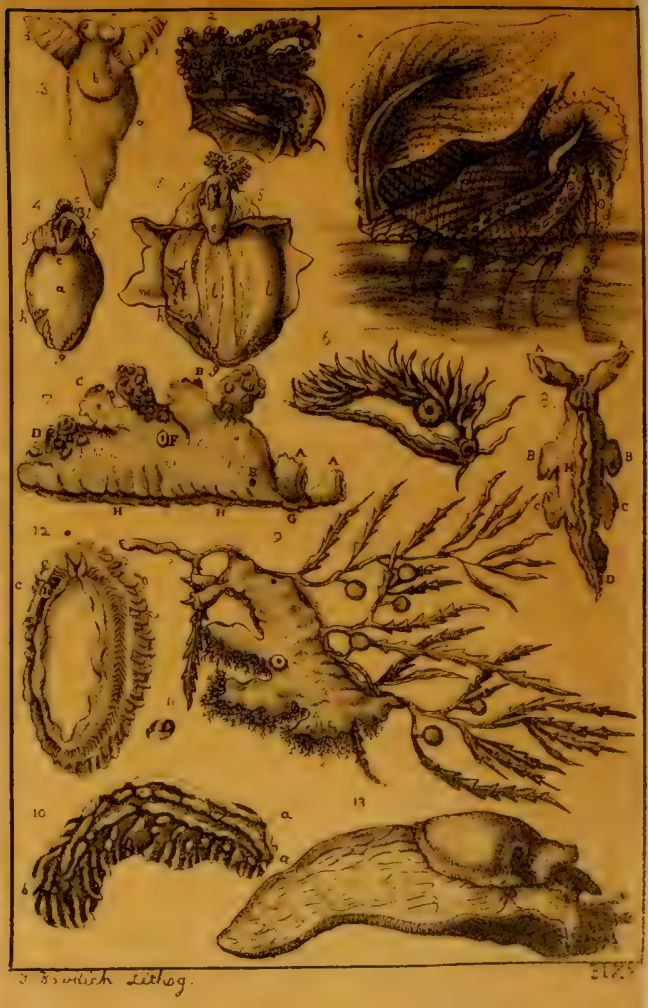




\section{PLATE XVI.}

1. Bulla aperta entire, seen on the back.

$a$. The fleshy plate which covers the front of the body, or the tentacular disk

c. .. part containing the shell.

2. Bulla aperta on the right side, with the ventral fleshy plate separated from the dorsal, to shew what is between them.

a. The tentacular disk.

b. .. plate serving as a foot. $\left\{\begin{array}{l}e . \text { The anus. } \\ f .\end{array}\right.$

3. Bulla aperta, seen underneath.

$b$. The plate serving as a foot.

c. .. part containing the shell:

d. A part of the branchix.

4. Bulla aperta, partly dissected.
a. The stomach.
b. .. oesophagus.
d. .. branchiæ.
e. The heart.
f. .. liver.
g. .. intestine.
h. .. testicle. organ and oviductus.

5. The tongue of the Bulla aperta greatly magnified.

6. Helix ponatia, taken from its shell, and seen on the left side: a large portion of the corering of the pulnonary cavity has been taken away to shew its position; also the teguments of the remainder of the spire, to shew the situation of the heart, the bag of viscous matter, etc.

a. The large right tentaculum $\mid k$. The hole for respiration seen half developed.

b. .. hole whence the left tentaculum issues.

c. . hole for the small tentaculum of the same side.

dd. . two lobes of the veil or upper lip.

cee... edges of the foot.

$f f$. Two of the lobes placed under the collar.

gg. The pad of the collar.

$h h$. . place where the cover- ing of the pulmonary cavily has been cut away.
i. .. rectum. within the pulmonary cavity.

l. .. diaphragm.

$m n$. .. heart and auricle in their proper place in the open pericardium.

o. .. commencement of the great artery of the spire.

bag of viscous matter.

. first part of the intestine.

- second part.

. lobes of the liver. 
7. Capulus, Mont. (Patella Hungarica, Lin.) detached from its shell, and
seen on one side. The foot.

b. A sort of ruff which this foot $d$. The trunk. sort of ruff which this foot ee. .. tentacula.
has in front.

c. The muscle which attaches the foot to the shell.

f. .. liver and a part of the viscera,

8. Onchidium, under view. which occupy the bottom
of the shell.

9. Parmacella, seen on the back: the shell has been taken away, and only
its impression remains.

10. The horned Planorbis, with its shell.

11. The animal of the Cyproea.

12. .. .. $\quad$.. Conus.

13. Emarginula entire.

14. Nerrous system of the Fissurella.

15. Animal of the Crepidula, detached from its shell, scen above; the abdomen and branchial cavity in their natural position.

16. Shell of the Crepidula seen underneath.

c. Plate which retains the point of the abdomen.

17. Animal of the Crepidula, detached from its shell, and the upper parti-, tion of its branchial cavity turned back to shery the branchix.

18. Testacellus halyotideus, animal and shell.

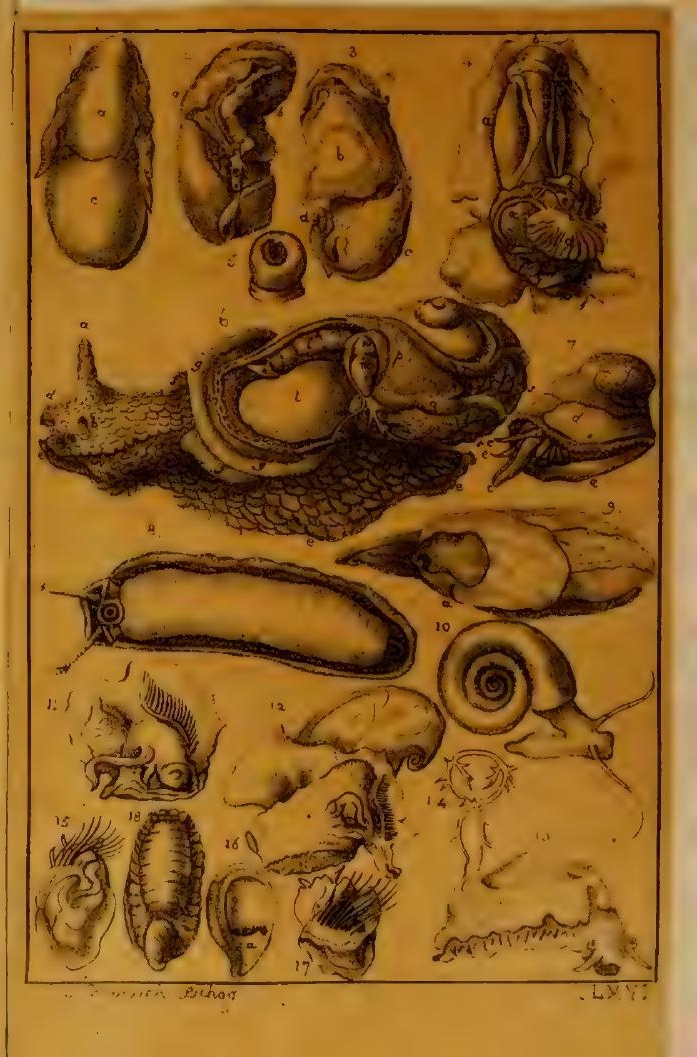




\section{PIATE XVII.}

1. Scalaria.

2. The female Frivipara taken out of its shell, and the branchial carity opened.
a. The foot folded in trro.
b. .. operculum attached to its
posterior part.
c. .. head, with the tentacula
d. .. litule siphon prolonged under the right tenta- culum.
e. . laweral membrane of the left side.
f. .. edge of the mantle.
$g$. .. branchix.
$h$. . womb swelled by the foe-
tus within.
h. The orifice of the womb.
h. .. part situated under the spire.
$i$. .. anus.
l. . canal of viscous matter.
$m$. .. projecting line, forming a se- mi-canal, which terminales at the siphon $d$.
$n$. .. heart and its auricle.
o. .. parts of the lirer and intestine.

3. Trochus. (Cochlea sublivida, Lis.)

$h$. The head.

tt. .. tentacula.

ec. .. eyes.

$\mid \begin{array}{lll}p . & \text { The languelte. } \\ P . & \ldots & \text { foot. } \\ o . & \ldots & \text { operculum. }\end{array}$

4. Do. seen underneath.
$f$. The foot.
$m$. The mouth.

5. Animal of the Trochus phamnius, taken out of its shell, with its opreculum.

6. 7. .. . . Turbo littoreus.

8.9.10... .. Turbo chrysostomus.

11. .. . Nerita canrena, taken out of its shell.

12. . . . Nerita exuvia, with its operculum.

1:. .. . . Trochus, Gualt. 

1. Voluta Elhiopica, 1.2.

2. Voluta.

3. Cerithium.

4. squila.

2. Fusus.

6. Murcx decussalus.

7. Cassis glaucres.

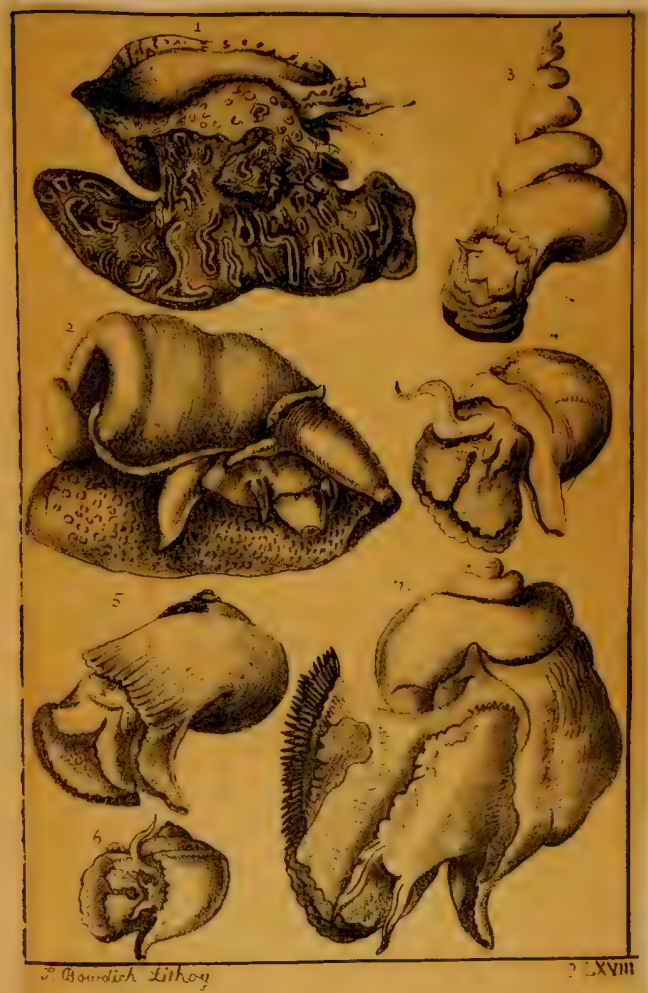




\section{PLATE XIX:}

1. Strombus pugilis.

2. Murex saxatilis.

3. Halyolis vulgaris, its shell tahen away, seen on the back, and the edges of the branchial cavity put asunder.

A. The large muscle which attaches the animal to the shell.

$a$. The anus.

bb. .. branchix.

c. The viscous organ.

d. .. heart in its pericardiun.

4. Halyotis, etc. the pericardium and branchial cavity opened.

A. The large muscles above. $d$. The heart.

a. .. anus.

bb. .. branchix.

c. ... viscous organ.

e. .. right auricle.

f. .. left auricle.

$g$. . hent surrounding the rectum.

ii. . branchial arteries.

5. The heart and large vessels magnified.

$a, i$. As the preceding figure.

h. The right branchial rein. 
i. Fissurella cutire, covered with its shell, which is set in the edges of its mantlc.

$-\quad \ldots \quad$ open.

a. The disk of the foot.

bb. . circular muscle which joins it to the shell, and which has been cut.

b. A portion of this muscle remaining with the man-

cc. The mantle thrown back, and

seen on the under side.

d. .. hole with which it is

pierced.

ce. .. branchis.

f. ... anus.

g. The heart.

hh. .. auricles.

ii. .. intestine.

k. .. aesophagus.

l. .. pharynx.

mm. .. salivary glands.

nn. .. lateral ganglions of the braiu

o. .. exiremity of the tongue.

pp. .. liver.

q. .. ovarium.

8. Vermeius, Adanson.

c. The tentacula.

r. .. eyes.

$F$. Cylindrical filaments.

o. Operculum.

M. Mantle.

A. A perture by which the animal breathes.

9. The same animal secu underncalh.

p. The foot put on one side, to make it more apparent.

B. The mouth.

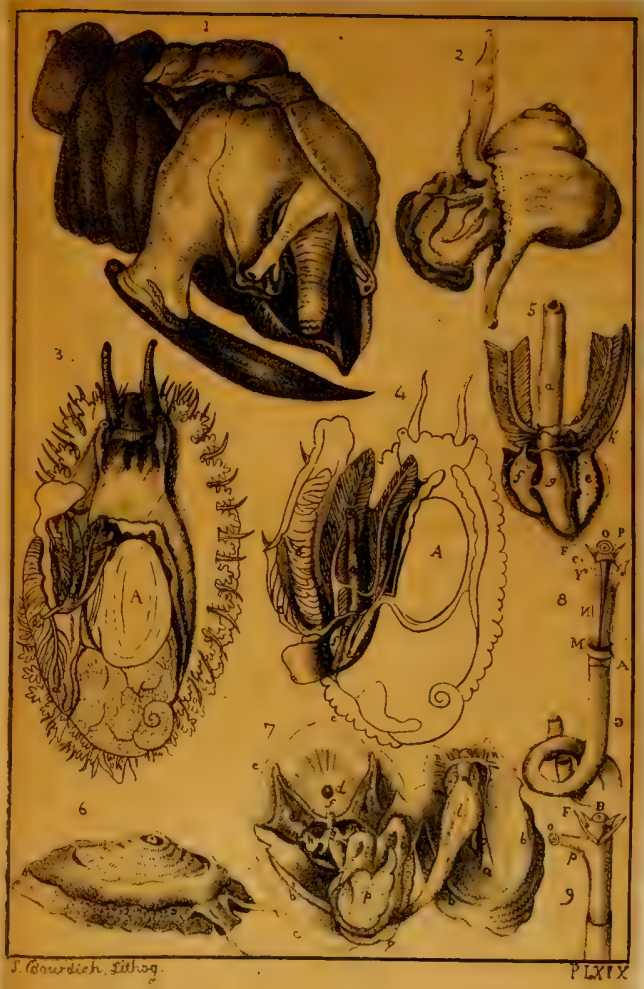









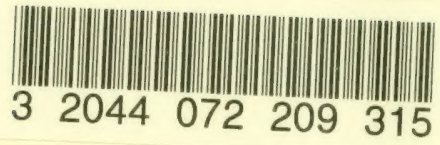


